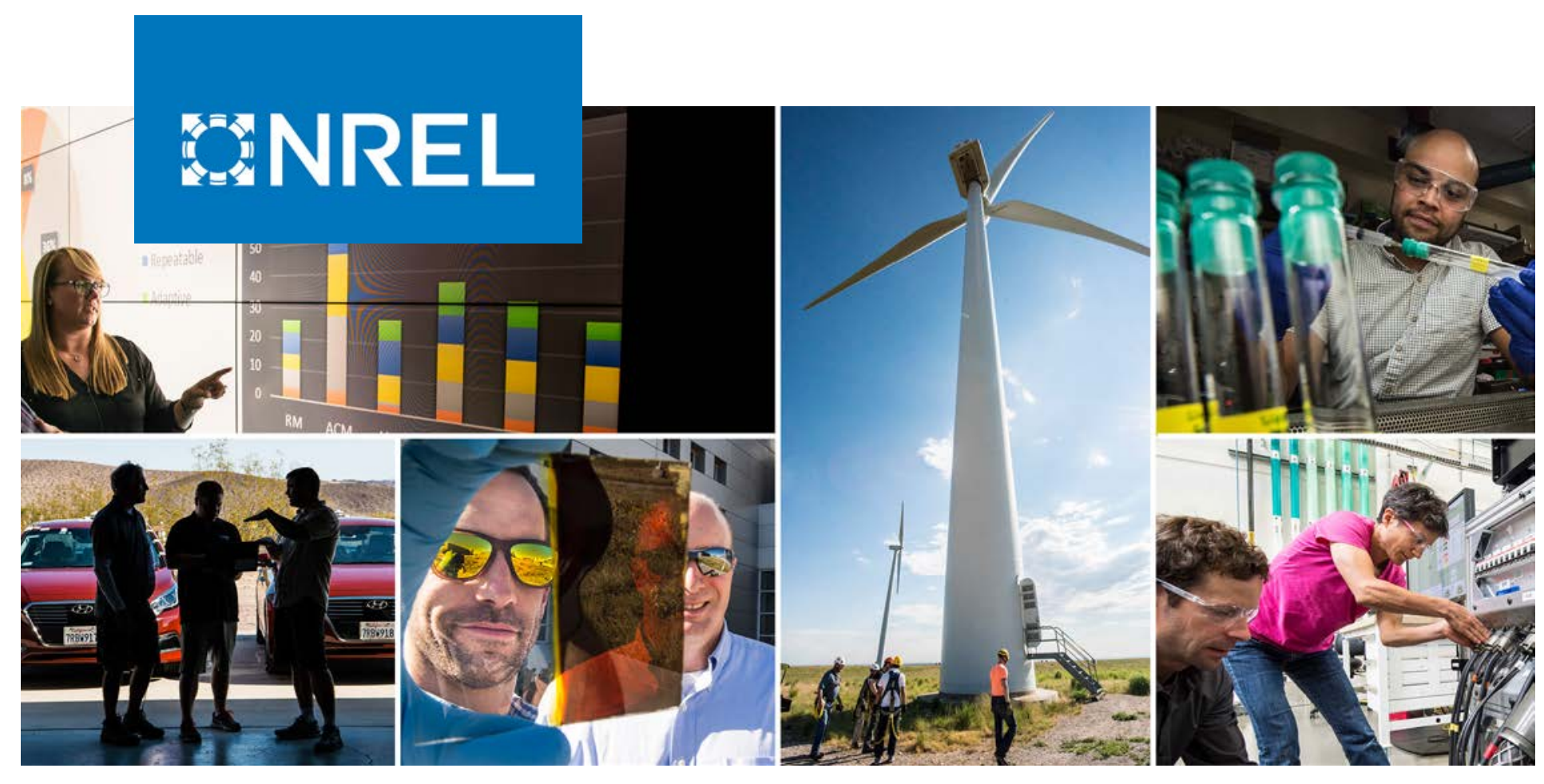

\title{
U.S. Solar Photovoltaic System Cost Benchmark: Q1 2018
}

Ran Fu, David Feldman, and Robert Margolis

National Renewable Energy Laboratory

NREL is a national laboratory of the U.S. Department of Energy

Office of Energy Efficiency \& Renewable Energy

Operated by the Alliance for Sustainable Energy, LLC

This report is available at no cost from the National Renewable Energy Laboratory (NREL) at www.nrel.gov/publications.

\section{Technical Report}

NREL/TP-6A20-72399

November 2018 


\section{GNREL}

\section{U.S. Solar Photovoltaic System Cost Benchmark: Q1 2018}

Ran Fu, David Feldman, and Robert Margolis

National Renewable Energy Laboratory

\section{Suggested Citation}

Fu, Ran, David Feldman, and Robert Margolis. 2018. U.S. Solar Photovoltaic System Cost Benchmark: Q1 2018. Golden, CO: National Renewable Energy Laboratory. NREL/TP-6A20-72399. https://www.nrel.gov/docs/fy19osti/72399.pdf.

NREL is a national laboratory of the U.S. Department of Energy Office of Energy Efficiency \& Renewable Energy Operated by the Alliance for Sustainable Energy, LLC

This report is available at no cost from the National Renewable Energy Laboratory (NREL) at www.nrel.gov/publications.

Contract No. DE-AC36-08GO28308
Technical Report NREL/TP-6A20-72399

November 2018

National Renewable Energy Laboratory 15013 Denver West Parkway Golden, CO 80401

303-275-3000 • www.nrel.gov 


\section{NOTICE}

This work was authored by the National Renewable Energy Laboratory, operated by Alliance for Sustainable Energy, LLC, for the U.S. Department of Energy (DOE) under Contract No. DE-AC36-08G028308. Funding provided by the U.S. Department of Energy Office of Energy Efficiency and Renewable Energy Solar Energy Technologies Office. The views expressed herein do not necessarily represent the views of the DOE or the U.S. Government.

This report is available at no cost from the National Renewable Energy Laboratory (NREL) at www.nrel.gov/publications.

U.S. Department of Energy (DOE) reports produced after 1991 and a growing number of pre-1991 documents are available free via www.OSTI.gov.

Cover Photos by Dennis Schroeder: (clockwise, left to right) NREL 51934, NREL 45897, NREL 42160, NREL 45891, NREL 48097, NREL 46526.

NREL prints on paper that contains recycled content. 


\section{Acknowledgments}

This work was authored by the National Renewable Energy Laboratory, operated by Alliance for Sustainable Energy, LLC, for the U.S. Department of Energy (DOE) under Contract No. DEAC36-08GO28308. Funding provided by U.S. Department of Energy Office of Energy

Efficiency and Renewable Energy Solar Energy Technologies Office. The views expressed in the article do not necessarily represent the views of the DOE or the U.S. Government. The U.S.

Government retains and the publisher, by accepting the article for publication, acknowledges that the U.S. Government retains a nonexclusive, paid-up, irrevocable, worldwide license to publish or reproduce the published form of this work, or allow others to do so, for U.S. Government purposes. 


\section{List of Acronyms}

$\mathrm{AC}$

BOS

DC

EPC

FICA

GW

ILR

ITC

LCOE

MACRS

MLPE

NEC

NEM

NREL

O\&M

PERC

PII

PV

Q

R\&D

SAM

SG\&A

TPO

USD

$\mathrm{Vdc}$

Wac

$\mathrm{Wdc}$ alternating current

balance of system

direct current

engineering, procurement, and construction

Federal Insurance Contributions Act

gigawatt

inverter loading ratio

investment tax credit

levelized cost of energy

Modified Accelerated Cost Recovery System

module-level power electronics

National Electric Code

net energy metering

National Renewable Energy Laboratory

operation and maintenance

passivated emitter and rear cells

permitting, inspection, and interconnection

photovoltaic(s)

quarter

research and development

System Advisor Model

sales, general, and administrative

third party ownership

U.S. dollars

volts direct current

watts alternating current

watts direct current 


\section{Executive Summary}

This report benchmarks U.S. solar photovoltaic (PV) system installed costs as of the first quarter of 2018 (Q1 2018). We use a bottom-up method, accounting for all system and projectdevelopment costs incurred during the installation to model the costs for residential, commercial, and utility-scale systems. In general, we attempt to model the typical installation techniques and business operations from an installed-cost perspective. Costs are represented from the perspective of the developer/installer; thus, all hardware costs represent the price at which components are purchased by the developer/installer, not accounting for preexisting supply agreements or other contracts. Importantly, the benchmark also represents the sales price paid to the installer; therefore, it includes profit in the cost of the hardware, ${ }^{1}$ along with the profit the installer/developer receives, as a separate cost category. However, it does not include any additional net profit, such as a developer fee or price gross-up, which is common in the marketplace. We adopt this approach owing to the wide variation in developer profits in all three sectors, where project pricing is highly dependent on region and project specifics such as local retail electricity rate structures, local rebate and incentive structures, competitive environment, and overall project or deal structures. Finally, our benchmarks are national averages weighted by state installed capacities. Table ES-1 summarizes the first-order benchmark assumptions.

Table ES-1. Benchmark Assumptions

\begin{tabular}{lll}
\hline Unit & Description & \\
\hline Values & 2018 U.S. dollars (USD) ${ }^{2}$. & \\
\hline System Sizes & $\begin{array}{l}\text { In direct current (DC) terms; inverter prices are converted by DC-to-alternating } \\
\text { current (AC) ratios }\end{array}$ & Size Range \\
\hline \hline PV Sector & Description & $3-10 \mathrm{~kW}$ \\
\hline Residential & Residential rooftop systems & $10 \mathrm{~kW}-2 \mathrm{MW}$ \\
\hline Commercial & Commercial rooftop systems, ballasted racking & $>2 \mathrm{MW}$ \\
\hline Utility-Scale & Ground-mounted systems, fixed-tilt and one-axis tracker & \\
\hline
\end{tabular}

Based on our bottom-up modeling, the Q1 2018 PV cost benchmarks are:

- $\$ 2.70$ per watt DC (Wdc) (or \$3.11 per watt AC [Wac]) for residential systems

- $\$ 1.83 / \mathrm{Wdc}$ (or $\$ 2.10 / \mathrm{Wac}$ ) for commercial systems

\footnotetext{
${ }^{1}$ Profit is one of the differentiators between "cost" (aggregated expenses incurred by a developer/installer to build a system) and "price" (what the end user pays for a system).

2 The dollar per watt total cost value is benchmarked as three significant figures, because the model inputs, such as module and inverter prices, use three significant figures.
} 
- $\$ 1.06 / \mathrm{Wdc}$ (or $\$ 1.44 / \mathrm{Wac}$ ) for fixed-tilt utility-scale systems

- $\$ 1.13 / \mathrm{Wdc}$ (or $\$ 1.47 / \mathrm{Wac}$ ) for one-axis-tracking utility-scale systems. ${ }^{3}$

Figure ES-1 puts our Q1 2018 benchmark results in context with the results of previous NREL benchmarking analyses. When comparing the results across this period, it is important to note the following:

1. Values are inflation adjusted using the Consumer Price Index (2018). Thus, historical values from our models are adjusted and presented as real USD instead of nominal USD.

2. Cost categories are aggregated for comparison purposes. "Soft Costs - Others" represents permitting, inspection, and interconnection (PII); land acquisition; sales tax; and engineering, procurement, and construction (EPC)/developer overhead and net profit.

3. A comparison of Q1 2017 and Q1 2018 is presented in Table ES-2.

Overall, modeled PV installed costs across the three sectors have experienced different recent changes. The inflation-adjusted system cost differences between Q1 2017 and Q1 2018 are a $\$ 0.14 / \mathrm{Wdc}$ decrease for residential PV, a $\$ 0.05 / \mathrm{Wdc}$ decrease for commercial PV, a $\$ 0.02 / \mathrm{Wdc}$ increase for fixed-tilt utility-scale PV, and a $\$ 0.01 / \mathrm{Wdc}$ increase for one-axis tracker utility-scale PV. Table ES-2 shows the benchmarked values for all three sectors and drivers of cost decreases and increases.

\footnotetext{
${ }^{3}$ This year, we use the DC-to-AC ratio 1.36 for fixed-tilt and 1.30 for one-axis-tracking utility-scale PV systems (see Section 2.5).
} 


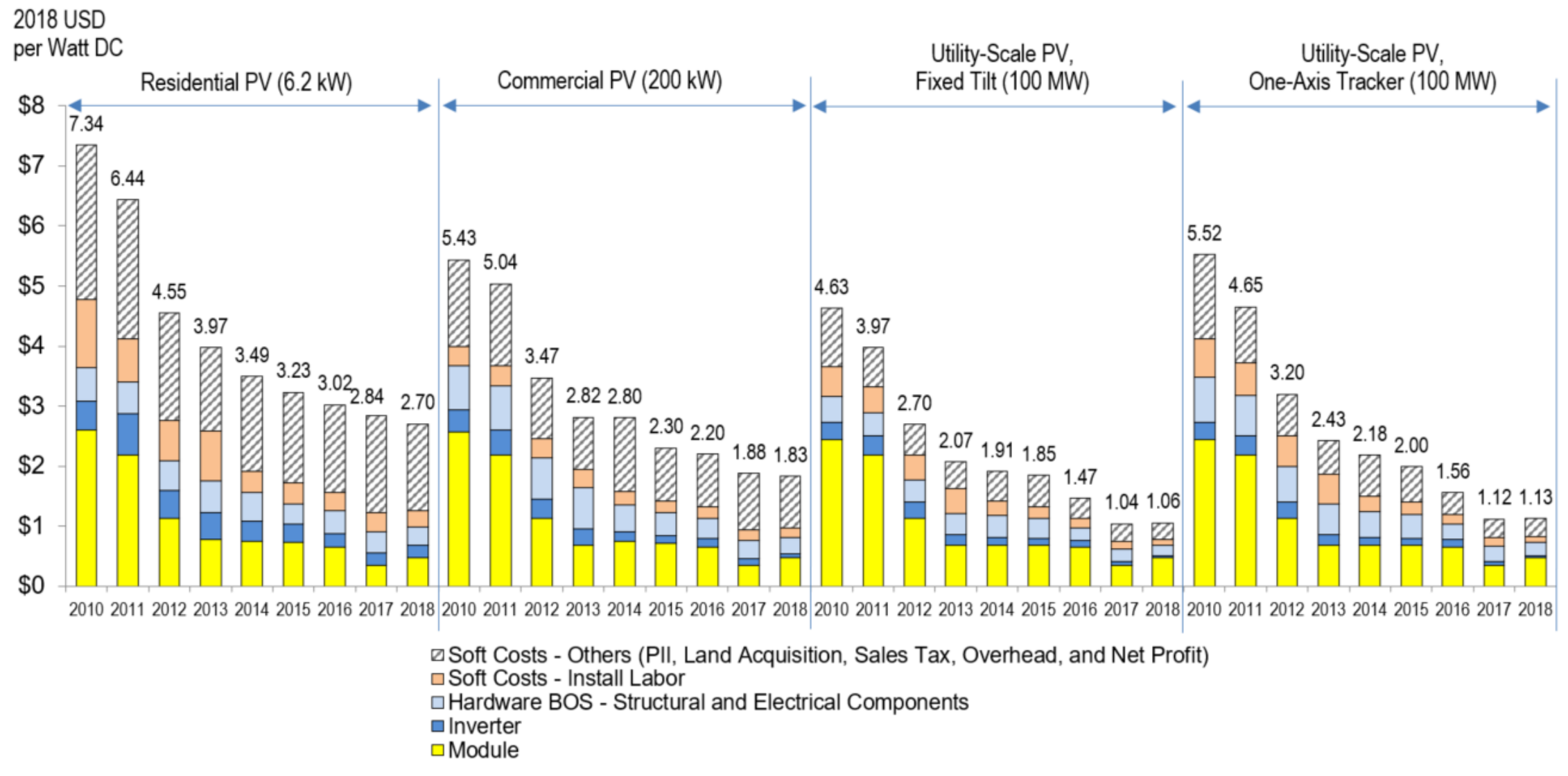

Figure ES-1. NREL PV system cost benchmark summary (inflation adjusted), 2010-2018 
Table ES-2. Comparison of Q1 2017 and Q1 2018 PV System Cost Benchmarks

\begin{tabular}{|c|c|c|c|}
\hline Sector & Residential PV & Commercial PV & $\begin{array}{l}\text { Utility-Scale PV, One- } \\
\text { Axis Tracking }\end{array}$ \\
\hline $\begin{array}{l}\text { Q1 } 2017 \\
\text { Benchmarks in } \\
2017 \text { USD/Wdc }\end{array}$ & $\$ 2.80$ & $\$ 1.85$ & $\$ 1.11$ \\
\hline $\begin{array}{l}\text { Q1 } 2017 \\
\text { Benchmarks in } \\
2018 \text { USD/Wdc }\end{array}$ & $\$ 2.84$ & $\$ 1.88$ & $\$ 1.12$ \\
\hline $\begin{array}{l}\text { Q1 } 2018 \\
\text { Benchmarks in } \\
2018 \text { USD/Wdc }\end{array}$ & $\$ 2.70$ & $\$ 1.83$ & $\$ 1.13$ \\
\hline $\begin{array}{l}\text { Drivers of Cost } \\
\text { Decrease }\end{array}$ & $\begin{array}{ll}\text { - } & \text { Higher module } \\
\text { - } & \text { Lowiciency } \\
\text { cower structural BOS } & \text { commodity price } \\
\text { - } & \text { Lower electrical BOS } \\
\text { commodity price } \\
\text { - } & \text { Higher labor } \\
\text { productivity } \\
\text { - } \quad \text { Lower supply chain } \\
\text { costs } \\
\text { - Decrease in higher- } \\
\text { cost module inventory } \\
\text { - Higher small installer } \\
\text { market share } \\
\text { - Lower permitting cost }\end{array}$ & $\begin{array}{ll}\text { - } & \text { Lower inverter } \\
\text { price } \\
\text { - } & \text { Higher module } \\
\text { efficiency } \\
\text { - } \quad \text { Smaller developer } \\
\text { team } \\
\text { - } \quad \text { Lower permitting } \\
\text { and } \\
\text { interconnection } \\
\text { costs }\end{array}$ & $\begin{array}{ll}\text { - } & \text { Lower inverter price } \\
\text { - } & \text { Higher module } \\
\text { efficiency } & \text { Optimized design } \\
\text { coefficients for wind } \\
\text { loads } \\
\text { - } 1,500 \mathrm{Vdc} \text { to replace } \\
1,000 \mathrm{Vdc} \\
\text { - } \quad \text { Lower developer } \\
\text { overhead }\end{array}$ \\
\hline $\begin{array}{l}\text { Drivers of Cost } \\
\text { Increase }\end{array}$ & $\begin{array}{l}\text { Higher mixed inverter } \\
\text { price due to higher } \\
\text { advanced inverter } \\
\text { adoption } \\
\text { - Higher module price } \\
\text { - Higher labor wages }\end{array}$ & $\begin{array}{l}\text { - Higher module } \\
\text { price } \\
\text { - Higher labor } \\
\text { wages }\end{array}$ & $\begin{array}{ll}\text { - } & \text { Higher module price } \\
\text { - } & \text { Higher labor wages } \\
\text { - } & \text { Higher steel prices }\end{array}$ \\
\hline
\end{tabular}


As Figure ES-1 shows, hardware cost did not experience substantial cost reductions in Q1 2018 owing to an increase in U.S. module prices. This has changed the trend of percentage of nonhardware, or "soft," costs. ${ }^{4}$ Figure ES-2 shows the contribution from soft costs. ${ }^{5}$ Soft costs and hardware costs also interact with each other. For instance, module efficiency improvements have reduced the number of modules required to construct a system of a given size, thus reducing hardware costs. This trend has also reduced soft costs from direct labor and related installation overhead.

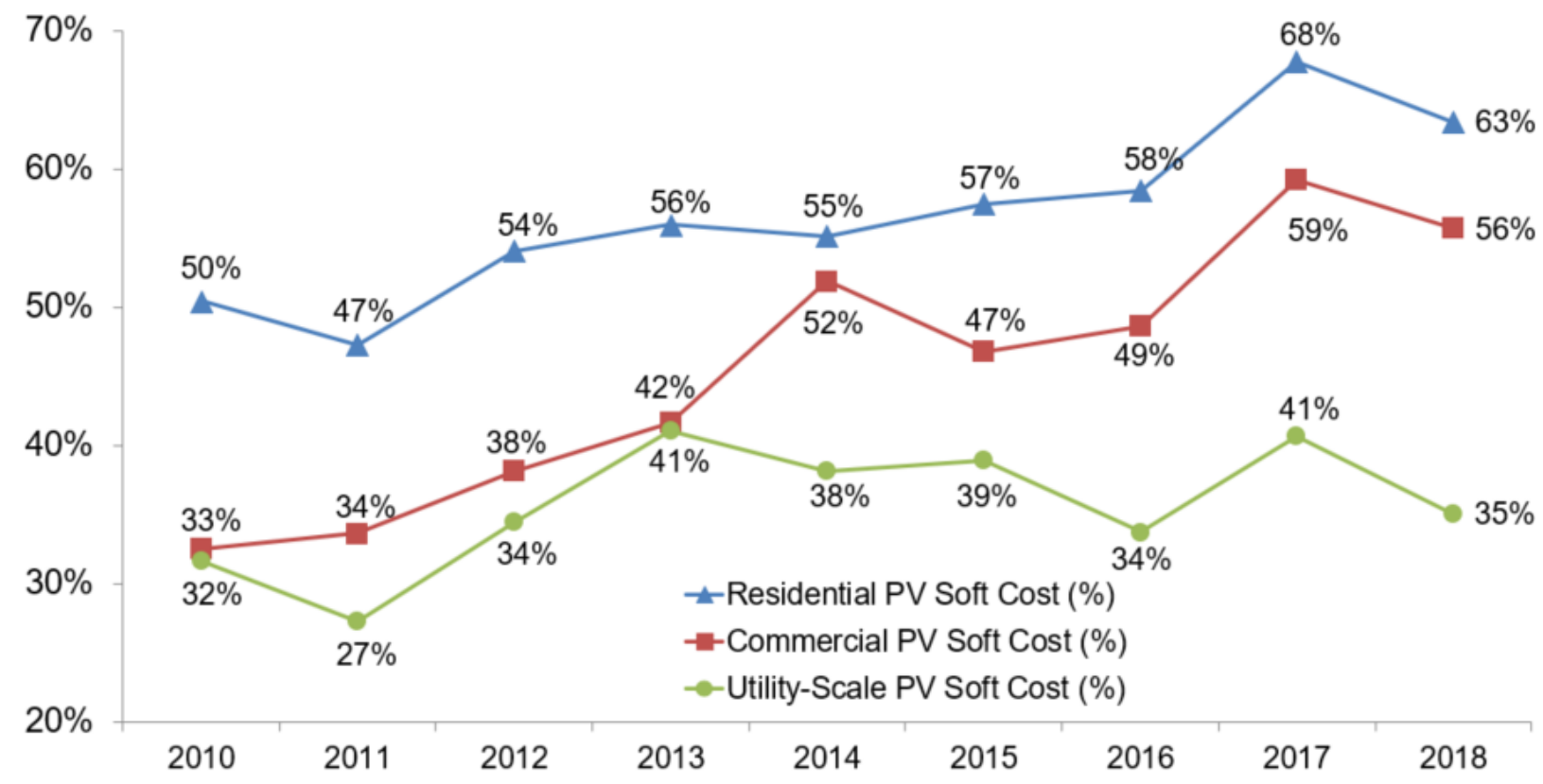

Figure ES-2. Modeled trend of soft cost as a proportion of total cost by sector, 2010-2018

Our bottom-up system cost models enable us to investigate regional variations, system configurations (such as module-level power electronics [MLPE] vs. non-MLPE, fixed-tilt vs. one-axis tracker, and small vs. large system size), and business structures (such as installer vs. integrator, and EPC vs. developer). Different scenarios result in different costs, so consistent comparisons can only be made when cost scenarios are aligned.

Finally, the changes in installed cost - along with improvements in operation, system design, and technology - have resulted in changes in the cost of electricity (Figure ES-3). U.S. residential and commercial PV systems are 89\% and 91\% toward achieving the U.S. Department of Energy Solar Energy Technologies Office's (SETO’s) 2020 electricity price targets, and U.S. utility-scale PV systems have achieved their 2020 SETO target 3 years early.

\footnotetext{
${ }^{4}$ Soft cost $=$ total cost - hardware (module, inverter, structural and electrical BOS) cost.

${ }^{5}$ An increasing soft cost proportion in Figure ES-2 indicates soft costs declined more slowly than did hardware costs; it does not indicate soft costs increased on an absolute basis.
} 


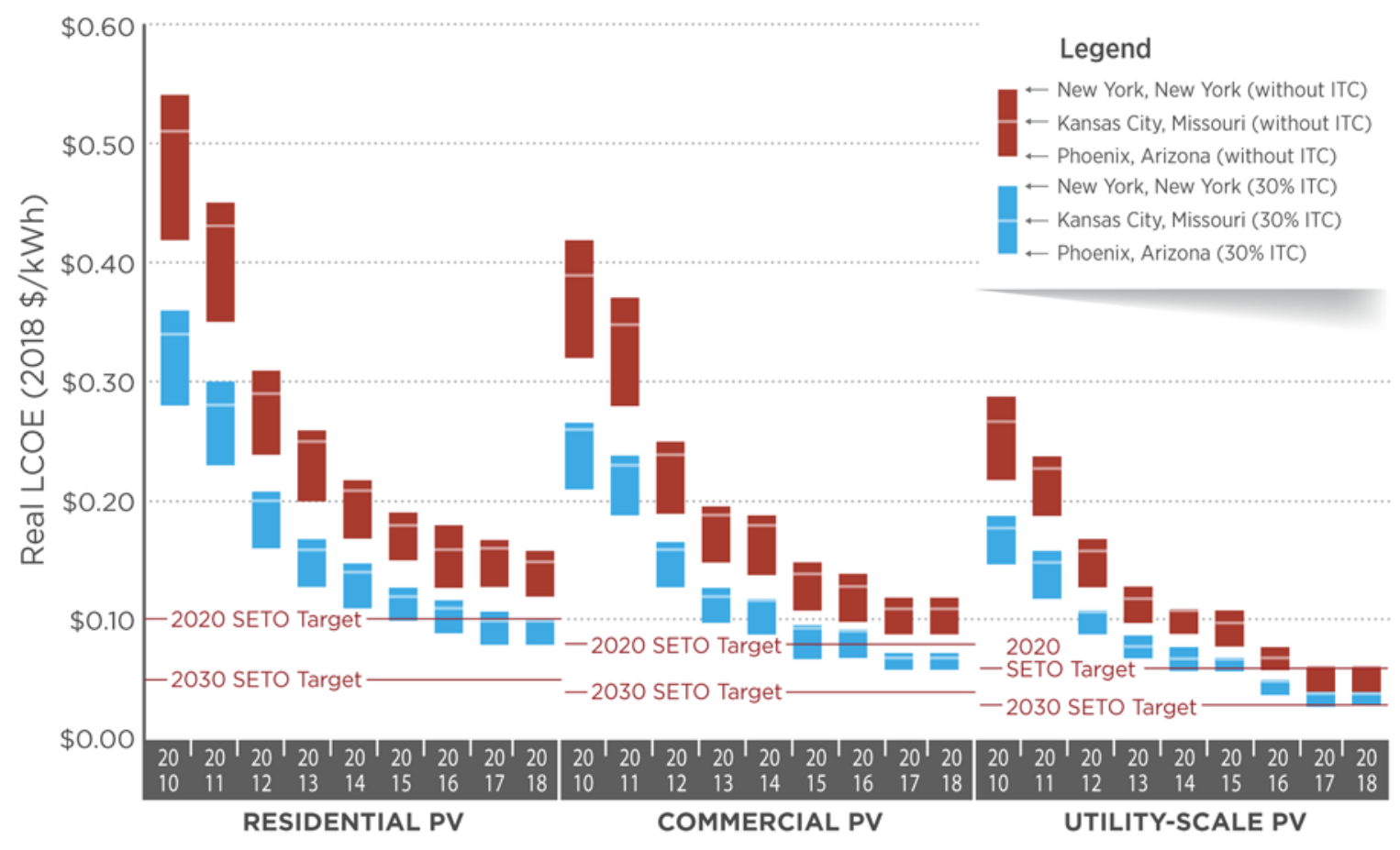

Figure ES-3. NREL PV LCOE benchmark summary (inflation adjusted), 2010-2018 


\section{Table of Contents}

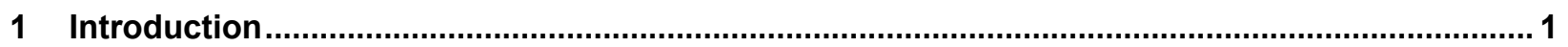

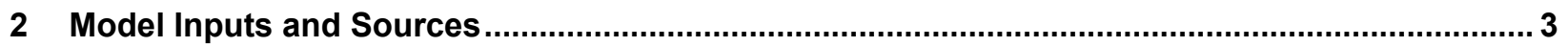

2.1 California's NEM Interconnection Applications Data Set ................................................ 3

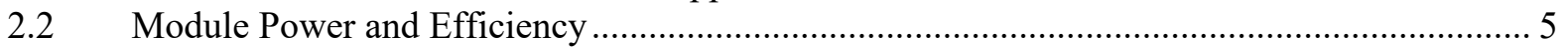

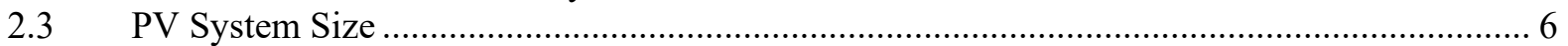

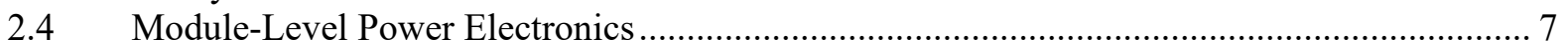

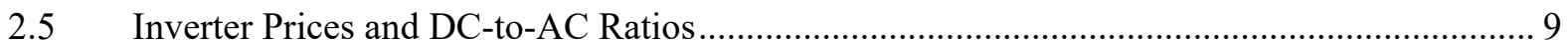

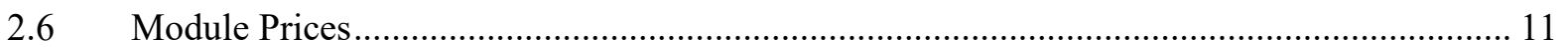

2.7 Small Installers vs. National Integrators in the Residential PV Model .................................. 13

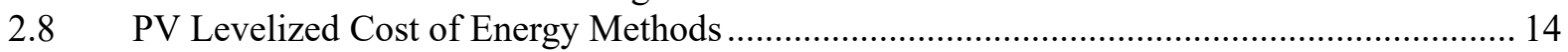

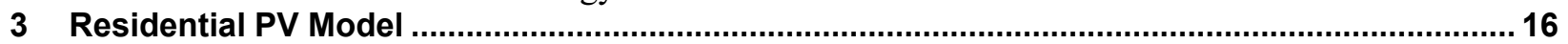

3.1 Residential Model Structure, Inputs, and Assumptions .................................................. 16

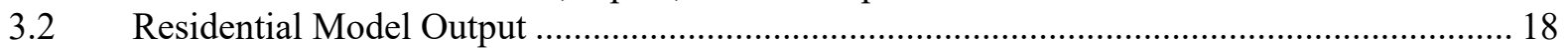

3.3 Residential Model Output vs. Reported Costs ................................................................. 19

3.4 Residential PV Price Benchmark Historical Trends........................................................... 20

3.5 Residential PV Levelized Cost of Energy Historical Trends .............................................. 21

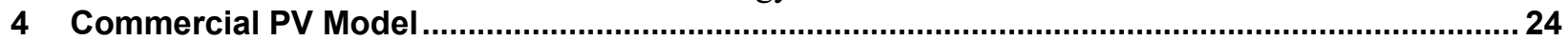

4.1 Commercial Model Structure, Inputs, and Assumptions.................................................... 24

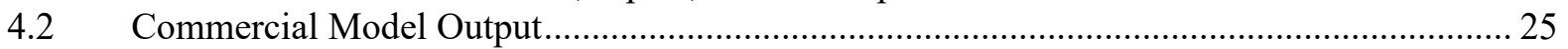

4.3 Commercial PV Price Benchmark Historical Trends............................................................... 27

4.4 Commercial PV Levelized Cost of Energy Historical Trends .............................................. 28

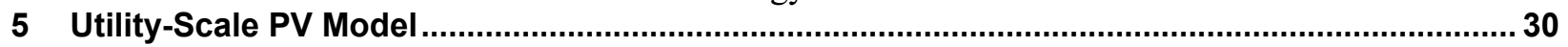

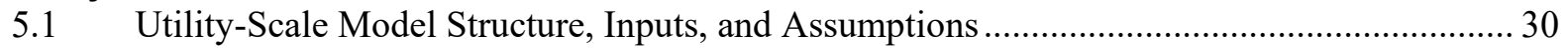

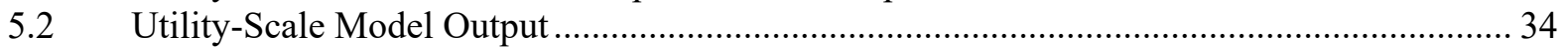

5.3 Utility-Scale PV Price Benchmark Historical Trends ............................................................. 36

5.4 Utility-Scale PV Levelized Cost of Energy Historical Trends ............................................ 37

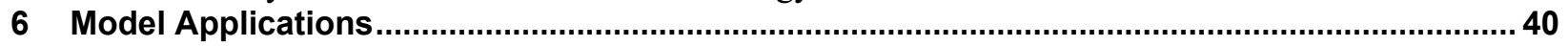

6.1 System Cost Reduction from Economies of Scale …............................................................ 40

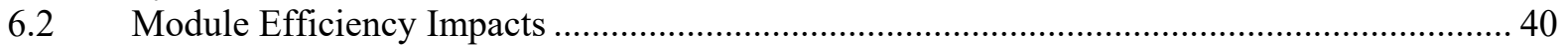

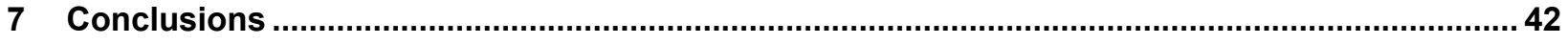

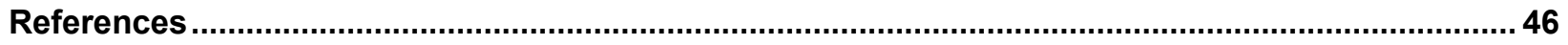

Appendix. PV System LCOE Benchmarks in 2018 USD ............................................................... 48 


\section{List of Figures}

Figure ES-1. NREL PV system cost benchmark summary (inflation adjusted), 2010-2018 ...................viii

Figure ES-2. Modeled trend of soft cost as a proportion of total cost by sector, 2010-2018 ....................

Figure ES-3. NREL PV LCOE benchmark summary (inflation adjusted), 2010-2018 …....................... xi

Figure 1. Growth of U.S. PV capacity, 2004-2017 (Bloomberg 2018) ................................................. 1

Figure 2. Installed capacities of residential and commercial PV systems covered by the California NEM

database (Go Solar CA 2018) compared with GTM data (GTM Research 2018), 2010-2017 .......... 4

Figure 3. Module power and efficiency trends from the California NEM database (Go Solar CA 2018), 2010-2017....

Figure 4. PV system size trends from the California NEM database (Go Solar CA 2018), 2010-2017 ...... 6

Figure 5. Residential inverter market in California from the California NEM database (Go Solar CA

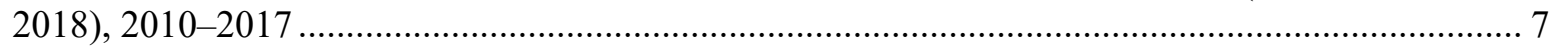

Figure 6. Commercial inverter market in California from the California NEM database (Go Solar CA

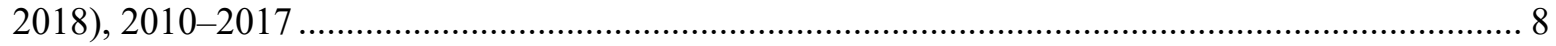

Figure 7. Non-MLPE inverter prices (USD/Wac) from PVinsights (2018), Q1 2018 ............................. 9

Figure 8. MLPE inverter shipments and prices (USD/Wac) from public corporate filings (Enphase 2018,

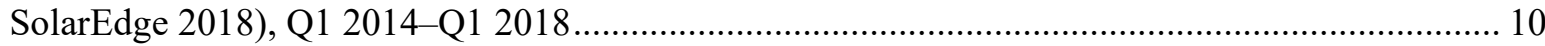

Figure 9. Ex-factory gate prices (spot prices) for U.S. and global multicrystalline-silicon modules from

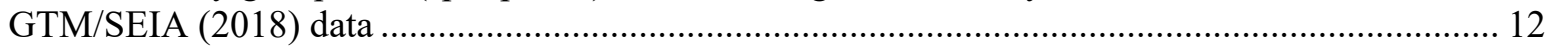

Figure 10. Total residential PV module market costs (2018 USD) ................................................... 12

Figure 11. Residential PV market share: integrator vs. installer, Q1 2014-Q1 2018 ............................. 13

Figure 12. Q1 2018 residential, commercial, and utility-scale O\&M costs by category .......................... 15

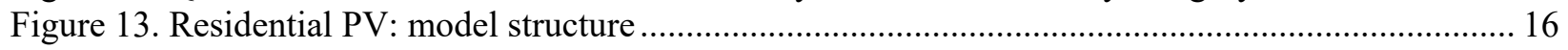

Figure 14. Q1 2018 U.S. benchmark: 6.2-kW residential system cost (2018 USD/Wdc)....................... 18

Figure 15. Q1 2018 benchmark by location: 6.2-kW residential system cost (2018 USD/Wdc) .............. 19

Figure 16. Q1 2018 NREL modeled cost benchmark (2018 USD/Wdc) vs. Q1 2018 company-reported costs .

Figure 17. NREL residential PV system cost benchmark summary (inflation adjusted), 2010-2018....... 21

Figure 18. LCOE for residential PV systems, by region, with and without ITC, 2010-2018 ................. 23

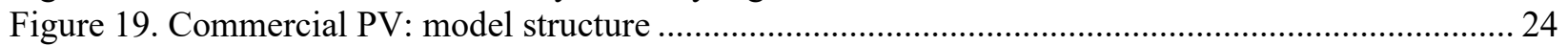

Figure 20. Q1 2018 U.S. benchmark: commercial PV system cost (2018 USD/Wdc)........................... 26

Figure 21. Q1 2018 benchmark by location: 200-kW commercial PV system cost (2018 USD/Wdc)..... 27

Figure 22. NREL commercial PV system cost benchmark summary (inflation adjusted), 2010-2018 ..... 27

Figure 23. LCOE for commercial PV systems, by region, with and without ITC, 2010-2018 ................ 29

Figure 24. Utility-scale PV: model structure ............................................................................. 30

Figure 25. Percentage of U.S. utility-scale PV systems using tracking systems, 2007-2017 (Bolinger and

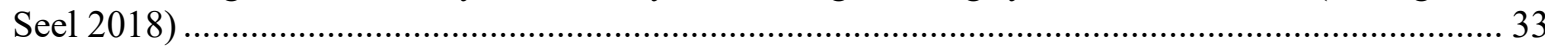

Figure 26. Utility-scale PV: 2017 capacity installed and percentage of unionized labor by state (BLS

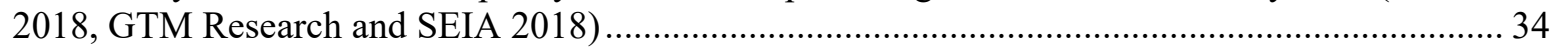

Figure 27. Q1 2018 benchmark by location: 100-MW utility-scale PV systems, EPC only

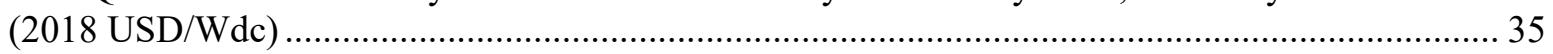

Figure 28. Q1 2018 U.S. benchmark: utility-scale PV total cost (EPC + developer), 2018 USD/Wdc ..... 36

Figure 29. NREL utility-scale PV system cost benchmark summary (inflation adjusted), 2010-2018 ..... 37

Figure 30. LCOE for utility-scale PV systems, by region, with and without ITC, 2010-2018 ................ 39

Figure 31. Model application: U.S. utility-scale one-axis tracking PV system cost reduction

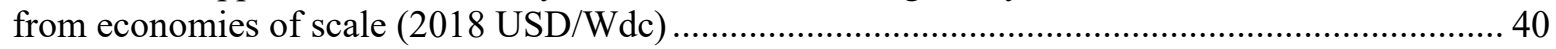

Figure 32. Modeled impacts of module efficiency on total system costs, 2018 .................................. 41

Figure 33. NREL PV system cost benchmark summary (inflation adjusted), 2010-2018 ...................... 43

Figure 34. Modeled trend of soft cost as a proportion of total cost by sector, 2010-2018 ..................... 45

Figure 35. NREL PV LCOE benchmark summary (inflation adjusted), 2010-2018 ............................. 45 


\section{List of Tables}

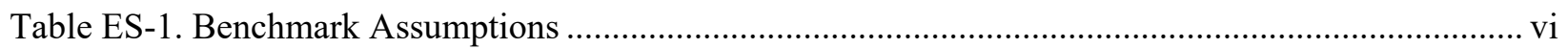

Table ES-2. Comparison of Q1 2017 and Q1 2018 PV System Cost Benchmarks .................................. ix

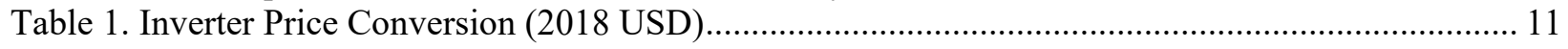

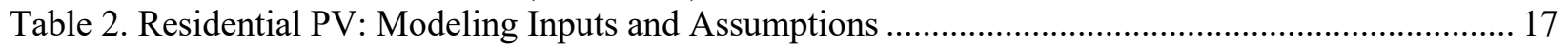

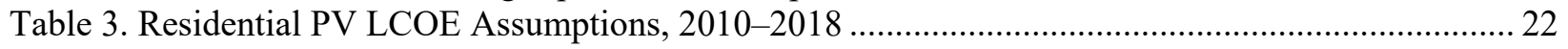

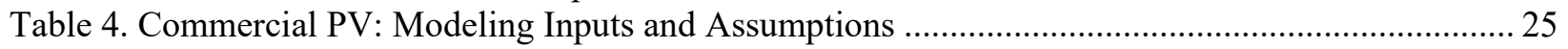

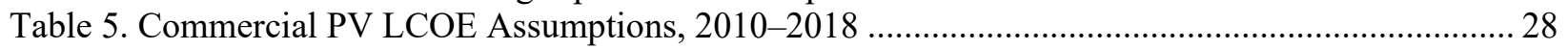

Table 6. Utility-Scale PV: Modeling Inputs and Assumptions ............................................................. 31

Table 7. Characteristics of Assuming 1,500 Vdc vs. 1,000 Vdc for Utility-Scale PV Systems ................ 32

Table 8. One-Axis Tracker and Fixed-Tilt Utility-Scale PV LCOE Assumptions, 2010-2018 ............... 38

Table 9. Comparison of Q1 2017 and Q1 2018 PV System Cost Benchmarks ....................................... 44

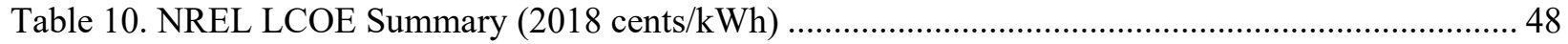




\section{Introduction}

Solar photovoltaic (PV) deployment has grown rapidly in the United States over the past several years. As Figure 1 shows, in 2017 new U.S. PV installations included $2.1 \mathrm{GW}$ in the residential sector, $1.5 \mathrm{GW}$ in the commercial sector, and $7.1 \mathrm{GW}$ in the utility-scale sector-totaling 10.7 GW across all sectors (Bloomberg 2018). Although this represents $30 \%$ less capacity than in 2016, it still represents 40\% growth over 2015 installations and the second highest installation year to date.

\section{Gigawatt DC}

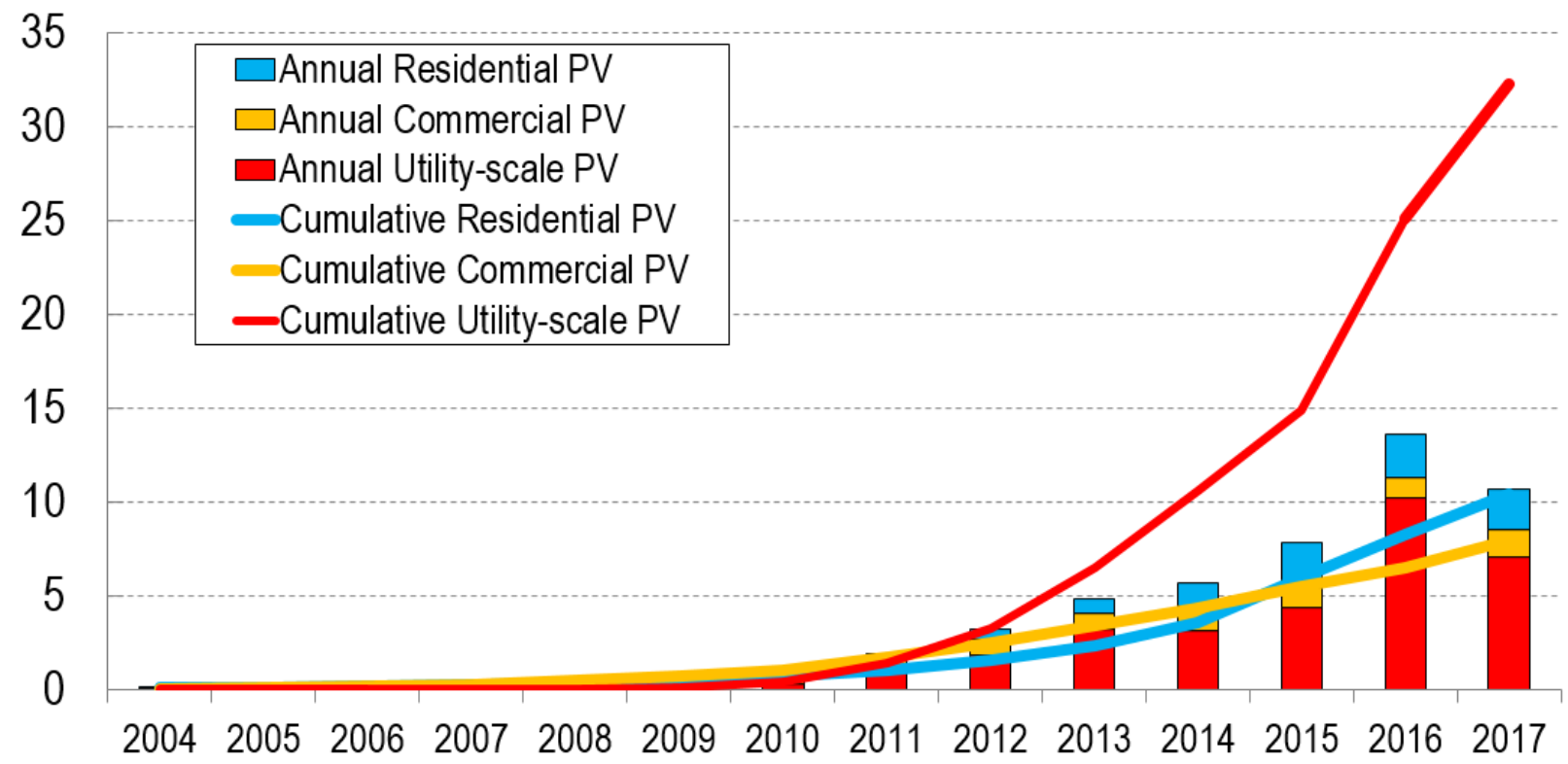

Figure 1. Growth of U.S. PV capacity, 2004-2017 (Bloomberg 2018)

This report continues tracking cost reductions by benchmarking costs of U.S. residential, commercial, and utility-scale PV systems built in Q1 2018. It was produced in conjunction with several related research activities at NREL and Lawrence Berkeley National Laboratory (LBNL), which are documented in Barbose and Darghouth (2017), Bolinger and Seel (2017) ${ }^{6}$, Chung et al. (2015), Feldman et al. (2015), and Fu et al. (2016).

Our benchmarking method includes bottom-up accounting for all system and projectdevelopment costs incurred when installing residential, commercial, and utility-scale systems, and it models the Q1 2018 costs for such systems excluding any previous supply agreements or contracts. In general, we attempt to model the typical installation techniques and business operations from an installed-cost perspective, and our benchmarks are national averages of installed capacities, weighted by state. The residential benchmark is further averaged across installer and integrator business models, weighted by market share. All benchmarks assume nonunion construction labor, although union labor cases are estimated for utility-scale systems.

\footnotetext{
${ }^{6}$ LBNL compares the bottom-up cost results among various entities, including our results.
} 
Our modeled costs can be interpreted as the sales price an engineering, procurement, and construction (EPC) contractor/developer might charge for a system before any developer fee or price gross-up (although our costs do include development costs). We use this approach owing to the wide variation in developer profits in all three sectors, where project pricing is highly dependent on region and project specifics such as local retail electricity rate structures, local rebate and incentive structures, competitive environment, and overall project or deal structures.

The remainder of this report is organized as follows. Section 2 describes our model inputs and sources. Sections 3, 4, and 5 show specific model inputs and outputs for the residential, commercial, and utility-scale PV sectors, including historical trends in system costs and the levelized costs of energy (LCOEs). Section 6 includes two additional applications of our cost modeling: system cost reduction from economies of scale and module efficiency impacts. Finally, Section 7 puts the results in context and offers conclusions. 


\section{Model Inputs and Sources}

This section describes our model inputs and sources. Section 2.1 describes our main data source, California's Net Energy Metering (NEM) Interconnection Applications Data Set. Sections 2.2 through 2.6 detail the inputs for the various components affecting PV system cost. Section 2.7 describes how we allocate installations to installers versus integrators in the residential PV model, and Section 2.8 describes our LCOE calculation methods.

\subsection{California's NEM Interconnection Applications Data Set}

We use the California NEM Interconnection Applications Data Set (CSI 2018) to benchmark generic system characteristics, such as system size, module power and efficiency, and choice of power electronics. This database is updated monthly and contains all interconnection applications in the service territories of the state's three investor-owned utilities (Pacific Gas \& Electric, Southern California Edison, and San Diego Gas \& Electric). Although there are other databases for other markets, such as Massachusetts and New York, we use only the California NEM database to inform these general benchmark characteristics because of its higher granularity and greater consistency. However, we do not use the California NEM database for regional cost analyses. Inputs and sources for regional analyses are described in subsequent sections of this report.

As shown in Figure 2, the California NEM database captures most residential capacity in California ( $81 \%$ of installed capacity in 2016 and $83 \%$ in 2017) and a sizable portion of commercial capacity (75\% of installed capacity in 2016 and 54\% in 2017). Note that:

- We analyze only rooftop systems in the database for the residential and commercial sectors. We exclude ground-mounted systems.

- We exclude systems with only alternating-current (AC) power records.

- We exclude systems that were still in the validation phase.

- We use GTM (2018) data to represent total installed capacities. 


\section{Annual Installation in California (MW DC)}

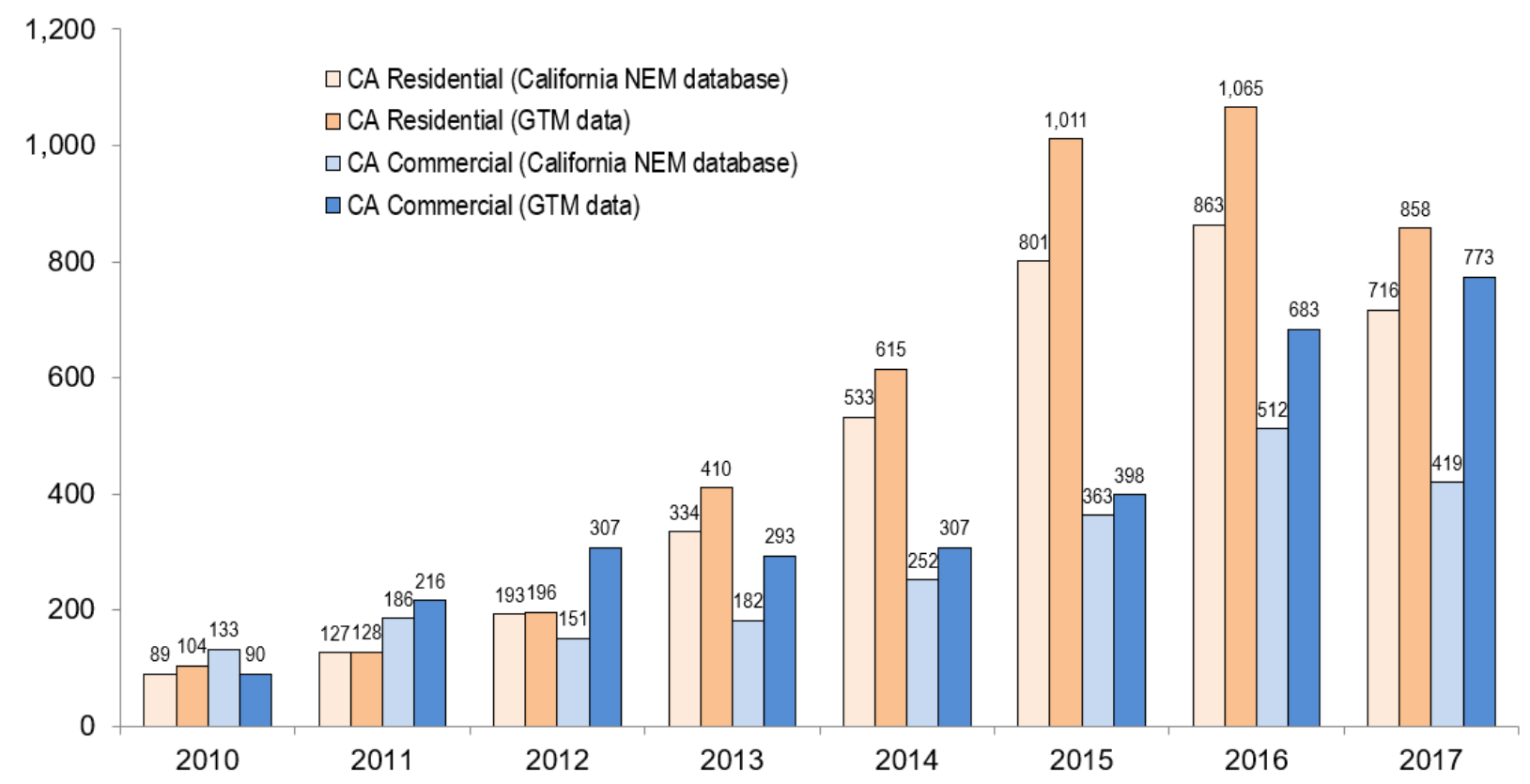

Figure 2. Installed capacities of residential and commercial PV systems covered by the California NEM database (Go Solar CA 2018) compared with GTM data (GTM Research 2018), 2010-2017 


\subsection{Module Power and Efficiency}

Figure 3 displays module power and efficiency data from the California NEM database. Since 2010, module power and efficiency in both sectors have steadily improved. We use the values of $17.2 \%$ (residential) and 19.1\% (commercial and utility-scale) module efficiency in our models. Because module selection may vary in different regions, the average module efficiencies in regions other than California may be different.

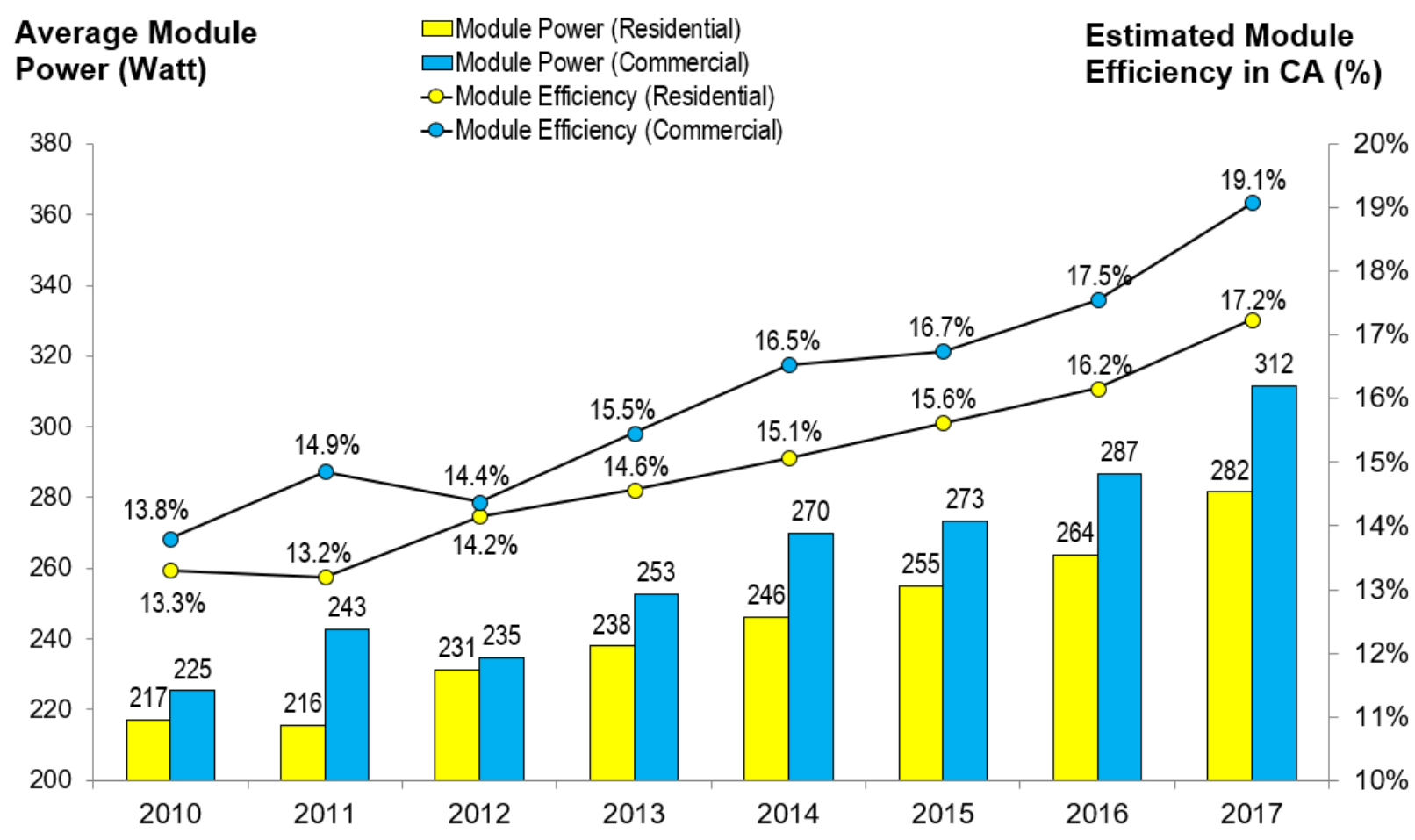

Figure 3. Module power and efficiency trends from the California NEM database (Go Solar CA 2018), 2010-2017 


\subsection{PV System Size}

Figure 4 displays average system sizes from the California NEM database. Average residential system sizes have not changed significantly over the past 6 years. We use the 2017 value of 6.2 $\mathrm{kW}$ as the baseline case in our residential cost model. Conversely, commercial system sizes have changed more frequently, likely reflecting the wide scope for "commercial customers," which include schools, office buildings, malls, retail stores, and government projects. We use $200 \mathrm{~kW}$ as the baseline case in our commercial model.

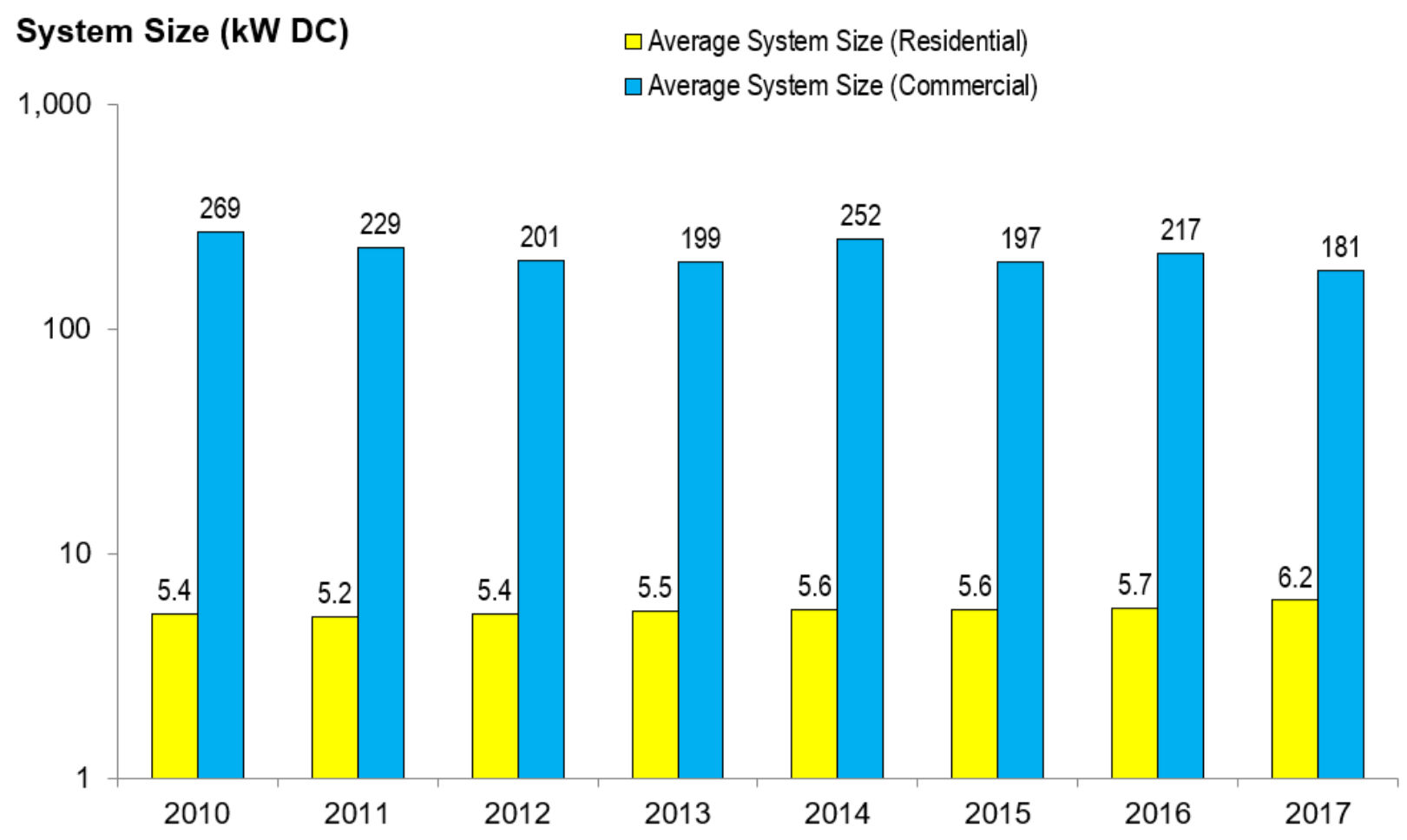

Figure 4. PV system size trends from the California NEM database (Go Solar CA 2018), 2010-2017 


\subsection{Module-Level Power Electronics}

Microinverters and DC power optimizers are collectively referred to as module-level power electronics (MLPE). By allowing designs with different roof configurations (orientations and tilts) and constantly tracking the maximum power point for each module, MLPE provide an optimized design solution at the module level.

\section{Annual Installation (MW DC)}

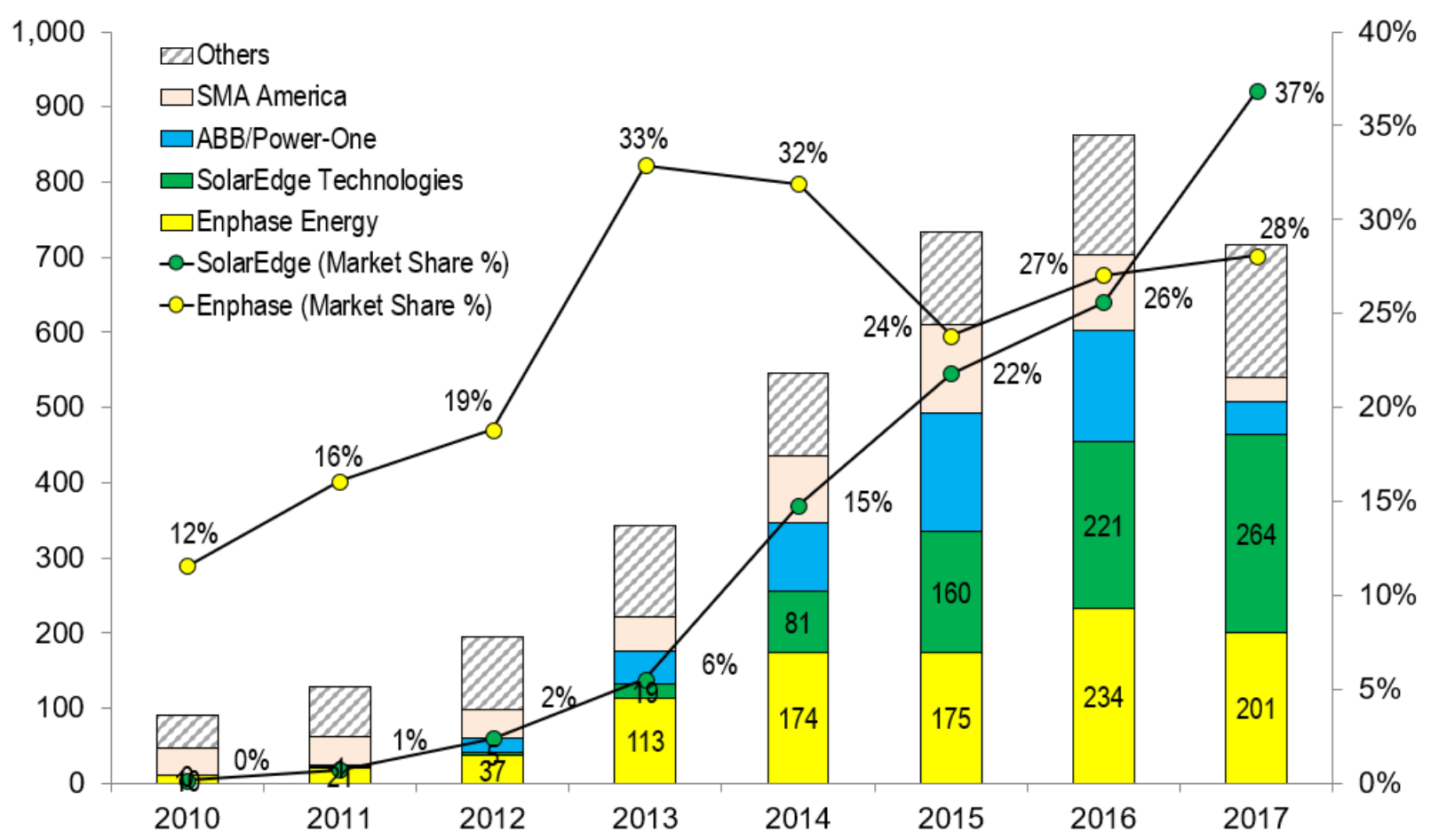

Figure 5. Residential inverter market in California from the California NEM database (Go Solar CA 2018), 2010-2017

7 "Others" represents other companies with small market shares. Although some companies may also have MLPEbased inverter products, we assume that SolarEdge and Enphase represent MLPE inverter manufacturers. 
In 2017, MLPE — represented by the combined share of Enphase microinverters and SolarEdge DC power optimizer inverter solutions - reached $65 \%$ of the total California residential market share (Figure 5). In our residential system cost model, string inverter, power optimizer, and microinverter options are modeled separately, and their market shares (35\%, 37\%, and 28\%) are used for the weighted-average case. Conversely, MLPE growth (represented by Enphase and SolarEdge) has been slow in California's commercial sector, reaching a share of only $8 \%$ in 2017 (Figure 6). Thus, we do not include MLPE inverter solutions in our commercial model.

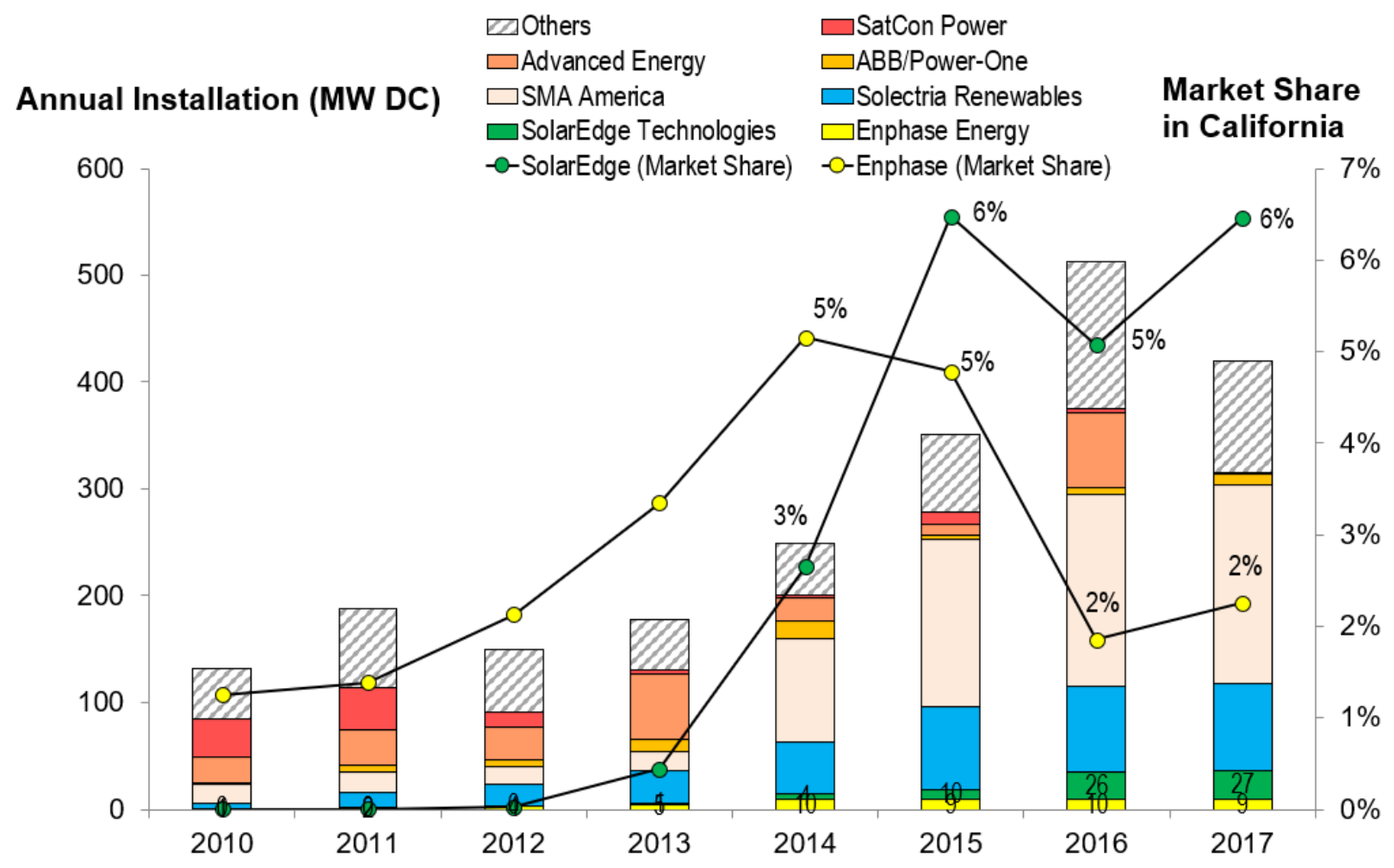

Figure 6. Commercial inverter market in California from the California NEM database (Go Solar CA 2018), 2010-2017 


\subsection{Inverter Prices and DC-to-AC Ratios}

As shown in Figure 7, we source non-MLPE inverter prices from the PVinsights (2018) database, which contains typical global prices between Tier 1 suppliers and developers in the market. For MLPE inverter prices, we use data from public corporate filings, shown in Figure 8 (Enphase 2018, SolarEdge 2018). ${ }^{8}$ Enphase's Q1 2018 revenue per inverter capacity shipped was $\$ 0.45 / \mathrm{Wac}$, which represents the typical microinverter price. SolarEdge's Q1 2018 revenue per inverter capacity shipped was $\$ 0.26 / \mathrm{Wac}$, including sales from DC power optimizers, string inverters, and monitoring equipment, which are typically included in one product offering. GTM Research estimates a DC power optimizer cost of \$0.06/Wac (GTM Research 2018), implying a string inverter and monitoring equipment price of $\$ 0.20 / \mathrm{Wac}^{9}$

We convert the USD/Wac inverter prices from Figure 7 and Figure 8 to USD/Wdc using the DCto-AC ratios shown in Table 1. In our benchmark, we use USD/Wdc for all costs, including inverter prices.

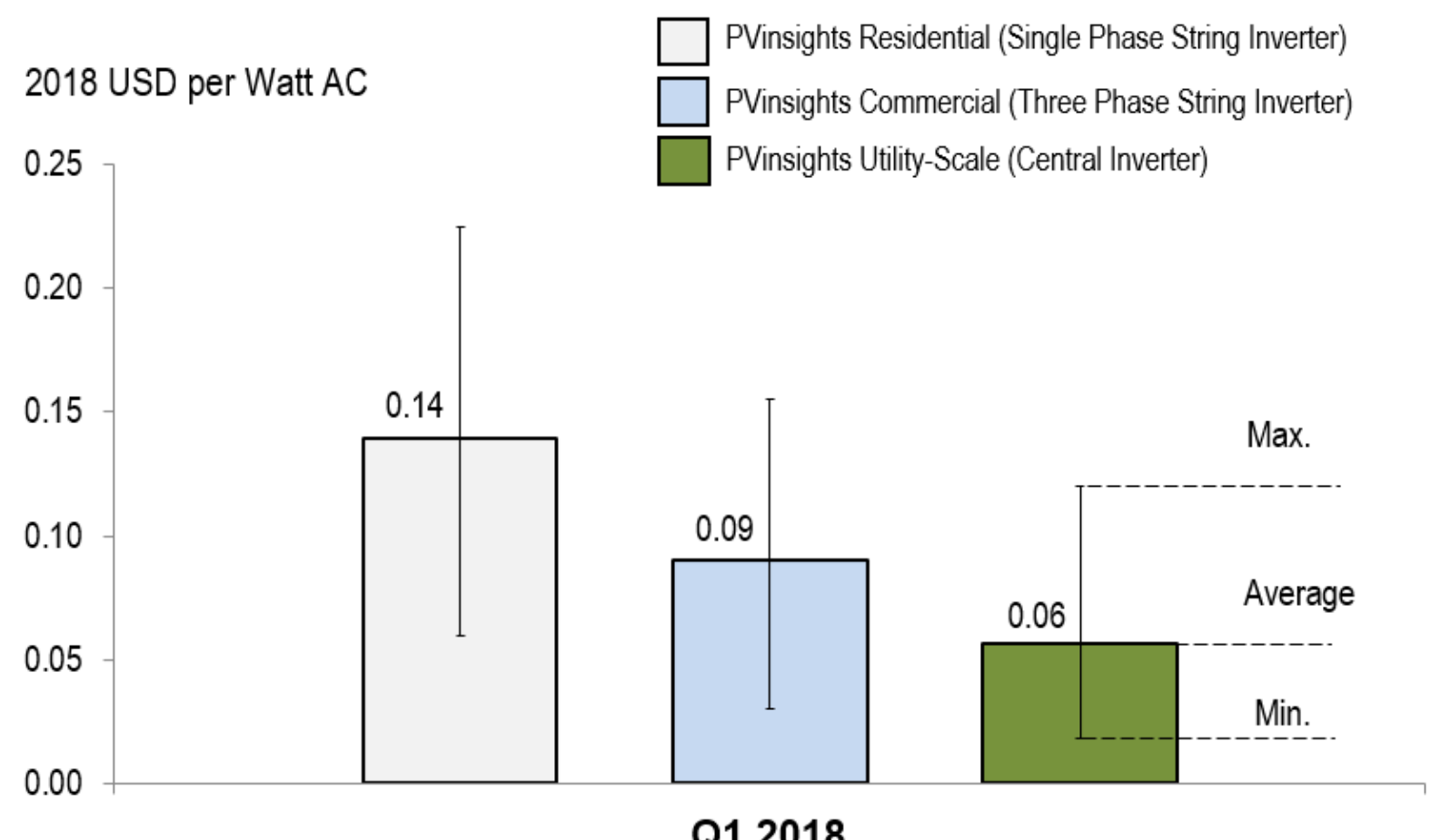

Figure 7. Non-MLPE inverter prices (USD/Wac) from PVinsights (2018), Q1 2018

\footnotetext{
${ }^{8}$ All sourced inverter prices are quoted in USD/Wac unless otherwise noted.

${ }^{9}$ DC Power Optimizer String Inverter and monitoring equipment Q1 2018 price of $\$ 0.20 / \mathrm{Wac}$ is calculated by subtracting the price of a DC power optimizer, as reported by GTM Research of $\$ 0.06 / \mathrm{Wac}$, by the implied price of SolarEdge's MLPE package of DC power optimizers, string inverters, and monitoring equipment (i.e. \$0.26/Wac $\$ 0.06 / \mathrm{Wac}=\$ 0.20 / \mathrm{Wac})$.
} 


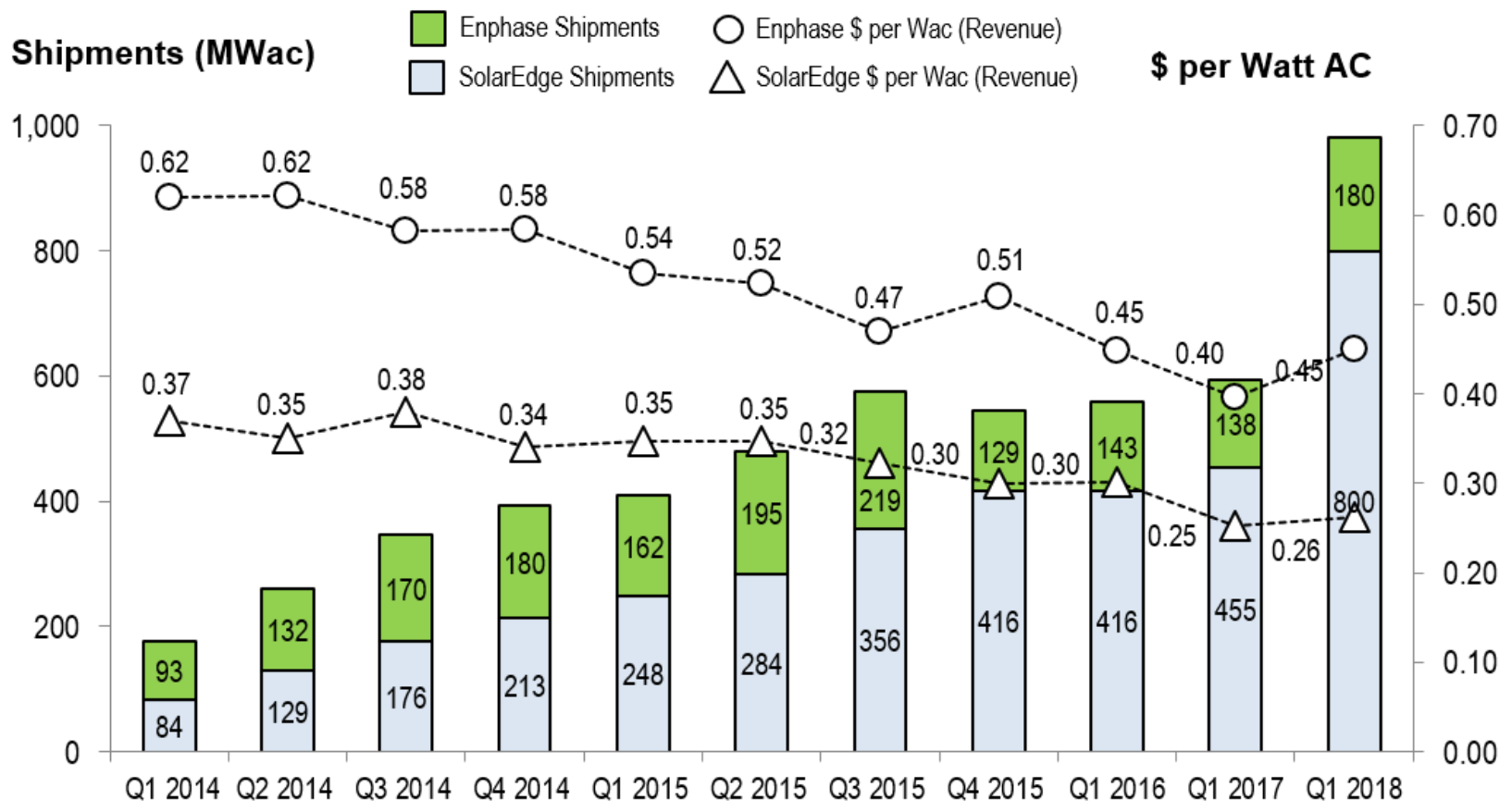

Figure 8. MLPE inverter shipments and prices (USD/Wac) from public corporate filings (Enphase 2018, SolarEdge 2018), Q1 2014-Q1 2018 
Table 1. Inverter Price Conversion (2018 USD)

\begin{tabular}{lllll}
\hline Inverter Type & Sector & USD/Wac & DC-to-AC Ratio $^{\mathrm{a}}$ & USD/Wdc \\
\hline $\begin{array}{l}\text { Single-Phase String } \\
\text { Inverter }\end{array}$ & $\begin{array}{l}\text { Residential PV (non- } \\
\text { MLPE) }\end{array}$ & 0.14 & 1.15 & 0.12 \\
\hline $\begin{array}{l}\text { Microinverter } \\
\text { RC Power Optimizer }\end{array}$ & Residential PV (MLPE) & 0.20 & 1.15 & 0.39 \\
$\begin{array}{l}\text { String Inverter } \\
\begin{array}{l}\text { Three-Phase String } \\
\text { Inverter }\end{array}\end{array}$ & $\begin{array}{l}\text { Commercial PV (non- } \\
\text { MLPE) }\end{array}$ & 0.09 & 1.15 & 0.18 \\
\hline $\begin{array}{l}\text { Central Inverter } \\
\text { Utility-scale PV (fixed-tilt) }\end{array}$ & 0.06 & 1.36 (oversized) & 0.04 \\
\hline Central Inverter & $\begin{array}{l}\text { Utility-scale PV (1-axis } \\
\text { tracker) }\end{array}$ & 0.06 & 1.30 (oversized) $^{\mathrm{b}}$ & 0.05 \\
\hline
\end{tabular}

All inverter prices include the cost of monitoring equipment.

a We updated the central inverter DC-to-AC ratios using Lawrence Berkeley National Laboratory data (Bolinger and Seel 2018); for the other ratios, we use the estimates from our 2017 report (Fu et al. 2017) based on interview feedback (NREL 2018).

${ }^{b} A D C$-to-AC ratio larger than one means that the PV array's DC rating is higher than the inverter's AC rating. This increases inverter utilization, although it also results in some PV energy curtailment, or "clipping," during the sunniest periods when PV output exceeds the inverter's capacity. PV module prices have dropped more rapidly than inverter prices have, and many utility-scale PV developers have found it economical to oversize their PV arrays. The resulting AC-generation gains during periods of less-thanpeak PV production more than offset the losses from occasional peak-period clipping (Bolinger and Seel 2016).

\subsection{Module Prices}

We assume an ex-factory gate (spot or first-buyer) price of $\$ 0.47 / \mathrm{Wdc}$ for Tier 1 crystallinesilicon PV modules in Q1 2018. As Figure 9 shows, U.S. spot prices declined substantially between 2014 and 2016, approaching global spot prices. In 2017, however, U.S. spot prices rose as global spot prices continued to decline. Several factors, including uncertainty about U.S. policy on imported modules, may have contributed to the divergence between U.S. and global spot prices. In early 2018 , U.S. spot prices were at $\$ 0.47 / \mathrm{Wdc}-\$ 0.17 / \mathrm{Wdc}$ above the global spot price - and appeared to be leveling off.

Although commercial and utility-scale PV developers typically can procure modules at or near the spot price, residential integrators and installers incur additional supply chain costs (Figure 10). Historical inventory price can create a price lag (approximately six months) for the market module price in the residential sector when the modules from previous procurement are installed in today's systems. In the Q1 2017 residential PV benchmark this supply chain cost represented $\$ 0.21 / \mathrm{W}$ - a $60 \%$ premium. Because US module ASP was lower than Q1 2018 pricing for much of 2017 we do not include this supply chain cost in the current benchmark. We assume that small installers and national integrators are both subject to a $15 \%(\$ 0.07 / \mathrm{W})$ premium on the spot price for module shipping and handling (NREL 2018), consistent with Q1 2017 residential PV 
benchmark. Small installers are subject to an additional 35\% (\$16/W) premium owing to smallscale procurement (Bloomberg 2018), increasing from an assumed 20\% premium in the Q1 2017 residential PV benchmark. Both types of companies are also subject to $6.9 \%$ sales tax (weighted national average), bringing the small installer module cost to $\$ 0.76 / \mathrm{W}$ and the national integrator cost to $\$ 0.58 / \mathrm{W}$ (Bloomberg 2018).

\section{\$ per Watt}

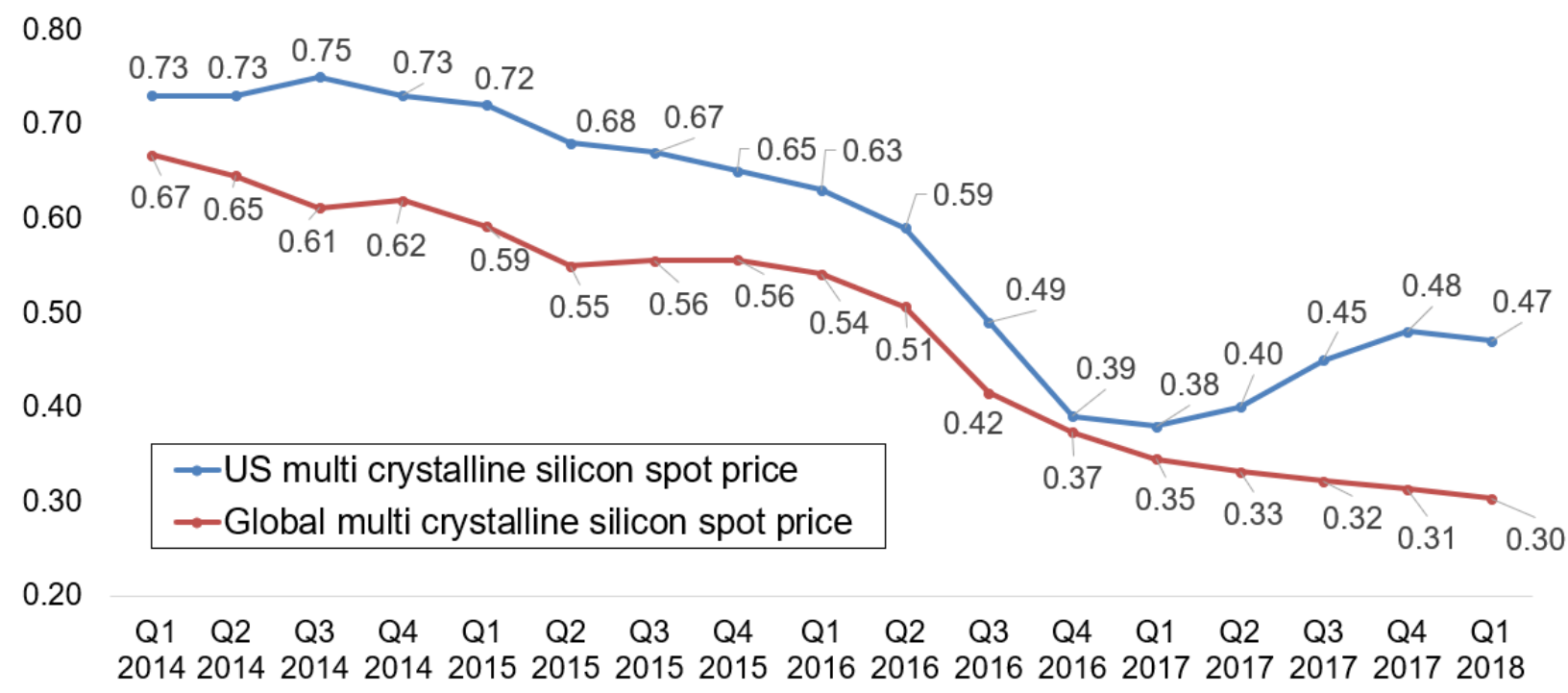

Figure 9. Ex-factory gate prices (spot prices) for U.S. and global multicrystalline-silicon modules from GTM/SEIA (2018) data

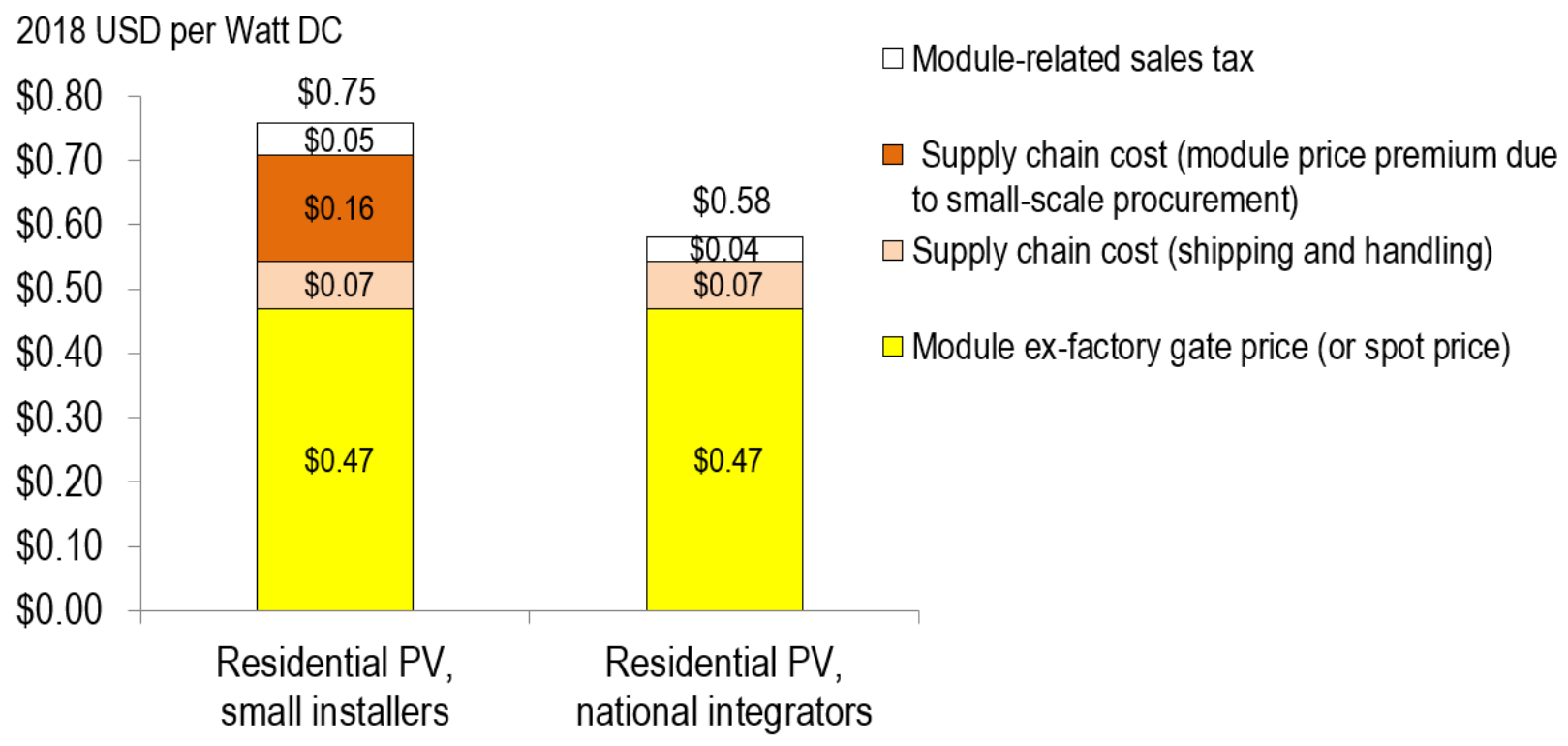

Figure 10. Total residential PV module market costs (2018 USD) 


\subsection{Small Installers vs. National Integrators in the Residential PV Model}

Our residential PV benchmark is based on two different business structures: "small installer" and "national integrator." We define small installers as businesses that engage in lead generation, sales, and installation, but do not provide financing solutions. National integrators perform all small installer functions, and they provide financing and system monitoring for third-partyowned systems. In our models, the difference between small installers and national integrators is anifested in the overhead and sales and marketing cost categories, where the national integrator is modeled with higher expenses for customer acquisition, financial structuring, and asset management.

To estimate the split in market share between small installers and national integrators, we use data compiled from corporate filings (Sunrun 2018, Vivint Solar 2018) and GTM Research and SEIA (2018). As shown in Figure 11, since 2015 small installers have gained more market share than national integrators, in part because the direct ownership business model, led by installers, has become more popular than third-party ownership. We use the 33\% integrator and $67 \%$ installer market shares in our Q1 2018 model to compute the national weighted-average case in our residential PV model.

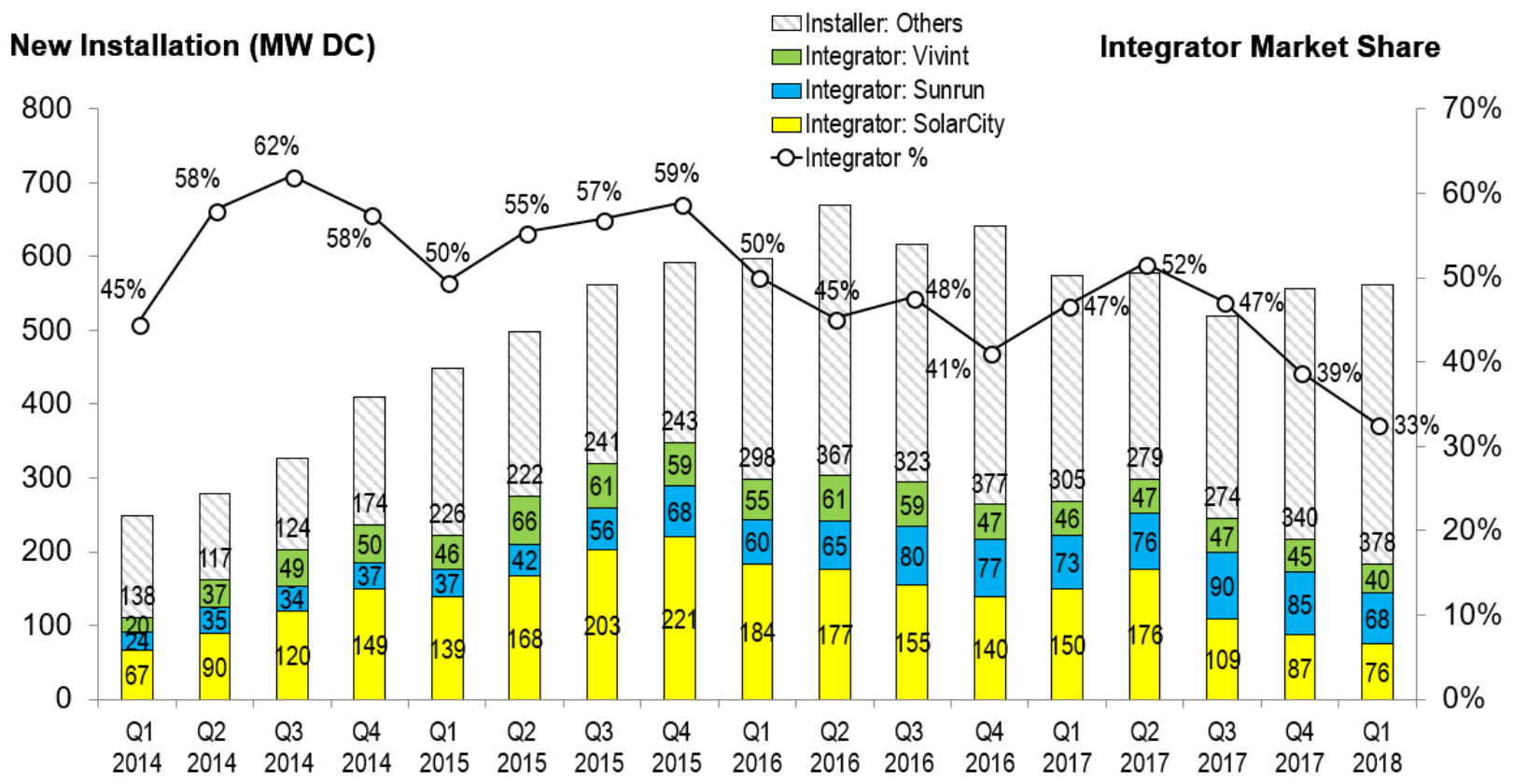

Figure 11. Residential PV market share: integrator vs. installer, Q1 2014-Q1 2018 GTM Research and SEIA 2018, Sunrun 2018, Vivint Solar 2018 


\subsection{PV Levelized Cost of Energy Methods}

Although LCOE is not a perfect metric to measure the competiveness of PV within the energy marketplace, it incorporates many PV metrics important to energy costs beyond upfront installation costs. In the previous edition of this report (Fu et al. 2017), we performed a literature review to determine inputs not already benchmarked in the report. When LCOE assumptions were not found in the selected literature in a given year, straight-line changes were assumed between any two values. This year, we inform the inputs using ongoing NREL benchmarking work. We input these assumptions into NREL's System Advisor Model (SAM), a performance and financial model, ${ }^{10}$ to calculate real LCOEs (considering inflation) for various locations.

\section{Annual Degradation}

In January 2018, NREL and DOE interviewed nine independent engineers and PV project financiers, who said they assume an annual PV module degradation of $0.7 \%$ per year. For certain projects with specific project and system characteristics that have been well vetted, some independent engineers assume a $0.5 \%$ annual degradation (Feldman et al. 2018). Because this lower value only applies to specific projects, we benchmark the higher degradation rate.

\section{Operations and Maintenance}

In 2018, a PV O\&M working group convened under the sponsorship of DOE's Solar Energy Technologies Office released a model (apsuite.sunspec.org) and method to calculate the cost associated with PV system O\&M. O\&M measures in the cost model correlate to the PV O\&M services described in NREL et al. (2016) ${ }^{11}$; O\&M cost drivers in the model ultimately will be informed by actuarial failure and repair data, but current default values reflect the best judgement of the working group.

O\&M costs in the NREL O\&M cost model include preventative maintenance, scheduled at regular intervals with costs increasing at an inflationary rate, as well as corrective maintenance to replace components. The model derives corrective maintenance by multiplying the replacement cost, including labor, by the probability that a failure will occur each year based on actuarial data. Component failure probabilities for each year are calculated using a Weibull, log-normal, or other distribution based on actual data, where possible.

As shown in Figure 12, O\&M costs include inverter replacement, which was a separately reported category from O\&M costs in previous reports. The current benchmarks without inverter replacement are $\$ 11.5 / \mathrm{kW} / \mathrm{yr}$ (residential), $\$ 12.0 / \mathrm{kW} / \mathrm{yr}$ (commercial), $\$ 9.1 / \mathrm{kW} / \mathrm{yr}$ (utility-scale, fixed-tilt), and $\$ 10.4 / \mathrm{kW} / \mathrm{yr}$ (utility-scale, tracking), significantly below previous O\&M-only benchmark estimates. This may indicate differences in assumptions about what type of work is included in O\&M practices, or it may indicate that previous benchmarks incorporated some inverter replacement costs in both categories.

\footnotetext{
${ }^{10}$ See https://sam.nrel.gov/.

${ }^{11}$ https://www.nrel.gov/docs/fy17osti/67553.pdf
} 


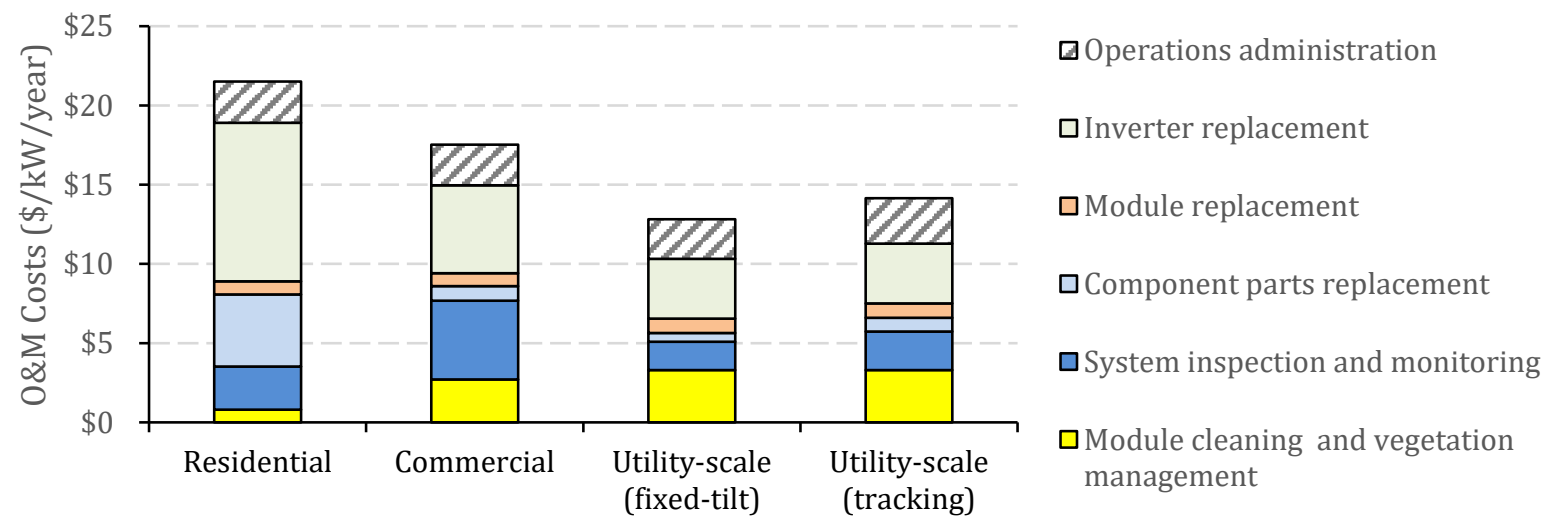

Figure 12. Q1 2018 residential, commercial, and utility-scale O\&M costs by category

\section{System losses}

Energy losses occur between PV generation and output to the grid owing to AC and DC wiring losses, soiling, inverter mismatch, and shading and snow for certain systems. We aggregate the losses into two categories: pre-inverter derate (or DC losses) and inverter efficiency (or AC losses).

Based on data analyzed by NREL, previous system loss benchmarks are consistent with current performance in the field, so these benchmarks have not been changed for 2018. We do assume a higher-voltage inverter in this year's utility-scale PV benchmark: 1,500 V rather than the 1,000 $\mathrm{V}$ used previously. However, increasing voltage typically has a negligible overall impact on losses. On the DC side, it reduces conductor losses per length of conductor, yet system layouts typically move to longer string lengths resulting in similar overall losses on the DC side (although cost is reduced). On the AC side, AC loss factors have little to do with the DC system voltage, so typically the AC losses will not change with higher DC voltages.

\section{Financing}

In 2018, NREL published its third DOE-sponsored effort to benchmark financing costs across the residential, commercial, and utility-scale PV markets, as part of its larger effort to benchmark the components of PV system costs (Feldman et al. 2016, Feldman and Schwabe 2017, Feldman and Schwabe 2018). All data compiled for these reports are derived from a combination of basic literature reviews, product research, and interviews with industry professionals.

From 2017 to 2018, there was a modest reduction in the cost of equity for PV projects, debt interest rates remained approximately the same, and the debt fraction increased (in part due to the lowering in 2017 of the federal corporate tax rate). That said, the values each year generally fall within the same range. Given the limited sample size of respondents each year, and the range of responses, we have kept our 2018 financing assumptions unchanged from 2017. 


\section{Residential PV Model}

This section describes our residential model's structure, inputs, and assumptions (Section 3.1), output (Section 3.2), differences between modeled output and reported costs (Section 3.3), and historical PV price (Section 3.4) and LCOE (Section 3.5) trends.

\subsection{Residential Model Structure, Inputs, and Assumptions}

We model a 6.2-kW residential rooftop system using 60-cell, multicrystalline, 17.2\%-efficient modules from a Tier 1 supplier and a standard flush mount, pitched-roof racking system. Figure 13 presents the cost drivers and assumptions, cost categories, inputs, and outputs of the model. Table 2 presents modeling inputs and assumptions in detail.

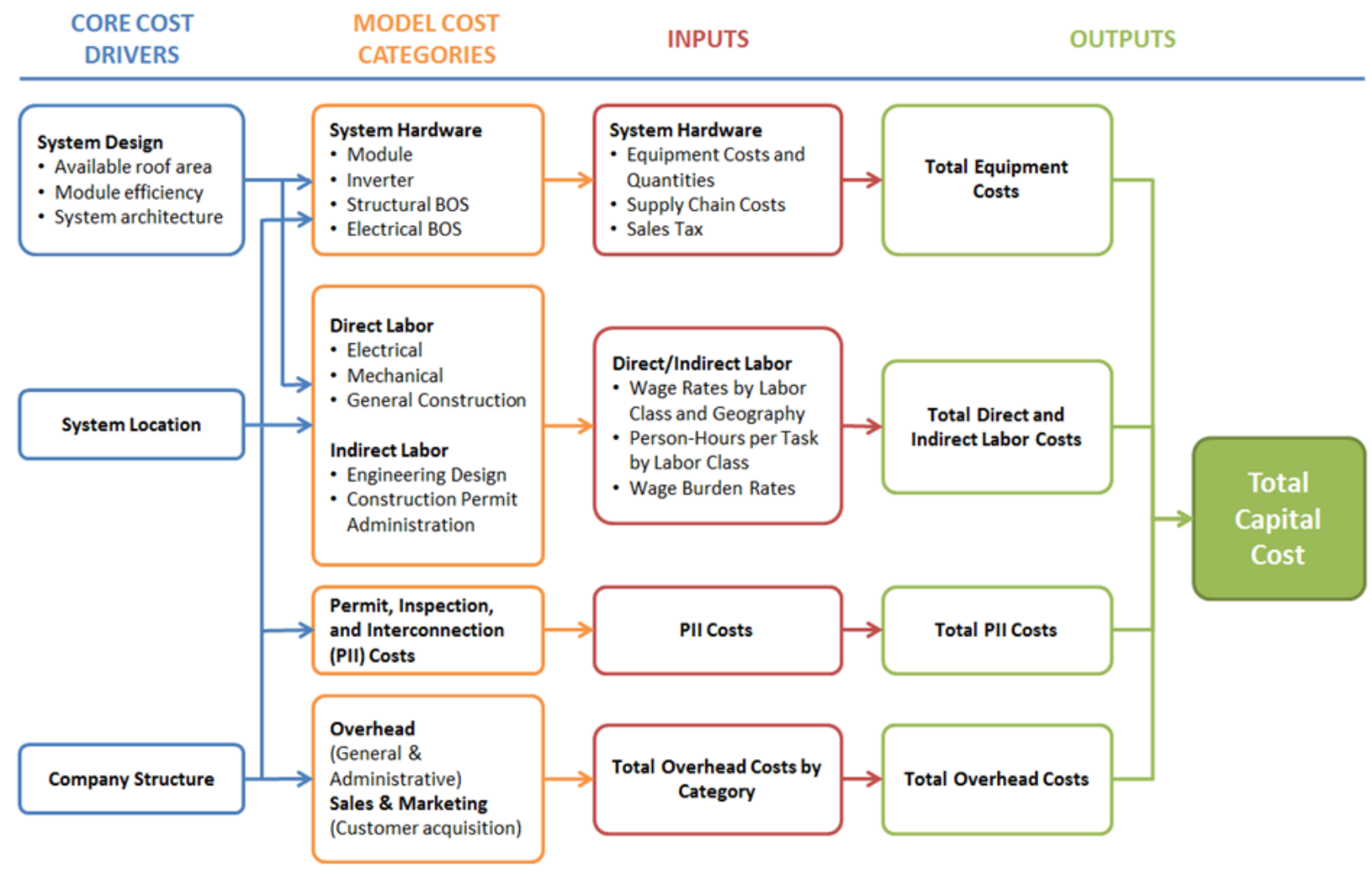

Figure 13. Residential PV: model structure 
Table 2. Residential PV: Modeling Inputs and Assumptions

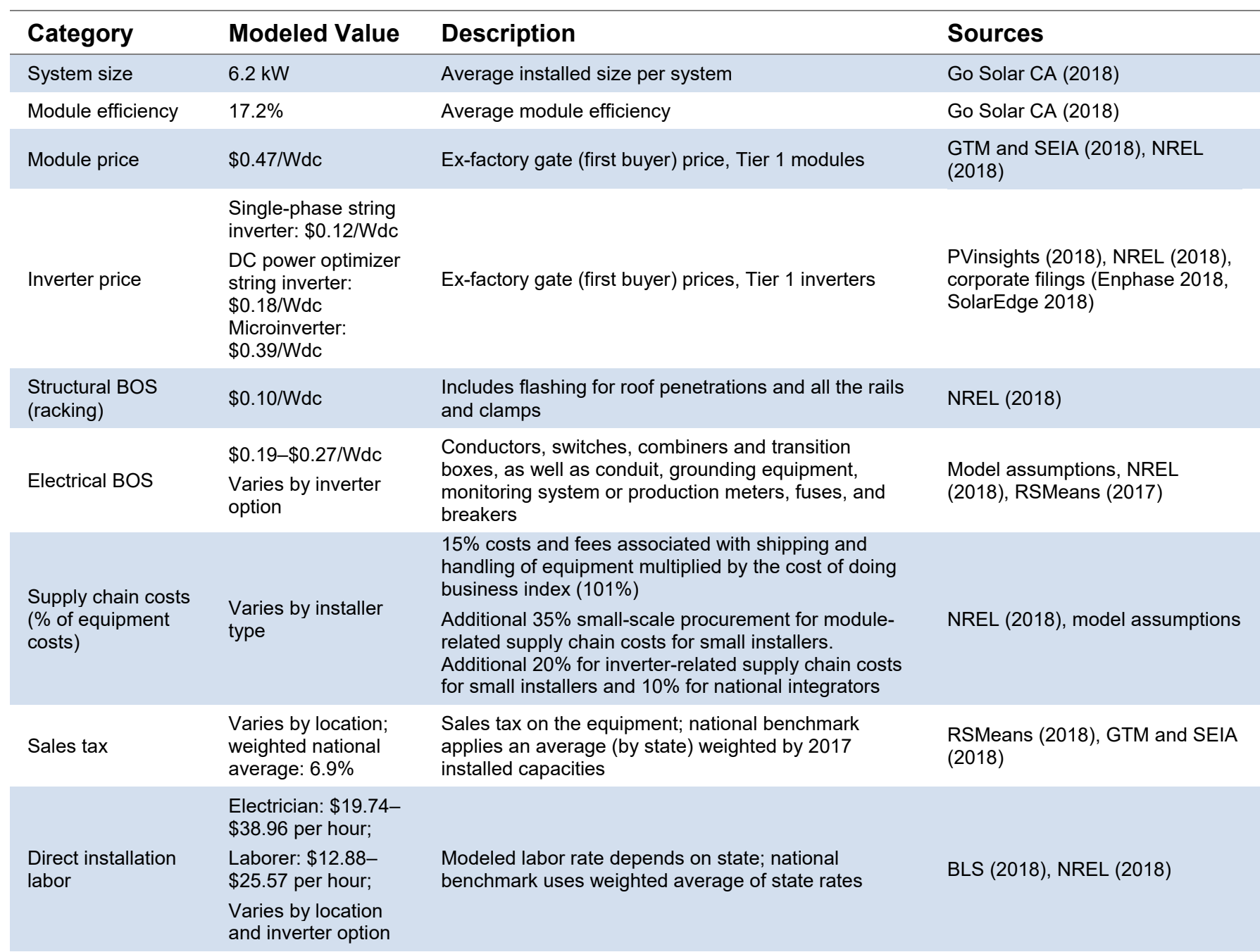

Burden rates (\% of Total nationwide Workensenstion (state-weighted average), Burden rates (\% of Total nationwide federal and state unemployment insurance, Federa direct labor) average: $31.8 \%$ Insurance Contributions Act (FICA), builders risk, public liability

Includes assumed building permitting fee of $\$ 200$ and six office staff hours for building permit preparation and submission, and interconnection application preparation and submission

Total cost of sales and marketing activities over the last year-including marketing and advertising, sales calls, site visits, bid preparation, and contract negotiation; adjusted based on state "cost of doing business" index

General and administrative expenses-including fixed overhead expenses covering payroll (excluding permitting payroll), facilities, administrative, finance, legal, information technology, and other corporate functions as well as office expenses; adjusted based on state "cost of doing business" index

Fixed percentage margin applied to all direct costs including hardware, installation labor, direct sales and marketing, design, installation, and permitting fees

Profit (\%) $\quad 17 \%$
RSMeans (2018)

NREL (2018)

NREL (2017), Sunrun (2017), Vivint Solar (2017), Feldman et al. (2013)
NREL (2018), Feldman et al. (2013) 


\subsection{Residential Model Output}

Figure 14 presents the U.S. national benchmark from our residential model. The national benchmark represents an average weighted by 2017 state installed capacities. Market shares of $67 \%$ for installers and $33 \%$ for integrators are used to compute the national weighted average. String inverter, power optimizer, and microinverter options are each modeled individually, and the "mixed" case applies their market shares $(35 \%, 37 \% \text {, and } 28 \%)^{12}$ as weightings.

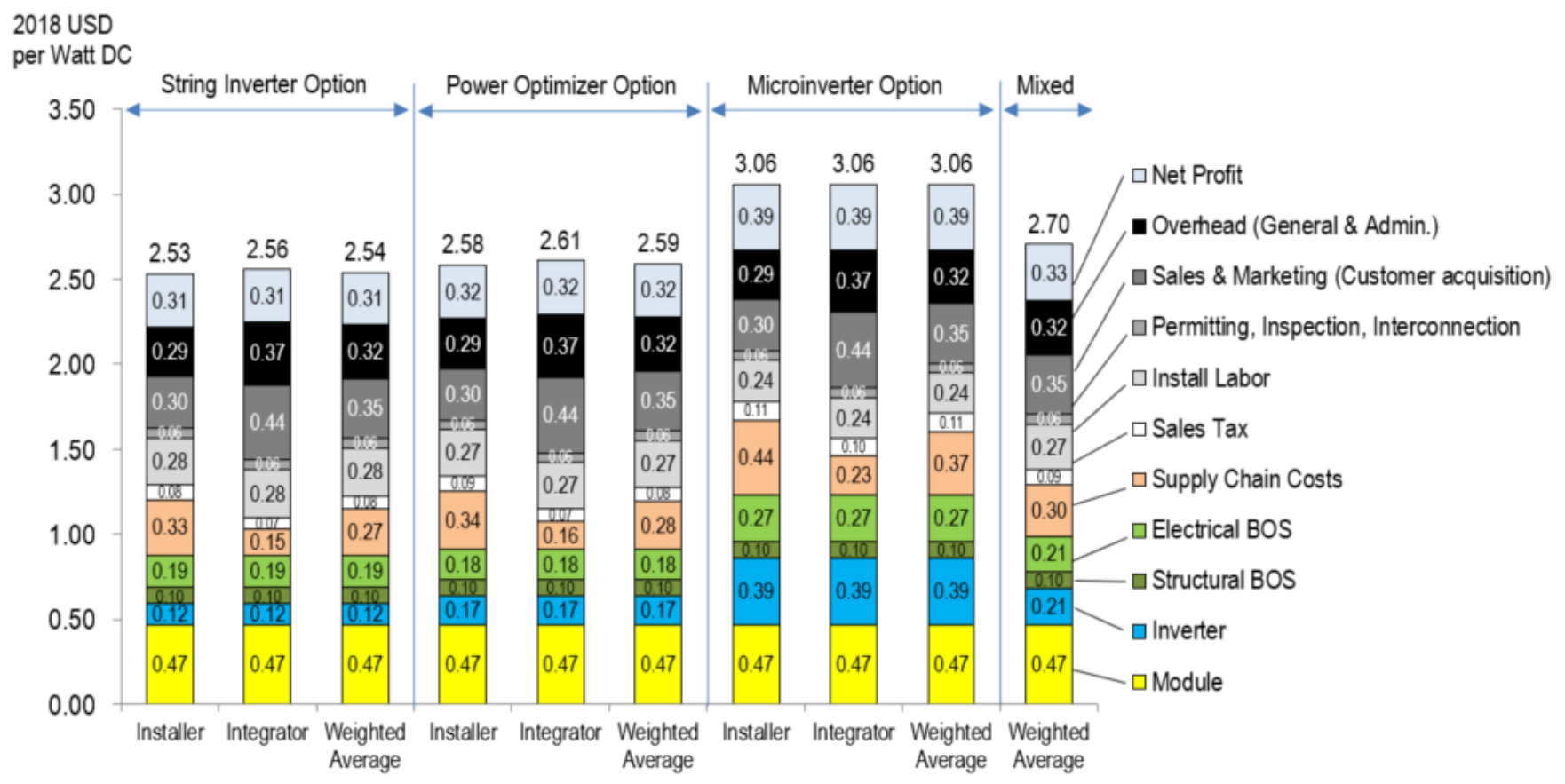

Figure 14. Q1 2018 U.S. benchmark: 6.2-kW residential system cost (2018 USD/Wdc)

Figure 15 presents the benchmark in the top U.S. PV markets (by 2018 installations), reflecting differences in supply chain and labor costs, sales tax, and SG\&A expenses - that is, the cost of doing business (Case 2012).

\footnotetext{
${ }^{12}$ This market share combination only reflects the California residential sector and may not reflect the actual national market shares.
} 


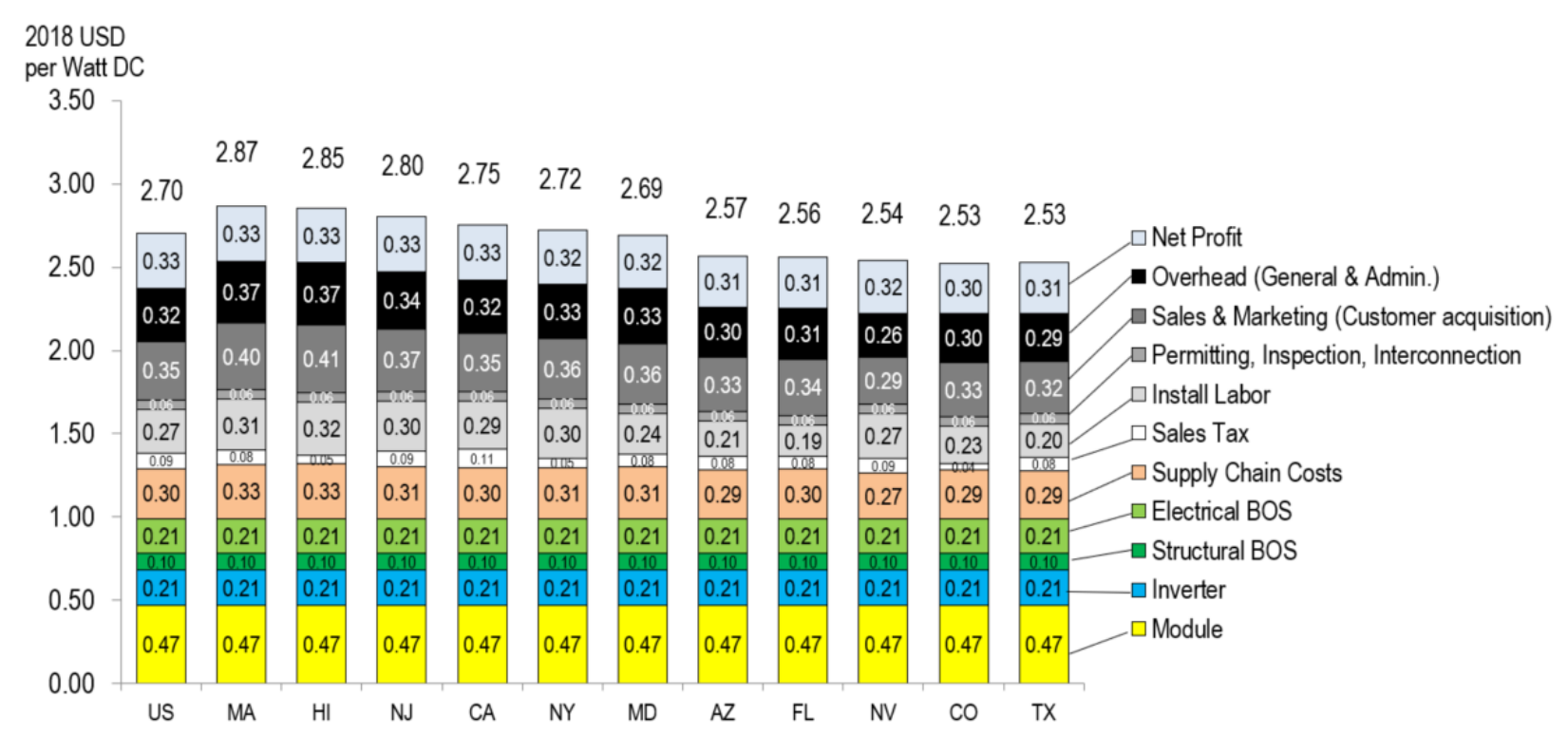

Figure 15. Q1 2018 benchmark by location: 6.2-kW residential system cost (2018 USD/Wdc)

\subsection{Residential Model Output vs. Reported Costs}

As shown in Figure 16, our bottom-up modeling approach yields a different cost structure than those reported by public solar integrators in their corporate filings ${ }^{13}$ (Sunrun 2018, Vivint Solar 2018). Because integrators sell and lease PV systems, they practice a different method of reporting costs than do businesses that only sell goods. Many of the costs for leased systems are reported over the life of the lease rather than the period in which the system is sold; therefore, it is difficult to determine the actual costs at the time of the sale. Although Sunrun and Vivint Solar report system costs in their corporate filings on a quarterly basis, the limited transparency in the public filings makes it difficult to determine the underlying costs as well as the timing of those costs. Because of the lack of transparency in the reported company costs, it is difficult to explain these differences entirely, and this topic is worthy of future research. Explanations could include the following:

1. Reported companies may spend more on customer acquisition costs to grow market share.

2. Reported companies' customer acquisition costs consist of leasing, loan, and cash purchase options. Non-cash purchase options may have higher customer acquisition costs than the cash purchase model in this report. National installers also have recently spent considerable effort retraining sales teams as they have shifted focus towards offering customers a direct ownership option, rather than a lease or PPA. Retraining a sales staff can be a multi-month process and add considerable expense (GTM and SEIA 2018). Additionally, fewer systems may be sold during the transition process, which would increase customer acquisition costs on a per watt basis.

3. Part of the difference in installation costs could come from preexisting contracts or older inventory that integrators used in systems installed in Q1 2018.

\footnotetext{
${ }^{13}$ Since the acquisition of SolarCity by Tesla, its quarterly corporate filings do not include PV cost data (Tesla 2018).
} 


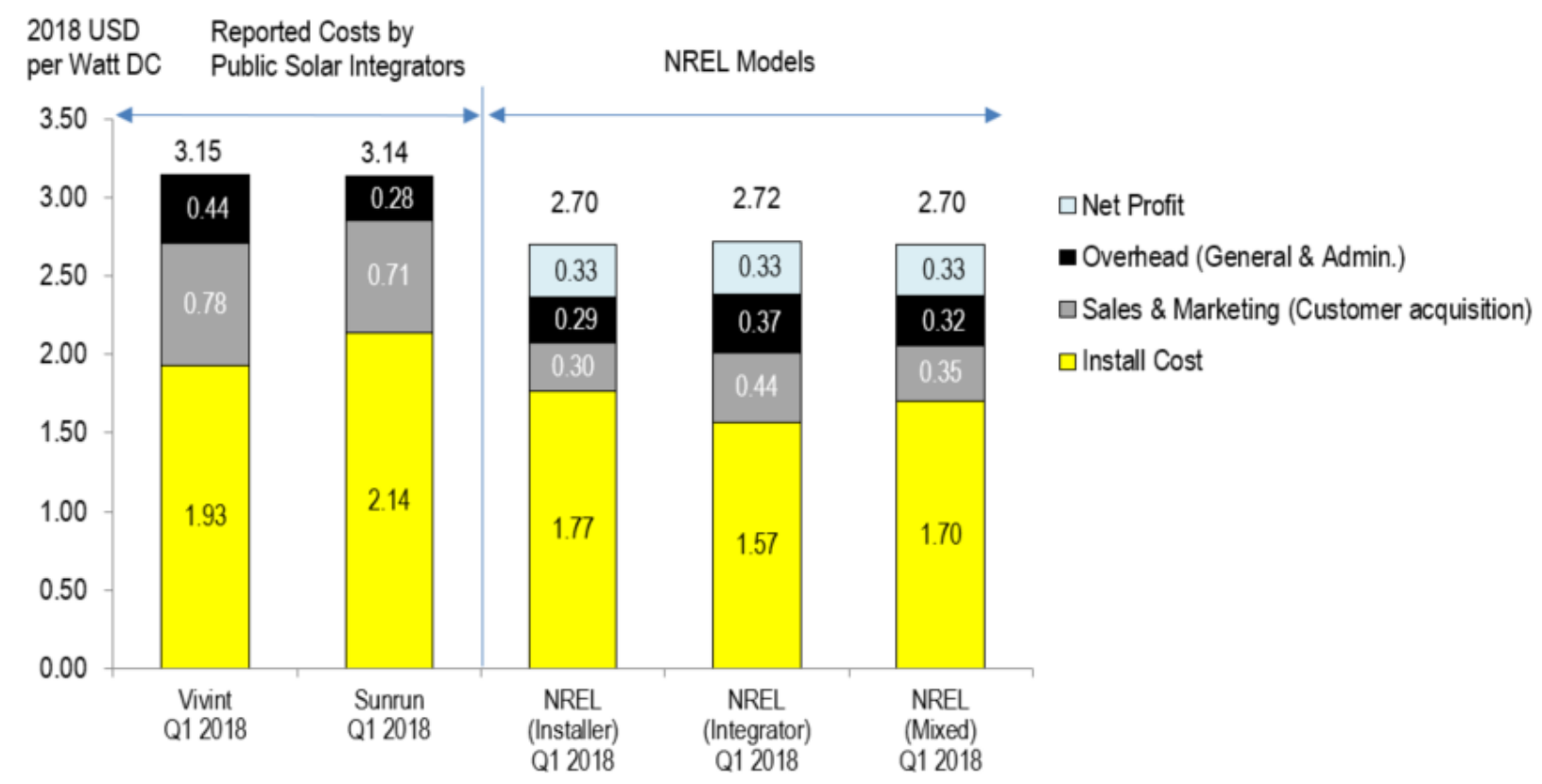

Figure 16. Q1 2018 NREL modeled cost benchmark (2018 USD/Wdc) vs. Q1 2018 companyreported costs

\subsection{Residential PV Price Benchmark Historical Trends}

NREL began benchmarking PV system costs in 2010 to track PV costs against DOE Solar Energy Technologies Office (SETO) targets and to examine cost-reduction opportunities for achieving these goals. ${ }^{14}$ Since that time, NREL has produced seven additional benchmarks, including a historical Q4 2009 benchmark. Figure 17 summarizes the reduction in residential PV system cost benchmarks between 2010 and $2018 .{ }^{15}$

\footnotetext{
14 The original overarching 2020 SETO goal for solar was to reach levelized cost parity with a new thermal plant, estimated to be $6 \varnothing / \mathrm{kWh}$ without subsidies, or a system installed cost of $\$ 1 / \mathrm{W}$. Commercial and residential PV were later separated to have their own goals of costs below retail rates, estimated to be $7 \phi / \mathrm{kWh}$ and $9 \phi / \mathrm{kWh}$, or system installed costs of $\$ 1.25 / \mathrm{W}$ and $\$ 1.50 / \mathrm{W}$, respectively (all 2020 targets are quoted in nominal USD). In recognition of the transformative solar progress to date and the potential for further innovation, in 2016 SETO extended its goals to reduce the unsubsidized cost of energy by 2030 to $3 \phi / \mathrm{kWh}, 4 \phi / \mathrm{kWh}$, and $5 \phi / \mathrm{kWh}$ for utility-scale PV, commercial PV, and residential PV (all 2030 targets are quoted in nominal USD).

${ }^{15}$ Each year's PV system cost benchmark corresponds to the NREL benchmark calculted in Q4 of the previous year or Q1 of the current year (e.g., 2010 = Q4 2009; $2017=$ Q1 2017).
} 


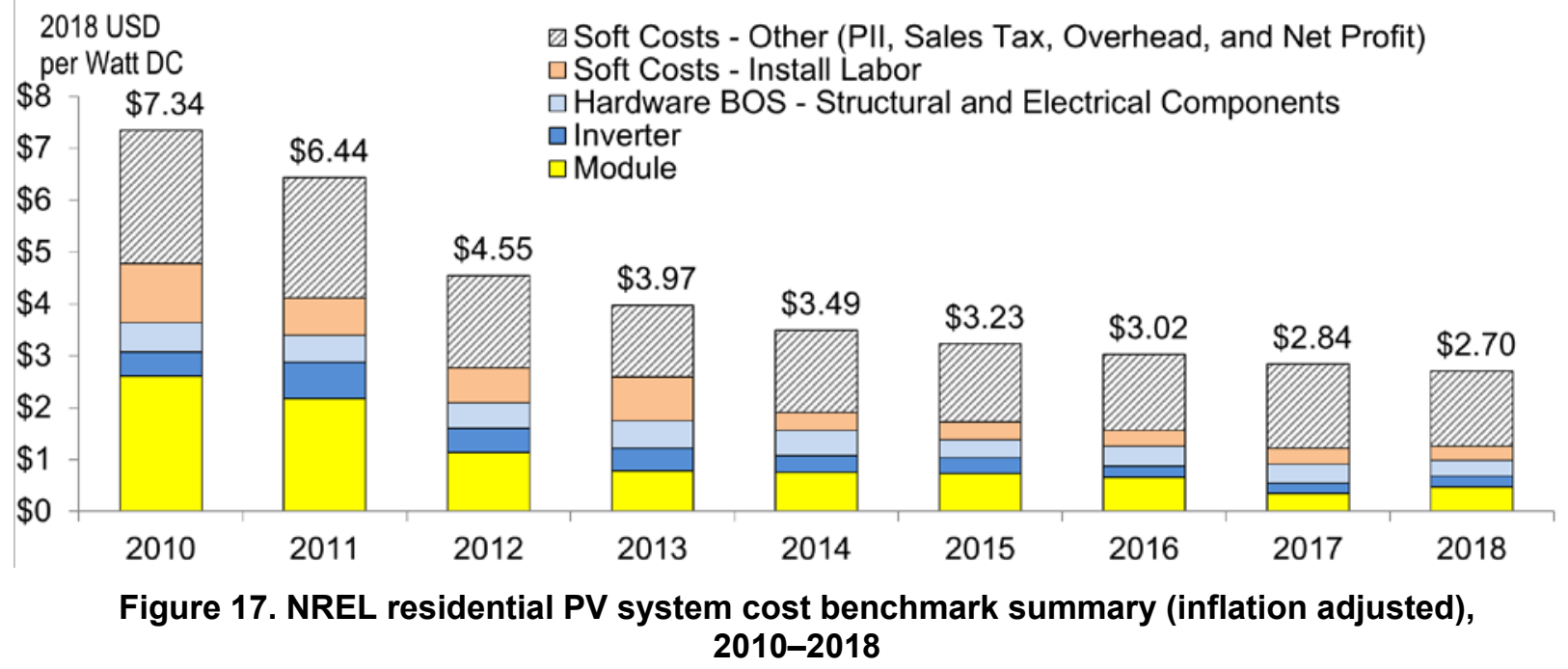

As demonstrated in Figure 17, from 2010 to 2018 there was a 63\% reduction in the residential PV system cost benchmark. Approximately $57 \%$ of that reduction can be attributed to total hardware costs (module, inverter, and hardware BOS), with module prices dropping $82 \%$ over that period. An additional $19 \%$ can be attributed to labor costs, which dropped $77 \%$ over that period. The final $24 \%$ is attributable to other soft costs, including PII, sales tax, overhead, and net profit.

From 2017 to 2018, there was a 5\% reduction in the residential PV system cost benchmark.

\subsection{Residential PV Levelized Cost of Energy Historical Trends}

Assumptions for the residential PV LCOE benchmarks from 2010 to 2018 are summarized in Table 3. In addition to a $63 \%$ reduction in installed cost from 2010 to 2018 , O\&M costs declined $60 \%$, annual degradation declined $30 \%$, equity discount rate declined $23 \%$, debt interest rate declined $13 \%$, and debt fraction increased $17 \%$. 
Table 3. Residential PV LCOE Assumptions, 2010-2018

\begin{tabular}{|c|c|c|c|c|c|c|c|c|c|}
\hline $\begin{array}{l}2018 \text { USD } \\
\text { per Watt DC }\end{array}$ & 2010 & 2011 & 2012 & 2013 & 2014 & 2015 & 2016 & 2017 & 2018 \\
\hline \multicolumn{10}{|c|}{ Benchmark report } \\
\hline $\begin{array}{l}\text { Installed } \\
\text { cost }(\$ / W)\end{array}$ & 7.34 & 6.44 & 4.55 & 3.97 & 3.49 & 3.23 & 3.02 & 2.84 & 2.70 \\
\hline $\begin{array}{l}\text { System size } \\
\text { (kw-DC) }\end{array}$ & 5.0 & 5.0 & 5.1 & 5.1 & 5.2 & 5.2 & 5.6 & 5.7 & 6.2 \\
\hline $\begin{array}{l}\text { Inverter } \\
\text { loading } \\
\text { ratio }\end{array}$ & 1.10 & 1.11 & 1.12 & 1.13 & 1.13 & 1.14 & 1.15 & 1.15 & 1.15 \\
\hline \multicolumn{10}{|c|}{ Ongoing NREL benchmarking } \\
\hline $\begin{array}{l}\text { Annual } \\
\text { degradation } \\
(\%)\end{array}$ & $1.00 \%$ & $0.95 \%$ & $0.90 \%$ & $0.85 \%$ & $0.80 \%$ & $0.75 \%$ & $0.75 \%$ & $0.75 \%$ & $0.70 \%$ \\
\hline $\begin{array}{l}\text { O\&M } \\
\text { expenses } \\
\text { (\$/kw-yr) }\end{array}$ & 54 & 48 & 41 & 36 & 30 & 25 & 25 & 24 & 22 \\
\hline $\begin{array}{l}\text { Pre-inverter } \\
\text { derate }(\%)\end{array}$ & $90.0 \%$ & $90.1 \%$ & $90.2 \%$ & $90.3 \%$ & $90.4 \%$ & $90.5 \%$ & $90.5 \%$ & $90.5 \%$ & $90.5 \%$ \\
\hline $\begin{array}{l}\text { Inverter } \\
\text { efficiency } \\
(\%)\end{array}$ & $94.0 \%$ & $94.8 \%$ & $95.6 \%$ & $96.4 \%$ & $97.2 \%$ & $98.0 \%$ & $98.0 \%$ & $98.0 \%$ & $98.0 \%$ \\
\hline $\begin{array}{l}\text { Equity } \\
\text { discount } \\
\text { rate (real) }\end{array}$ & $9.0 \%$ & $8.6 \%$ & $8.3 \%$ & $7.9 \%$ & $7.6 \%$ & $7.3 \%$ & $6.9 \%$ & $6.9 \%$ & $6.9 \%$ \\
\hline $\begin{array}{l}\text { Inflation } \\
\text { rate }\end{array}$ & $2.5 \%$ & $2.5 \%$ & $2.5 \%$ & $2.5 \%$ & $2.5 \%$ & $2.5 \%$ & $2.5 \%$ & $2.5 \%$ & $2.5 \%$ \\
\hline $\begin{array}{l}\text { Debt } \\
\text { interest rate }\end{array}$ & $5.5 \%$ & $5.4 \%$ & $5.3 \%$ & $5.2 \%$ & $5.0 \%$ & $4.9 \%$ & $4.8 \%$ & $4.8 \%$ & $4.8 \%$ \\
\hline $\begin{array}{l}\text { Debt } \\
\text { fraction }\end{array}$ & $34.2 \%$ & $35.2 \%$ & $36.1 \%$ & $37.1 \%$ & $38.1 \%$ & $39.0 \%$ & $40.0 \%$ & $40.0 \%$ & $40 \%$ \\
\hline
\end{tabular}

All 2010-2017 data are from Fu et al. (2017), adjusted for inflation. The inverter replacement line-item in Fu et al. (2017) is incorporated into O\&M expenses in this edition to be consistent with the 2018 O\&M benchmark. Other important assumptions: residential PV system LCOE assumes a 1) system lifetime of 30 years; 2) federal tax rate of $35 \%$ from 2010-2017, changing to $21 \%$ in 2018; 3) state tax rate of $7 \%$; 4) MACRS depreciation schedule; 5) no state or local subsidies; 6 ) a working capital and debt service reserve account for 6 months of operating costs and debt payments (earning an interest of $1.75 \%$ ); 7) a 3-month construction loan, with an interest rate of $4 \%$ and a fee of $1 \%$ of the cost of the system; 8) a module tilt angle of 25 degrees, and an azimuth of 180 degrees; 9 ) debt with a term of 18 years; and 10) $\$ 1.1$ million of upfront financial transaction costs for a $\$ 100$ million TPO transaction of a pool of residential projects.

Using these assumptions, we calculate the residential PV LCOE-with and without the 30\% federal investment tax credit (ITC) - in Phoenix (high solar resource), Kansas City (medium), and New York City (low), corresponding to the locations used to calculate LCOE in the SunShot Vision Study (U.S. DOE 2012) (Figure 18). ${ }^{16}$ From 2010 to 2018, residential PV LCOE declined $71 \%$ (6\% between 2017 and 2018), resulting in an unsubsidized LCOE of $\$ 0.12-\$ 0.16 / \mathrm{kWh}$ (\$0.08-\$0.10/kWh when including the federal ITC). This reduction is $89 \%$ toward achieving SETO’s 2020 residential PV LCOE goal. ${ }^{17}$

\footnotetext{
${ }^{16}$ Because this analysis uses a more robust set of current and historical assumptions, LCOE values may differ from previously reported benchmarked values.

${ }^{17}$ In 2018 USD, the 2020 SETO target is $\$ 0.10 / \mathrm{kWh}$, and the residential LCOE in Kansas City (without the ITC) is $\$ 0.51 / \mathrm{kWh}$ in 2010 and $\$ 0.15 / \mathrm{kWh}$ in 2018; see Appendix A. Progress toward the SETO target is calculated as follows: $(0.507-0.147) /(0.507-0.102)=89 \%$.
} 


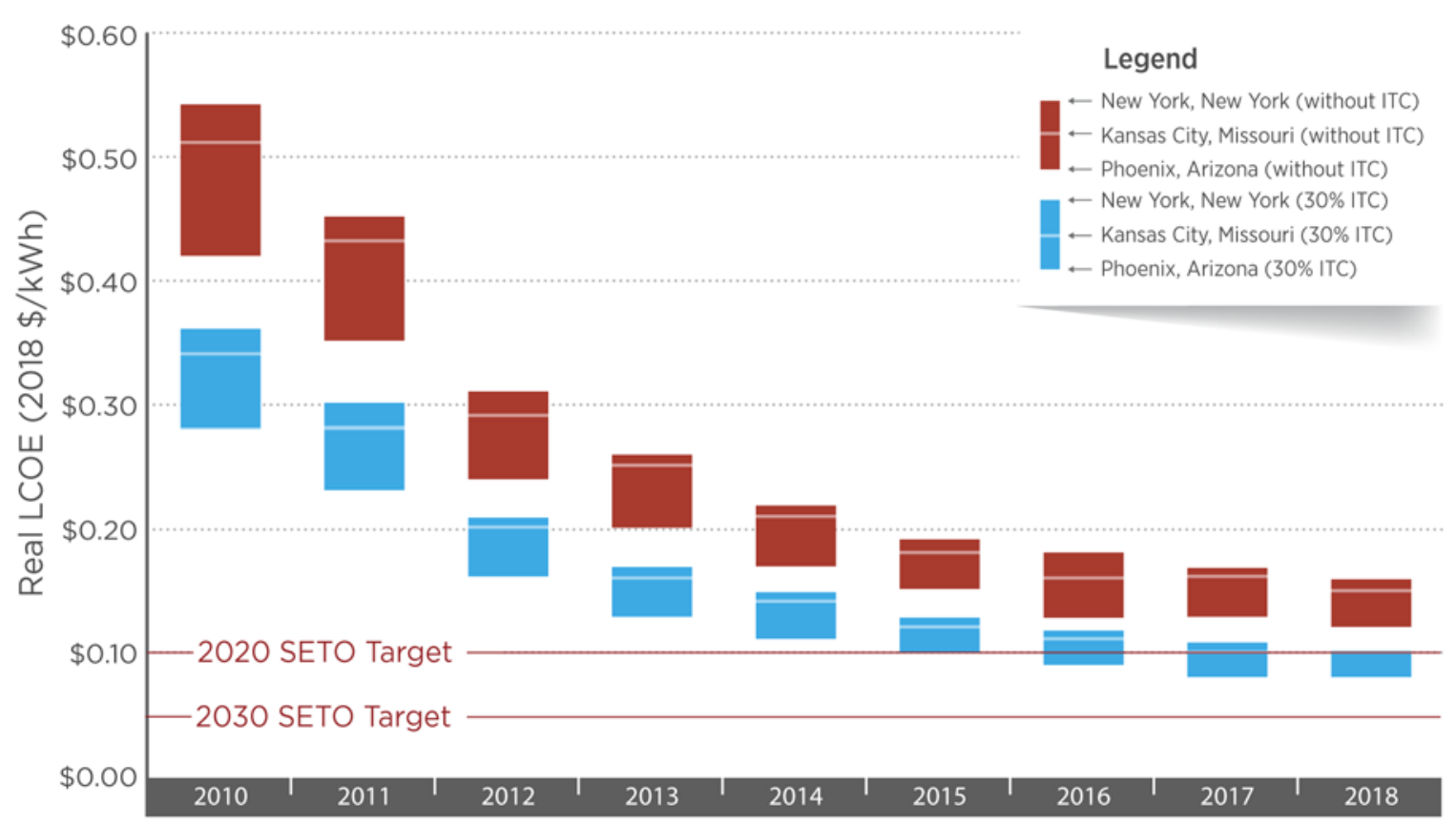

Figure 18. LCOE for residential PV systems, by region, with and without ITC, 2010-2018 


\section{Commercial PV Model}

This section describes our commercial model's structure, inputs, and assumptions (Section 4.1) and output (Section 4.2) as well as historical PV price (Section 4.3) and LCOE (Section 4.4) trends.

\subsection{Commercial Model Structure, Inputs, and Assumptions}

We model a 200-kW, 1,000-volt DC (Vdc), commercial-scale flat-roof system using multicrystalline 19.1\%-efficient modules from a Tier 1 supplier, three-phase string inverters, and a ballasted racking solution on a membrane roof. A penetrating PV mounting system can have higher energy yield ( $\mathrm{kWh}$ per $\mathrm{kW}$ ) owing to wider tilt-angle range allowance. However, we do not model this system type, because its market share has declined owing to additional required flashing and sealing work, roof warranty issues, and the relative difficulty of replacing such a system in the future. Figure 19 presents a schematic of our commercial-scale system cost model. Table 4 presents the detailed modeling inputs and assumptions. We separate our cost estimate into EPC and project-development functions. Although some firms engage in both activities in an integrated manner, and potentially achieve lower cost and pricing by reducing the total margin across functions, we believe the distinction can help separate and highlight the specific cost trends and drivers associated with each function.

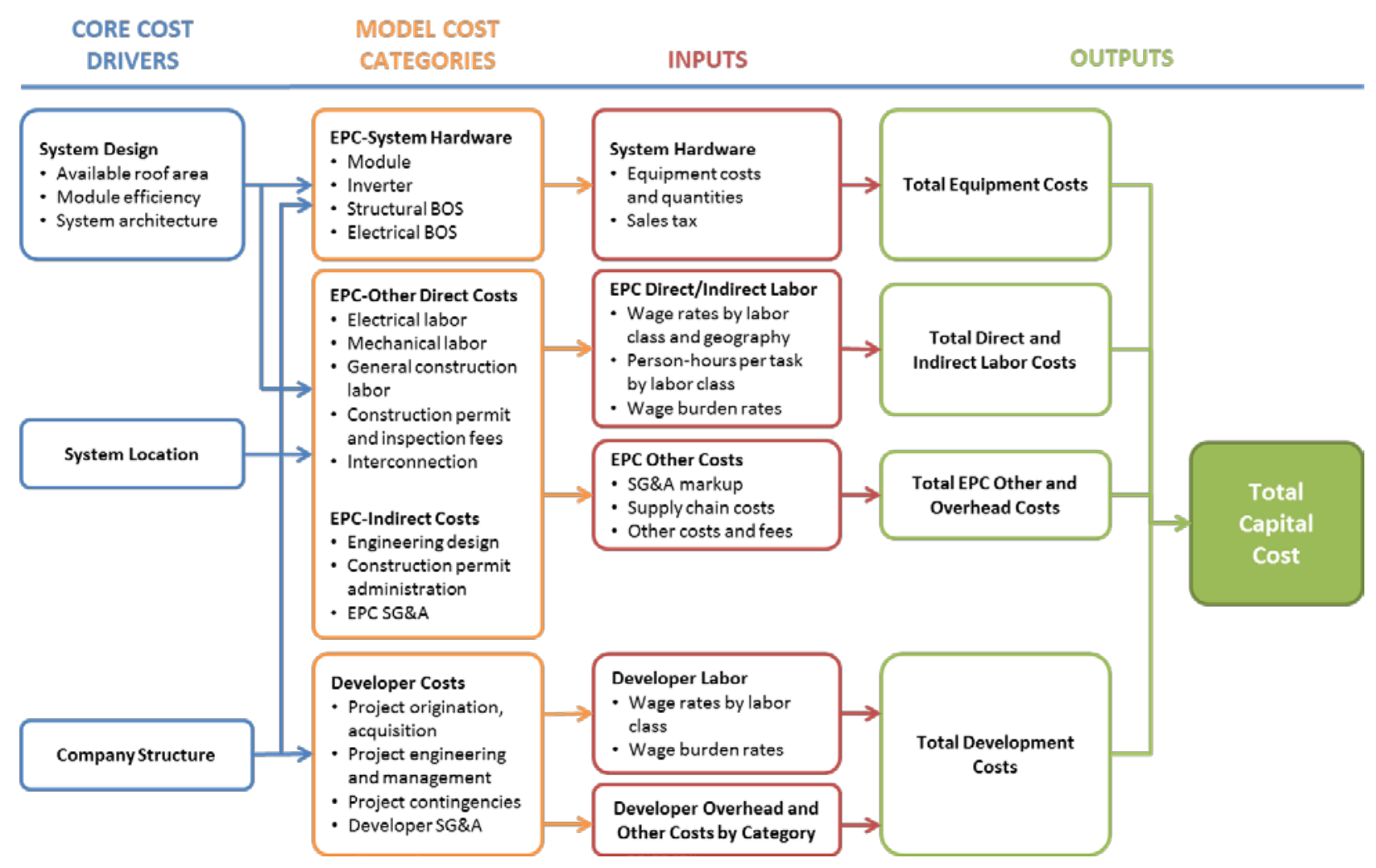

Figure 19. Commercial PV: model structure 
Table 4. Commercial PV: Modeling Inputs and Assumptions

\begin{tabular}{|c|c|c|c|}
\hline Category & Modeled Value & Description & Sources \\
\hline System size & $100 \mathrm{~kW}-1 \mathrm{MW}$ & Average installed size per system & Go Solar CA (2018) \\
\hline Module efficiency & $19.1 \%$ & Average module efficiency & Go Solar CA (2018) \\
\hline Module price & $\$ 0.47 / \mathrm{Wdc}$ & Ex-factory gate (first buyer) ASP, Tier 1 modules & $\begin{array}{l}\text { GTM and SEIA (2018), NREL } \\
(2018)\end{array}$ \\
\hline Inverter price & $\begin{array}{l}\text { Three-phase string } \\
\text { inverter: } \$ 0.08 / \text { Wdc }\end{array}$ & $\begin{array}{l}\text { Ex-factory gate prices (first buyer) ASP, Tier } 1 \\
\text { inverters }\end{array}$ & PVinsights (2018), NREL (2018) \\
\hline $\begin{array}{l}\text { Structural } \\
\text { components } \\
\text { (racking) }\end{array}$ & $\begin{array}{l}\$ 0.10-\$ 0.22 / \mathrm{Wdc} \text {; varies } \\
\text { by location due to wind and } \\
\text { snow loading }\end{array}$ & $\begin{array}{l}\text { Ex-factory gate prices; flat-roof ballasted racking } \\
\text { system }\end{array}$ & $\begin{array}{l}\text { ASCE (2006), model } \\
\text { assumptions, NREL (2018) }\end{array}$ \\
\hline $\begin{array}{l}\text { Electrical } \\
\text { components }\end{array}$ & $\begin{array}{l}\$ 0.13-\$ 0.17 / \mathrm{Wdc} \text {; varies } \\
\text { by location due to cost of } \\
\text { doing business }\end{array}$ & $\begin{array}{l}\text { Conductors, conduit and fittings, transition boxes, } \\
\text { switchgear, panel boards, etc. }\end{array}$ & $\begin{array}{l}\text { Model assumptions, NREL } \\
\text { (2018), RSMeans (2018) }\end{array}$ \\
\hline $\begin{array}{l}\text { EPC overhead }(\% \\
\text { of equipment } \\
\text { costs) }\end{array}$ & $13 \%$ & $\begin{array}{l}\text { Costs and fees associated with EPC overhead, } \\
\text { inventory, shipping, and handling }\end{array}$ & NREL (2018) \\
\hline Sales tax & Varies by location & $\begin{array}{l}\text { Sales tax on equipment costs; national benchmark } \\
\text { applies an average (by state) weighted by } 2017 \\
\text { installed capacities }\end{array}$ & $\begin{array}{l}\text { RSMeans (2018), GTM and SEIA } \\
(2018)\end{array}$ \\
\hline \multirow[t]{2}{*}{$\begin{array}{l}\text { Direct installation } \\
\text { labor }\end{array}$} & $\begin{array}{l}\text { Electrician: } \$ 19.74-\$ 38.96 \\
\text { per hour; } \\
\text { Laborer: } \$ 12.88-\$ 25.57 \\
\text { per hour; }\end{array}$ & \multirow[t]{2}{*}{$\begin{array}{l}\text { Modeled labor rate assumes non-union labor and } \\
\text { depends on state; national benchmark uses } \\
\text { weighted average of state rates }\end{array}$} & \multirow[t]{2}{*}{ BLS (2018), NREL (2018) } \\
\hline & Varies by location & & \\
\hline $\begin{array}{l}\text { Burden rates }(\% \text { of } \\
\text { direct labor) }\end{array}$ & $\begin{array}{l}\text { Total nationwide average: } \\
31.8 \%\end{array}$ & $\begin{array}{l}\text { Workers compensation (state-weighted average), } \\
\text { federal and state unemployment insurance, FICA, } \\
\text { builders' risk, public liability }\end{array}$ & RSMeans (2018) \\
\hline PII & $\$ 0.10 / \mathrm{Wdc}$ & $\begin{array}{l}\text { For construction permits fee, interconnection study } \\
\text { fees for existing substation, testing, and } \\
\text { commissioning }\end{array}$ & NREL (2018) \\
\hline $\begin{array}{l}\text { Developer } \\
\text { overhead }\end{array}$ & $\begin{array}{l}\text { Assume 10-MW system } \\
\text { development and } \\
\text { installation per year for a } \\
\text { typical developer }\end{array}$ & $\begin{array}{l}\text { Includes fixed overhead expenses such as payroll, } \\
\text { facilities, travel, insurance, administrative, business } \\
\text { development, finance, and other corporate functions; } \\
\text { assumes } 10 \mathrm{MW} / \mathrm{year} \text { of system sales }\end{array}$ & Model assumptions, NREL (2018) \\
\hline Contingency & $4 \%$ & $\begin{array}{l}\text { Estimated as markup on EPC cost; value represents } \\
\text { actual cost overruns above estimated cost }\end{array}$ & NREL (2018) \\
\hline Profit & $7 \%$ & $\begin{array}{l}\text { Applies a fixed percentage margin to all costs } \\
\text { including hardware, installation labor, EPC } \\
\text { overhead, developer overhead, etc. }\end{array}$ & NREL (2018) \\
\hline
\end{tabular}

\subsection{Commercial Model Output}

Figure 20 presents the U.S. national benchmark from our commercial model. As in the residential model, the national benchmark represents an average weighted by 2017 stateinstalled capacities. We model different system sizes because of the wide scope of the "commercial" sector, which comprises a diverse customer base occupying a variety of building sizes. Economies of scale - driven by hardware, labor, and related markups - are evident here. As system sizes increase, the per-watt cost to build them decreases. This holds even as we assume that a typical developer has $10 \mathrm{MW}$ of system development and installation per year, and therefore has overhead on this $10 \mathrm{MW}$ total capacity that does not vary for different system sizes. 
When a developer installs more capacity annually, the developer's overhead per watt in each system declines (shown in Figure 18 in our Q1 2015 benchmark report, Chung et al. 2015).

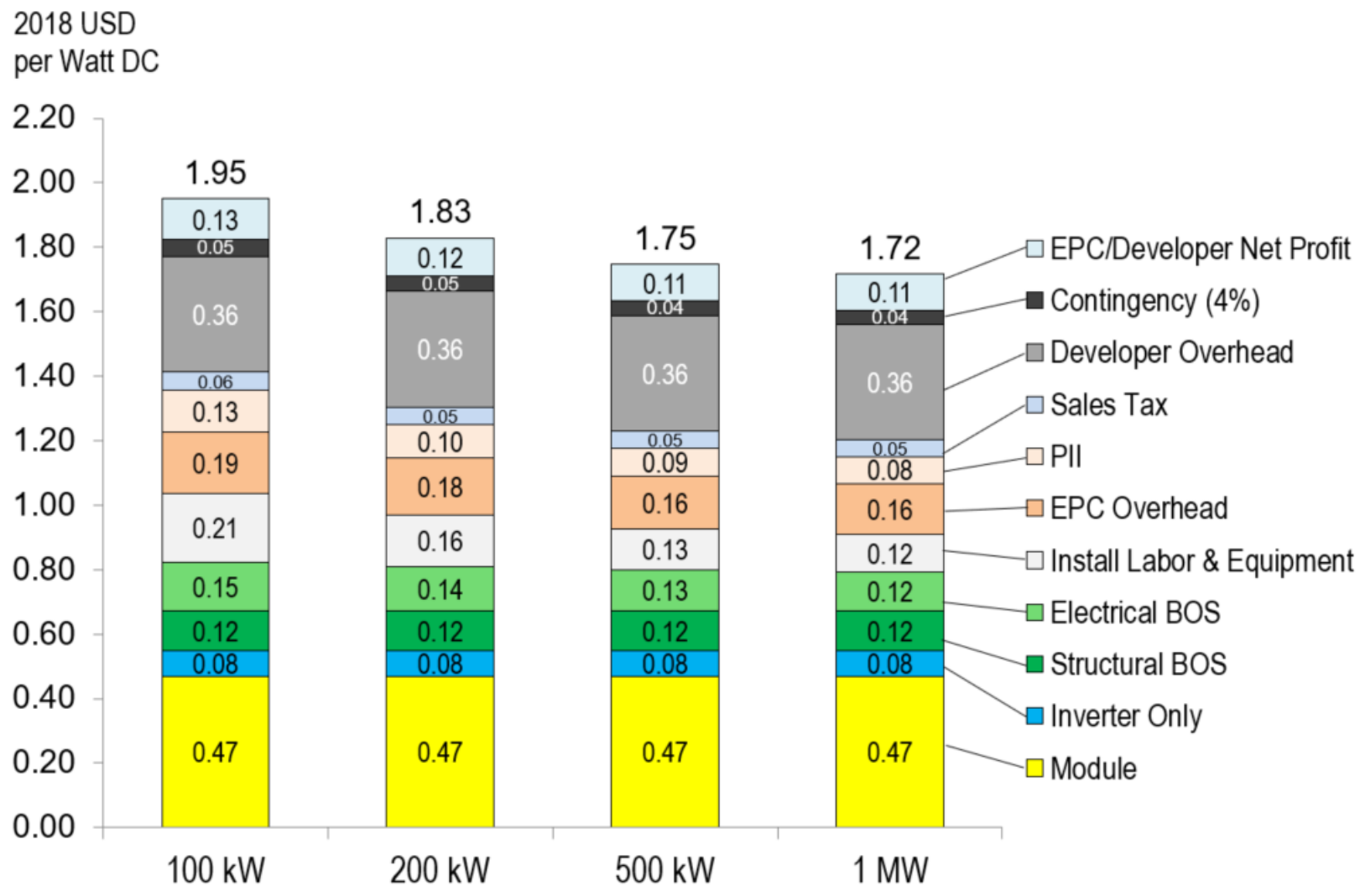

Figure 20. Q1 2018 U.S. benchmark: commercial PV system cost (2018 USD/Wdc)

Figure 21 presents the benchmark from our commercial model by location in the top U.S. PV markets (by 2017 installations). The main cost drivers for different regions in the commercial PV market are the same as in the residential model (labor rates, sales tax, and cost of doing business index), but also include costs associated with wind or snow loading. 


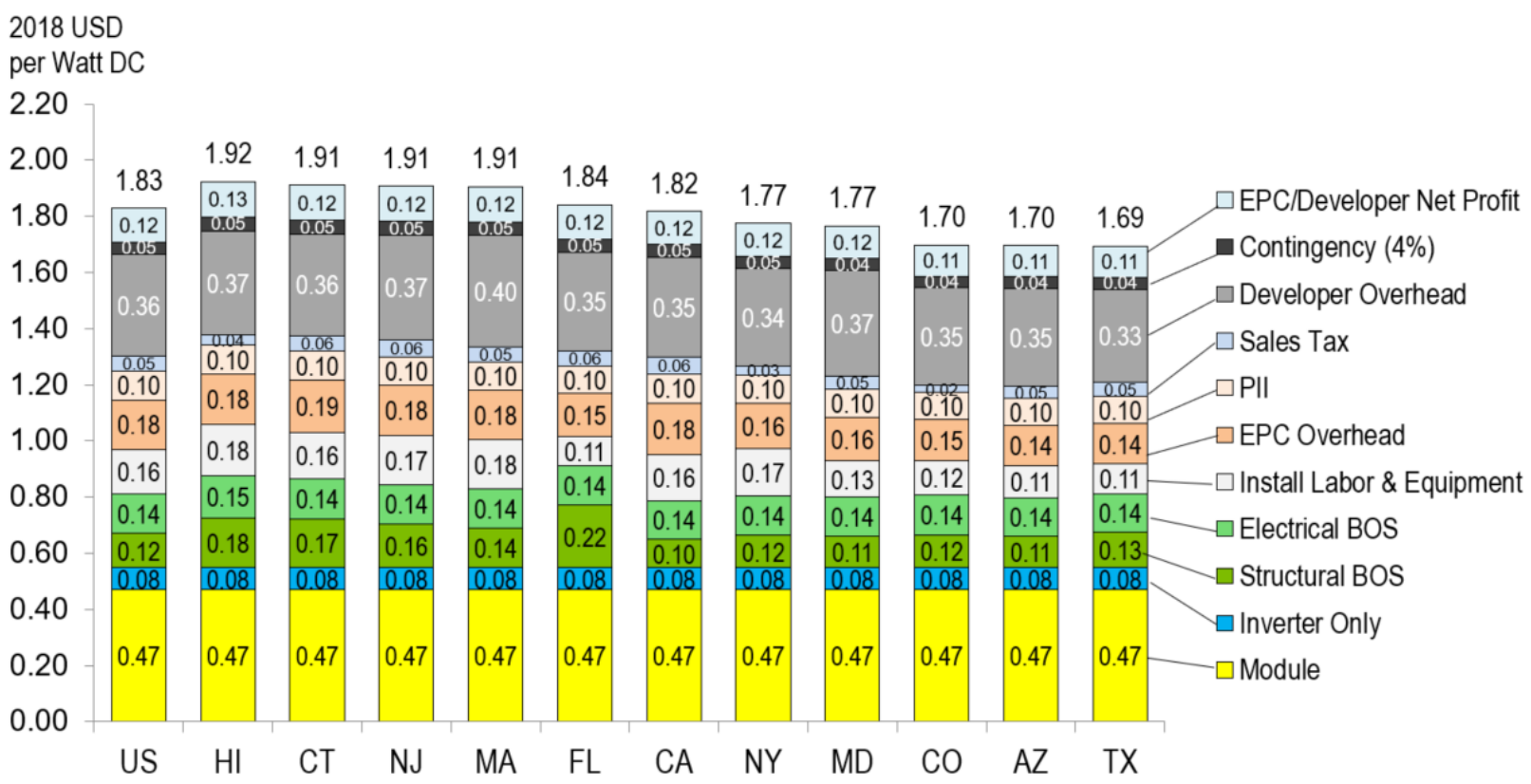

Figure 21. Q1 2018 benchmark by location: 200-kW commercial PV system cost (2018 USD/Wdc)

\subsection{Commercial PV Price Benchmark Historical Trends}

Figure 22 shows the $66 \%$ reduction in commercial PV system cost benchmarks between 2010 and $2018 .{ }^{18}$ Approximately $79 \%$ of that reduction can be attributed to total hardware costs (module, inverter, and hardware BOS), with module prices dropping $82 \%$ over that period. An additional $5 \%$ can be attributed to labor, which dropped $50 \%$ over that period. The final $16 \%$ is attributable to other soft costs, including PII, sales tax, overhead, and net profit.

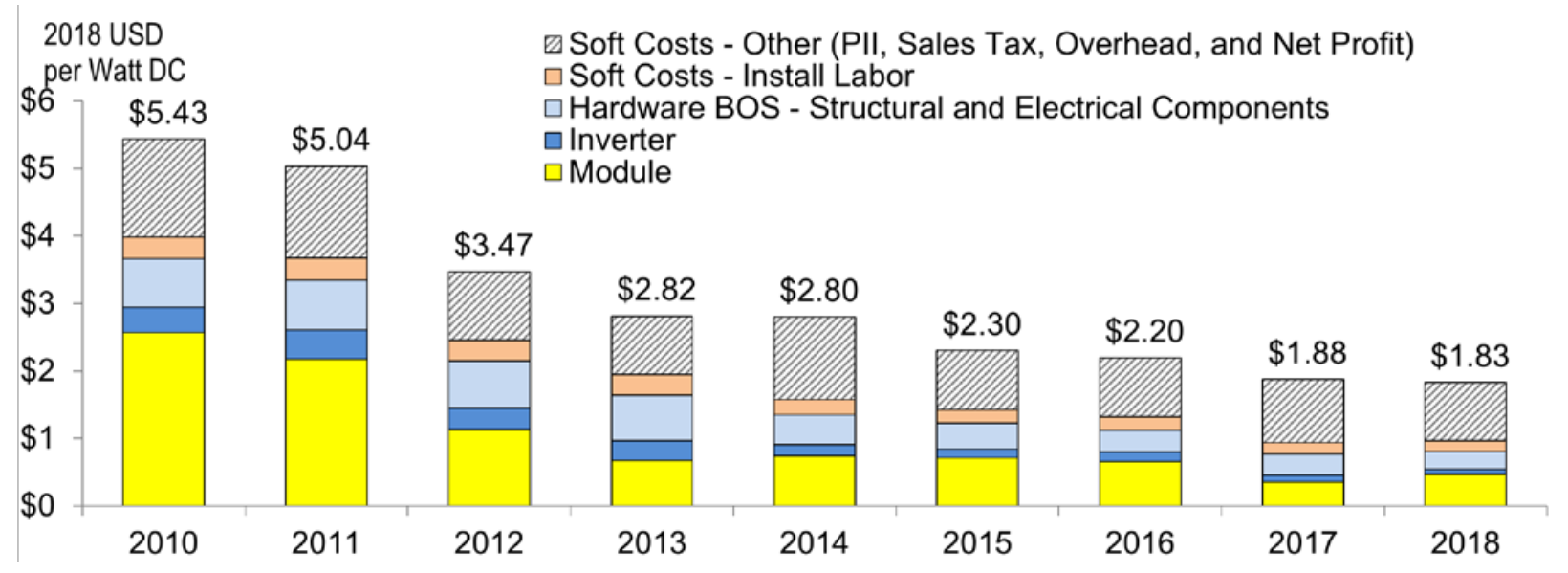

Figure 22. NREL commercial PV system cost benchmark summary (inflation adjusted), 2010-2018

\footnotetext{
${ }^{18}$ Each year's PV system cost benchmark corresponds to the NREL benchmark calculated in Q4 of the previous year or Q1 of the current year (e.g., $2010=$ Q4 2009; $2017=$ Q1 2017).
} 
From 2017 to 2018, there was a 3\% reduction in the commercial PV system cost benchmark. Cost reductions in most categories were moderated by a $32 \%$ increase in module spot price.

\subsection{Commercial PV Levelized Cost of Energy Historical Trends}

Assumptions for the commercial PV LCOE benchmarks from 2010 to 2018 are summarized in Table 5. In addition to a $66 \%$ reduction in installed cost from 2010 to 2018 , O\&M costs declined $47 \%$, annual degradation declined $30 \%$, equity discount rate declined $23 \%$, debt interest rate declined $13 \%$, and debt fraction increased $17 \%$.

Table 5. Commercial PV LCOE Assumptions, 2010-2018

\begin{tabular}{|c|c|c|c|c|c|c|c|c|c|}
\hline $\begin{array}{l}2018 \text { USD } \\
\text { per Watt DC }\end{array}$ & 2010 & 2011 & 2012 & 2013 & 2014 & 2015 & 2016 & 2017 & 2018 \\
\hline \multicolumn{10}{|c|}{ Benchmark report } \\
\hline $\begin{array}{l}\text { Installed cost } \\
(\$ / W)\end{array}$ & 5.43 & 5.04 & 3.47 & 2.82 & 2.80 & 2.30 & 2.20 & 1.88 & 1.83 \\
\hline $\begin{array}{l}\text { System size } \\
\text { (kw-DC) }\end{array}$ & 200 & 200 & 200 & 200 & 200 & 200 & 200 & 200 & 200 \\
\hline $\begin{array}{l}\text { Inverter } \\
\text { loading ratio }\end{array}$ & 1.10 & 1.11 & 1.12 & 1.13 & 1.13 & 1.14 & 1.15 & 1.15 & 1.15 \\
\hline \multicolumn{10}{|c|}{ Ongoing NREL benchmarking } \\
\hline $\begin{array}{l}\text { Annual } \\
\text { degradation } \\
(\%)\end{array}$ & $1.00 \%$ & $0.95 \%$ & $0.90 \%$ & $0.85 \%$ & $0.80 \%$ & $0.75 \%$ & $0.75 \%$ & $0.75 \%$ & $0.70 \%$ \\
\hline $\begin{array}{l}\text { O\&M } \\
\text { expenses } \\
\text { (\$/kw-yr) }\end{array}$ & 33 & 30 & 28 & 25 & 22 & 19 & 19 & 18 & 18 \\
\hline $\begin{array}{l}\text { Pre-inverter } \\
\text { derate (\%) }\end{array}$ & $90.5 \%$ & $90.5 \%$ & $90.5 \%$ & $90.5 \%$ & $90.5 \%$ & $90.5 \%$ & $90.5 \%$ & $90.5 \%$ & $90.5 \%$ \\
\hline $\begin{array}{l}\text { Inverter } \\
\text { efficiency (\%) }\end{array}$ & $95.0 \%$ & $95.6 \%$ & $96.2 \%$ & $96.8 \%$ & $97.4 \%$ & $98.0 \%$ & $98.0 \%$ & $98.0 \%$ & $98.0 \%$ \\
\hline $\begin{array}{l}\text { Equity } \\
\text { discount rate } \\
\text { (real) }\end{array}$ & $9.0 \%$ & $8.6 \%$ & $8.3 \%$ & $7.9 \%$ & $7.6 \%$ & $7.3 \%$ & $6.9 \%$ & $6.9 \%$ & $6.9 \%$ \\
\hline Inflation rate & $2.5 \%$ & $2.5 \%$ & $2.5 \%$ & $2.5 \%$ & $2.5 \%$ & $2.5 \%$ & $2.5 \%$ & $2.5 \%$ & $2.5 \%$ \\
\hline $\begin{array}{l}\text { Debt interest } \\
\text { rate }\end{array}$ & $5.5 \%$ & $5.4 \%$ & $5.3 \%$ & $5.2 \%$ & $5.0 \%$ & $4.9 \%$ & $4.8 \%$ & $4.8 \%$ & $4.8 \%$ \\
\hline Debt fraction & $34.2 \%$ & $35.2 \%$ & $36.1 \%$ & $37.1 \%$ & $38.1 \%$ & $39.0 \%$ & $40.0 \%$ & $40.0 \%$ & $40 \%$ \\
\hline
\end{tabular}

All 2010-2017 data are from Fu et al. (2017), adjusted for inflation. The inverter replacement line-item in Fu et al. (2017) is incorporated into O\&M expenses in this edition to be consistent with the 2018 O\&M benchmark. Other important assumptions: commercial PV system LCOE assumes a 1) system lifetime of 30 years; 2) federal tax rate of $35 \%$ from $2010-2017$, changing to $21 \%$ in 2018 ; 3) state tax rate of $7 \%$; 4) MACRS depreciation schedule; 5 ) no state or local subsidies; 6 ) a working capital and debt service reserve account for 6 months of operating costs and debt payments (earning an interest of $1.75 \%$ ); 7 ) a 6 -month construction loan, with an interest rate of $4 \%$ and a fee of $1 \%$ of the cost of the system; 8) a system size of $200 \mathrm{~kW} ; 9$ ) an inverter lifetime of 15 years; 10) a module tilt angle of 10 degrees and an azimuth of 180 degrees; 11) debt with a term of 18 years; and 12) \$1.1 million of upfront financial transaction costs for a $\$ 100$ million TPO transaction of a pool of commercial projects. 
Using these assumptions, we calculate the commercial PV LCOE-with and without the 30\% federal ITC - in Phoenix (high solar resource), Kansas City (medium), and New York City (low), corresponding to the locations used to calculate LCOE in the SunShot Vision Study (U.S. DOE 2012) (Figure 23). ${ }^{19}$ From 2010 to 2018, commercial PV LCOE declined 72\% (3\% between 2017 and 2018), resulting in an unsubsidized LCOE of $\$ 0.09-\$ 0.12 / \mathrm{kWh}(\$ 0.06-$ $\$ 0.08 / \mathrm{kWh}$ when including the federal ITC). This reduction is $91 \%$ toward achieving SETO's 2020 commercial PV LCOE goal. ${ }^{20}$

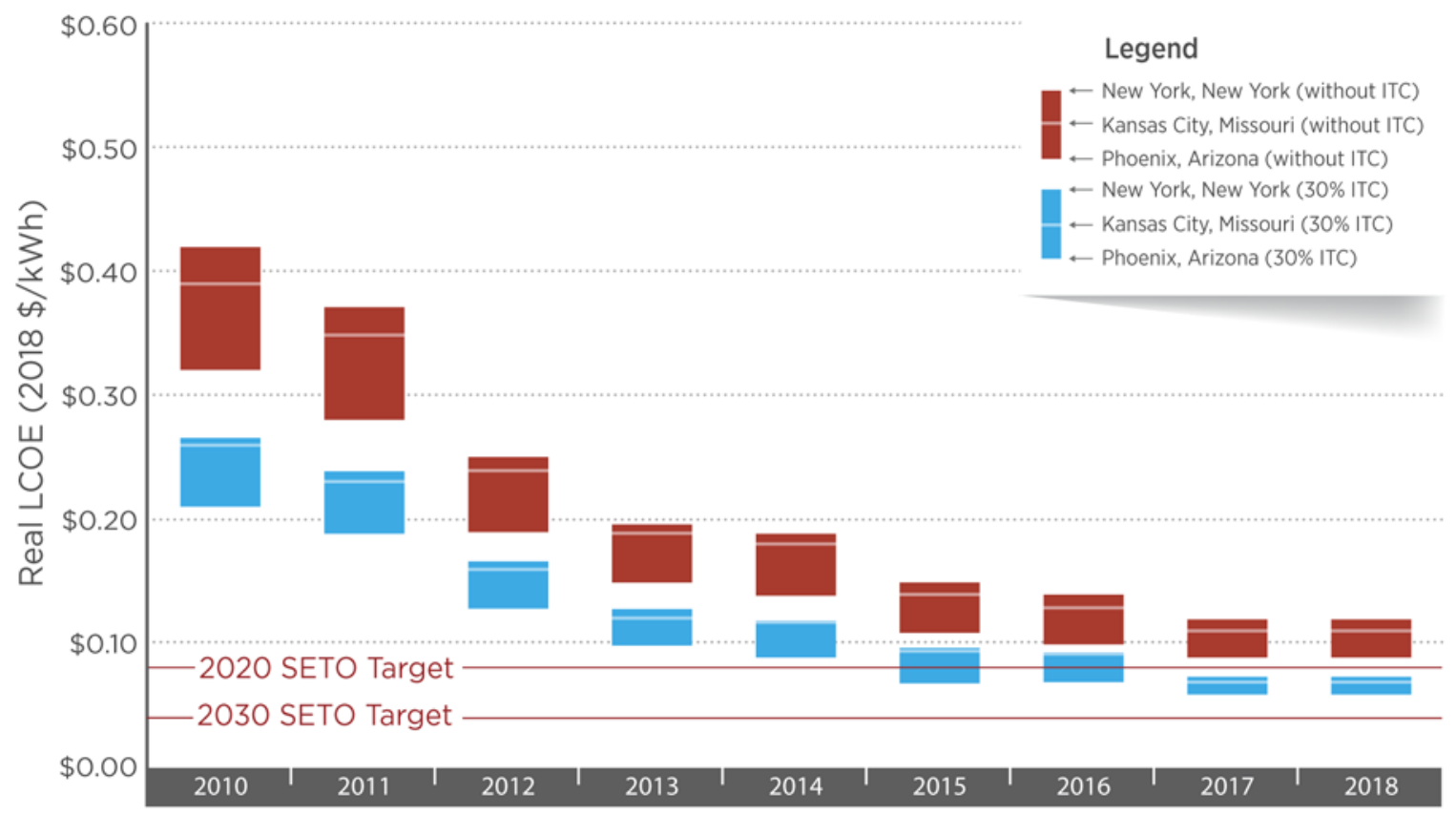

Figure 23. LCOE for commercial PV systems, by region, with and without ITC, 2010-2018

\footnotetext{
${ }^{19}$ Because this analysis uses a more robust set of current and historical assumptions, LCOE values may differ from previously reported benchmarked values.

${ }^{20}$ In 2018 USD, the 2020 SETO target is $\$ 0.08 / \mathrm{kWh}$, and the commercial LCOE in Kansas City (without the ITC) is $\$ 0.39 / \mathrm{kWh}$ in 2010 and $\$ 0.11 / \mathrm{kWh}$ in 2018 ; see Appendix A. Progress toward the SETO target is calculated as follows: $(0.393-0.109) /(0.393-0.079)=91 \%$.
} 


\section{Utility-Scale PV Model}

This section describes our utility-scale model's structure, inputs, and assumptions (Section 5.1) and output (Section 5.2) as well as historical PV price (Section 5.3) and LCOE (Section 5.4) trends.

\subsection{Utility-Scale Model Structure, Inputs, and Assumptions}

We model a baseline 100-MW, 1,000-Vdc utility-scale system using 72-cell, multicrystalline 19.1\%-efficient modules from a Tier 1 supplier and three-phase central inverters. We model both fixed-tilt and one-axis tracking on ground-mounted racking systems using driven-pile foundations. In addition, we separate our cost estimate into EPC and project-development functions. Although some firms engage in both activities in an integrated manner, we believe the distinction can help separate and highlight the specific cost trends and drivers associated with each function. Figure 24 presents a schematic of our utility-scale system cost model, and Table 6 details its assumptions and inputs.

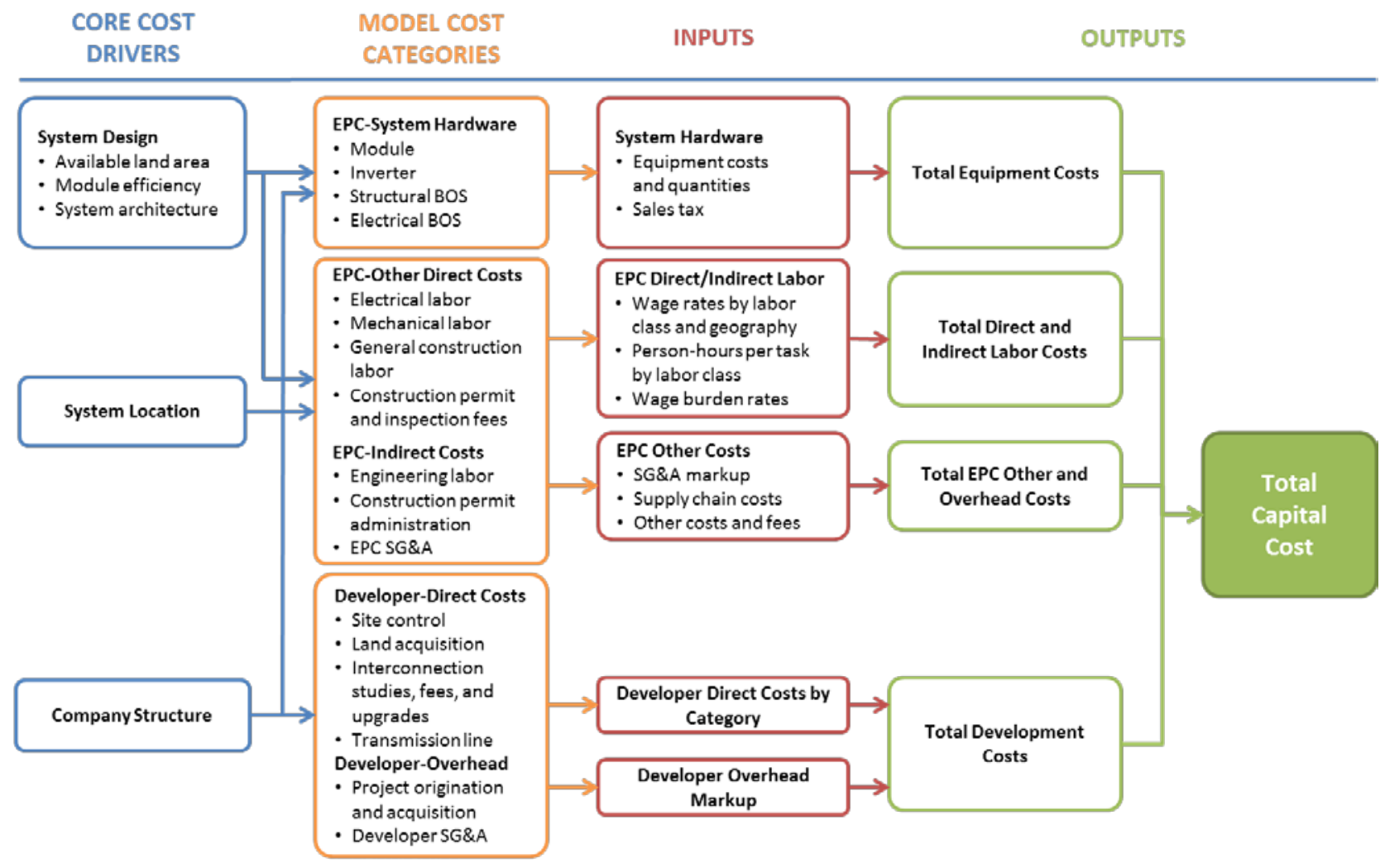

Figure 24. Utility-scale PV: model structure 
Table 6. Utility-Scale PV: Modeling Inputs and Assumptions

\begin{tabular}{|c|c|c|c|}
\hline Category & Modeled Value & Description & Sources \\
\hline System size & 5-100 MW & A large utility-scale system capacity & Model assumption \\
\hline $\begin{array}{l}\text { Module } \\
\text { efficiency }\end{array}$ & $19.1 \%$ & Average module efficiency & NREL (2018) \\
\hline Module price & $\$ 0.47 / \mathrm{Wdc}$ & $\begin{array}{l}\text { Ex-factory gate (first buyer) price, Tier } 1 \\
\text { modules }\end{array}$ & $\begin{array}{l}\text { GTM and SEIA (2018), NREL } \\
(2018)\end{array}$ \\
\hline \multirow{2}{*}{ Inverter price } & $\$ 0.04 / \mathrm{Wdc}$ (fixed-tilt) & $\begin{array}{l}\text { Ex-factory gate (first buyer) price, Tier } 1 \\
\text { inverters }\end{array}$ & \multirow{2}{*}{$\begin{array}{l}\text { Bloomberg (2018), Bolinger } \\
\text { and Seel (2018), NREL (2018) }\end{array}$} \\
\hline & $\begin{array}{l}\$ 0.05 / \mathrm{Wdc} \text { (one-axis } \\
\text { tracker) }\end{array}$ & $\begin{array}{l}\text { DC-to-AC ratio }=1.36 \text { for fixed-tilt and } 1.30 \\
\text { for one-axis tracker }\end{array}$ & \\
\hline $\begin{array}{l}\text { Structural } \\
\text { components } \\
\text { (racking) }\end{array}$ & $\begin{array}{l}\$ 0.10-\$ 0.21 / \mathrm{Wdc} \text { for } \\
\text { a } 100-\mathrm{MW} \text { system; } \\
\text { varies by location and } \\
\text { system size }\end{array}$ & Fixed-tilt racking or one-axis tracking system & $\begin{array}{l}\text { ASCE (2006), model } \\
\text { assumptions, NREL (2018) }\end{array}$ \\
\hline $\begin{array}{l}\text { Electrical } \\
\text { components }\end{array}$ & $\begin{array}{l}\text { Varies by location } \\
\text { and system size }\end{array}$ & $\begin{array}{l}\text { Our model has been upgraded to } 1,500 \mathrm{Vdc} \\
\text { system, including conductors, conduit and } \\
\text { fittings, transition boxes, switchgear, panel } \\
\text { boards, onsite transmission, etc. }\end{array}$ & $\begin{array}{l}\text { Model assumptions, NREL } \\
\text { (2018), RSMeans (2018) }\end{array}$ \\
\hline $\begin{array}{l}\text { EPC overhead } \\
\text { (\% of } \\
\text { equipment } \\
\text { costs) }\end{array}$ & $\begin{array}{l}8.67 \%-13 \% \text { for } \\
\text { equipment and } \\
\text { material (except for } \\
\text { transmission line } \\
\text { costs); } 23 \%-69 \% \text { for } \\
\text { labor costs; varies by } \\
\text { system size, labor } \\
\text { activity, and location }\end{array}$ & $\begin{array}{l}\text { Costs associated with EPC SG\&A, } \\
\text { warehousing, shipping, and logistics }\end{array}$ & NREL (2018) \\
\hline Sales tax & Varies by location & $\begin{array}{l}\text { National benchmark applies an average (by } \\
\text { state) weighted by } 2017 \text { installed capacities }\end{array}$ & $\begin{array}{l}\text { RSMeans (2018), GTM and } \\
\text { SEIA (2018) }\end{array}$ \\
\hline \multirow{2}{*}{$\begin{array}{l}\text { Direct } \\
\text { installation } \\
\text { labor }\end{array}$} & $\begin{array}{l}\text { Electrician: } \$ 19.74- \\
\$ 38.96 \text { per hour; }\end{array}$ & \multirow{2}{*}{$\begin{array}{l}\text { Modeled labor rate assumes both non-union } \\
\text { and union labor and depends on state; } \\
\text { national benchmark uses weighted average } \\
\text { of state rates }\end{array}$} & \multirow[b]{2}{*}{ BLS (2018), NREL (2018) } \\
\hline & $\begin{array}{l}\text { Laborer: } \$ 12.88- \\
\$ 25.57 \text { per hour; } \\
\text { Varies by location }\end{array}$ & & \\
\hline $\begin{array}{l}\text { Burden rates } \\
\text { (\% of direct } \\
\text { labor) }\end{array}$ & $\begin{array}{l}\text { Total nationwide } \\
\text { average: } 31.8 \%\end{array}$ & $\begin{array}{l}\text { Workers compensation (state-weighted } \\
\text { average), federal and state unemployment } \\
\text { insurance, FICA, builders' risk, public liability }\end{array}$ & RSMeans (2018) \\
\hline PII & $\begin{array}{l}\$ 0.03-\$ 0.09 / \mathrm{Wdc} \\
\text { Varies by system size } \\
\text { and location }\end{array}$ & $\begin{array}{l}\text { For construction permits fee, interconnection, } \\
\text { testing, and commissioning }\end{array}$ & NREL (2018) \\
\hline \multirow{3}{*}{$\begin{array}{l}\text { Transmission } \\
\text { line } \\
\text { (gen-tie line) }\end{array}$} & \multirow{3}{*}{$\begin{array}{l}\$ 0.00-\$ 0.02 / \mathrm{Wdc} \\
\text { Varies by system size }\end{array}$} & $\begin{array}{l}\text { System size }<10 \mathrm{MW} \text {; use } 0 \text { miles for gen- } \\
\text { tie line }\end{array}$ & \multirow{3}{*}{$\begin{array}{l}\text { Model assumptions, NREL } \\
(2018)\end{array}$} \\
\hline & & $\begin{array}{l}\text { System size > } 200 \text { MW; use } 5 \text { miles for gen- } \\
\text { tie line }\end{array}$ & \\
\hline & & $\begin{array}{l}\text { System size = 10-200 MW; use linear } \\
\text { interpolation }\end{array}$ & \\
\hline $\begin{array}{l}\text { Developer } \\
\text { overhead }\end{array}$ & $\begin{array}{l}2 \%-12 \% \\
\text { Varies by system size } \\
(100 \text { MW uses } 2 \% ; 5 \\
\text { MW uses } 12 \%)\end{array}$ & $\begin{array}{l}\text { Includes overhead expenses such as payroll, } \\
\text { facilities, travel, legal fees, administrative, } \\
\text { business development, finance, and other } \\
\text { corporate functions }\end{array}$ & $\begin{array}{l}\text { Model assumptions, NREL } \\
(2018)\end{array}$ \\
\hline Contingency & $3 \%$ & Estimated as markup on EPC cost & NREL (2018) \\
\hline Profit & $\begin{array}{l}5 \%-8 \% \\
\text { Varies by system size } \\
\text { (100 MW uses } 5 \% ; 5 \\
\text { MW uses } 8 \% \text { ) }\end{array}$ & $\begin{array}{l}\text { Applies a percentage margin to all costs } \\
\text { including hardware, installation labor, EPC } \\
\text { overhead, developer overhead, etc. }\end{array}$ & NREL (2018) \\
\hline
\end{tabular}


This year we updated our utility-scale model from 1,000 Vdc to 1,500 Vdc. A higher voltage means that we can add more modules per string to reduce trenching, wiring, and cabling work and reduce the number of combiner boxes. Table 7 shows the different characteristics for 1,000 Vdc versus $1,500 \mathrm{Vdc}$.

Table 7. Characteristics of Assuming 1,500 Vdc vs. 1,000 Vdc for Utility-Scale PV Systems

\begin{tabular}{|c|c|c|}
\hline & $1,000 \mathrm{Vdc}$ & $1,500 \mathrm{Vdc}$ \\
\hline Input max. voltage (Vdc) & 1,000 & 1,500 \\
\hline $\begin{array}{l}\text { Output nominal AC power } \\
\text { (MVA, megavolt amp) }\end{array}$ & 0.792 & 4 \\
\hline Rated AC operating voltage (Vac) & 356 & 550 \\
\hline Reduce trenching & $0 \%$ & $33 \%$ \\
\hline Reduce wiring and cables & $0 \%$ & $33 \%$ \\
\hline Reduce number of combiner boxes & $0 \%$ & $33 \%$ \\
\hline Power harvesting and system efficiency & Regular & Higher \\
\hline
\end{tabular}

Figure 25 shows the percentage of U.S. utility-scale PV systems using tracking systems for 2007-2017. Although the data include one-axis and dual-axis tracking systems in the same "tracking" category, there are many more one-axis trackers than dual-axis trackers (Bolinger and Seel 2018). Cumulative tracking system installation reached 79\% in 2017. 


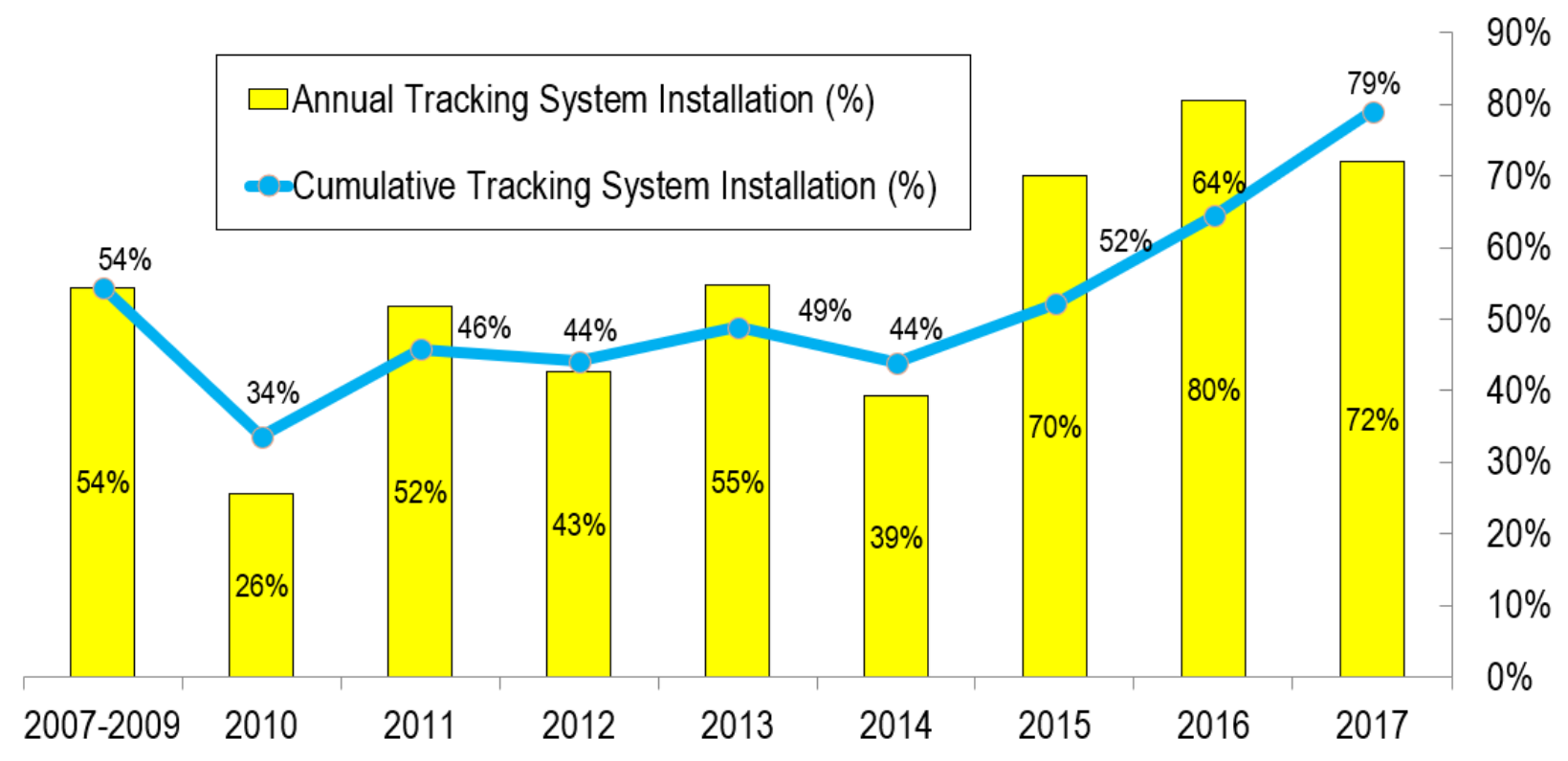

Figure 25. Percentage of U.S. utility-scale PV systems using tracking systems, 2007-2017 (Bolinger and Seel 2018)

Although EPC contractors and developers tend to employ low-cost, non-union labor (based on data from BLS 2018) for PV system construction when possible, union labor is sometimes mandated. Construction trade unions may negotiate with the local jurisdiction and EPC contractor/developer during the public review period of the permitting process. Figure 26 shows 2017 utility-scale PV capacity installed (GTM Research and SEIA 2018) and the proportion of unionized labor in each state (BLS 2018). The unionized labor number represents the percentage of employed workers in each state's entire construction industry who are union members. In our utility-scale model, both non-union and union labor rates are considered (Figure 27). 


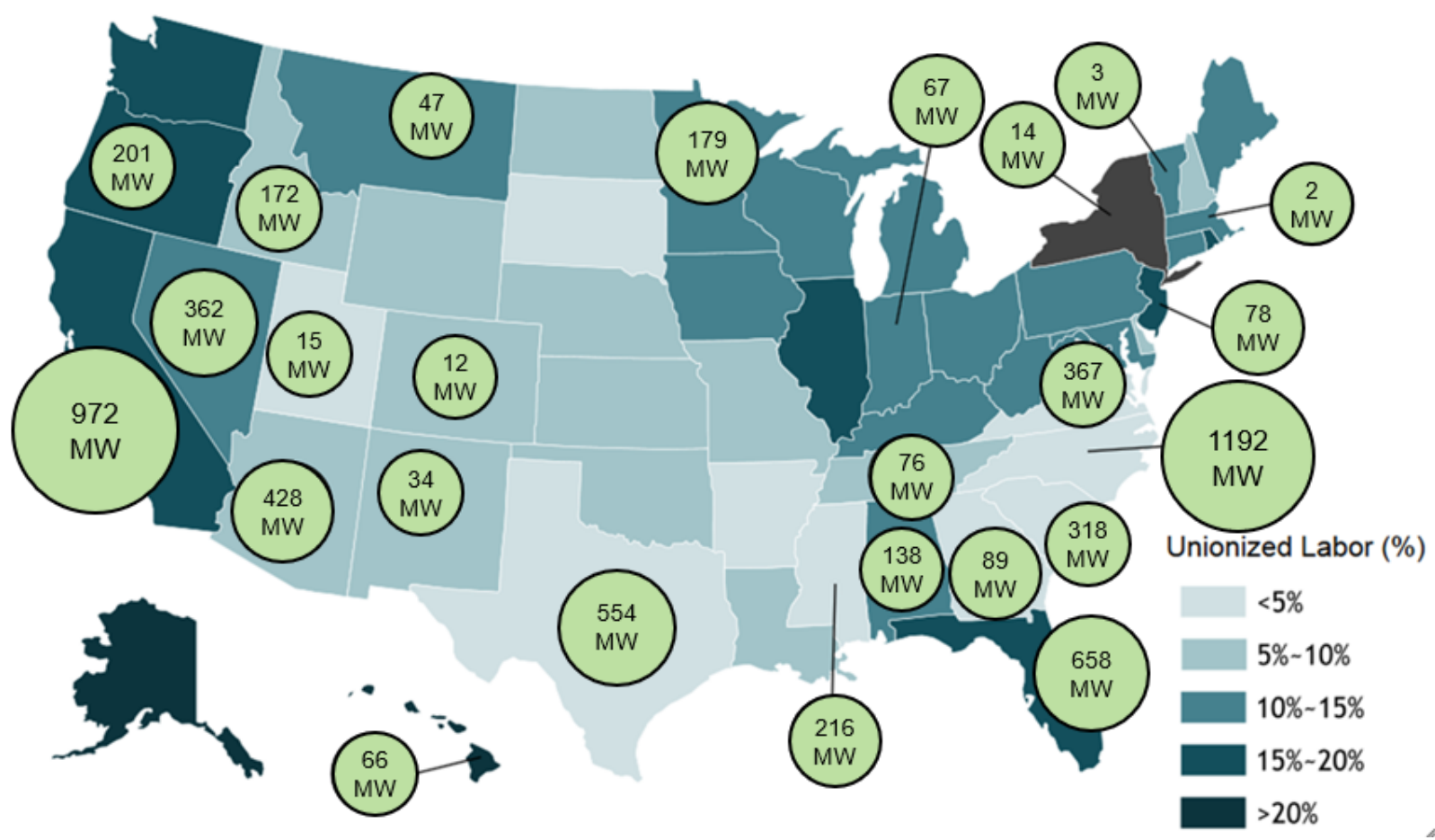

Figure 26. Utility-scale PV: 2017 capacity installed and percentage of unionized labor by state (BLS 2018, GTM Research and SEIA 2018)

\subsection{Utility-Scale Model Output}

Figure 27 presents the regional EPC benchmark from our utility-scale model, and Figure 28 presents the U.S. national benchmark (EPC + developer) for fixed-tilt and one-axis tracker systems, using non-union labor. In Figure 28, note the following:

1. The national benchmark applies an average weighted by 2017 installed capacities.

2. Non-union labor is used.

3. Economies of scale — driven by BOS, labor, related markups, and development cost —are demonstrated. 


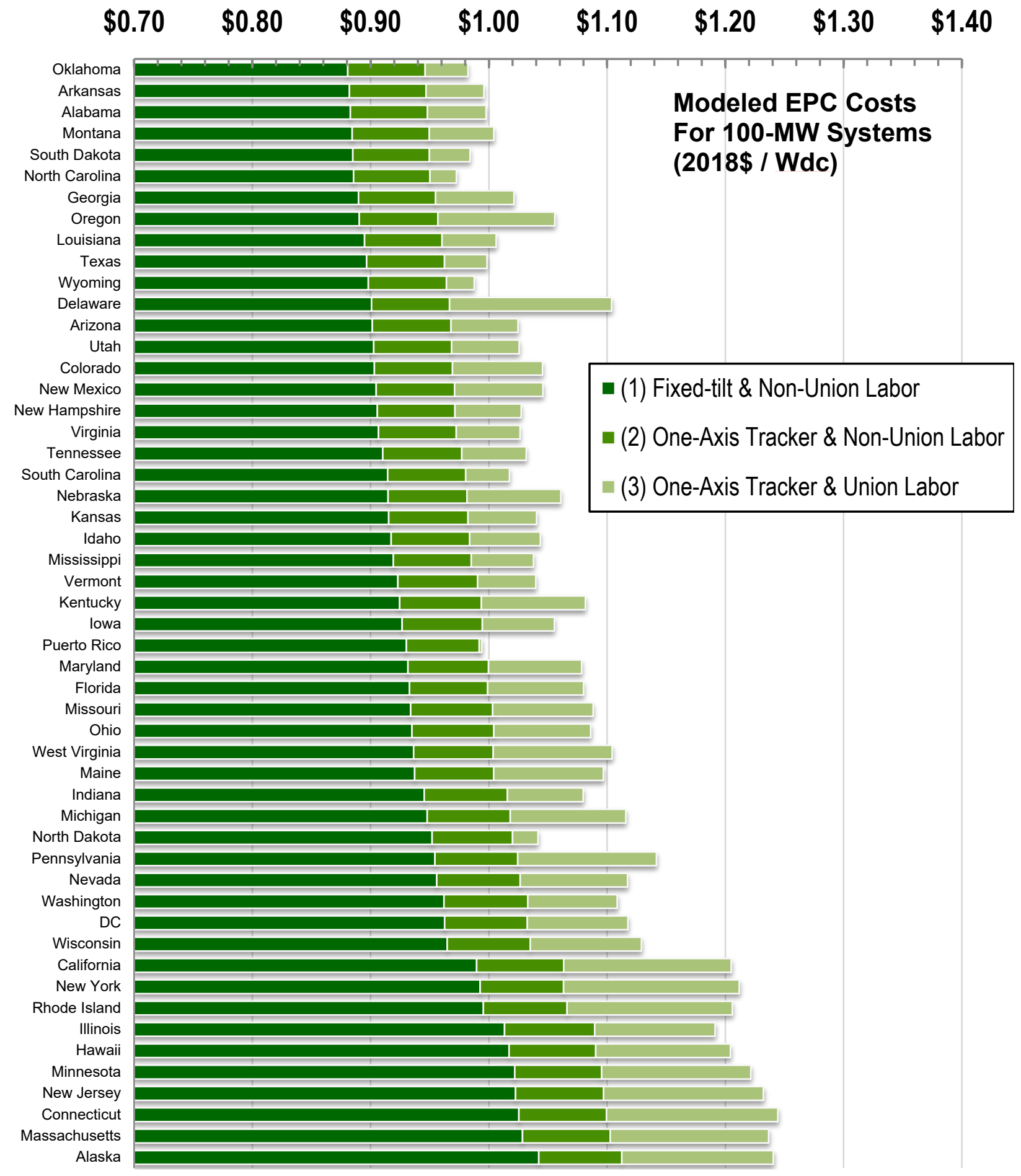

Figure 27. Q1 2018 benchmark by location: 100-MW utility-scale PV systems, EPC only (2018 USD/Wdc) ${ }^{21}$

\footnotetext{
${ }^{21}$ The fixed-tilt, non-union cost is always lowest, followed by the one-axis tracker, non-union cost and the one-axis tracker, union cost. Thus, the bars are additive: the fixed-tilt, non-union cost is represented by the dark green bar
} 


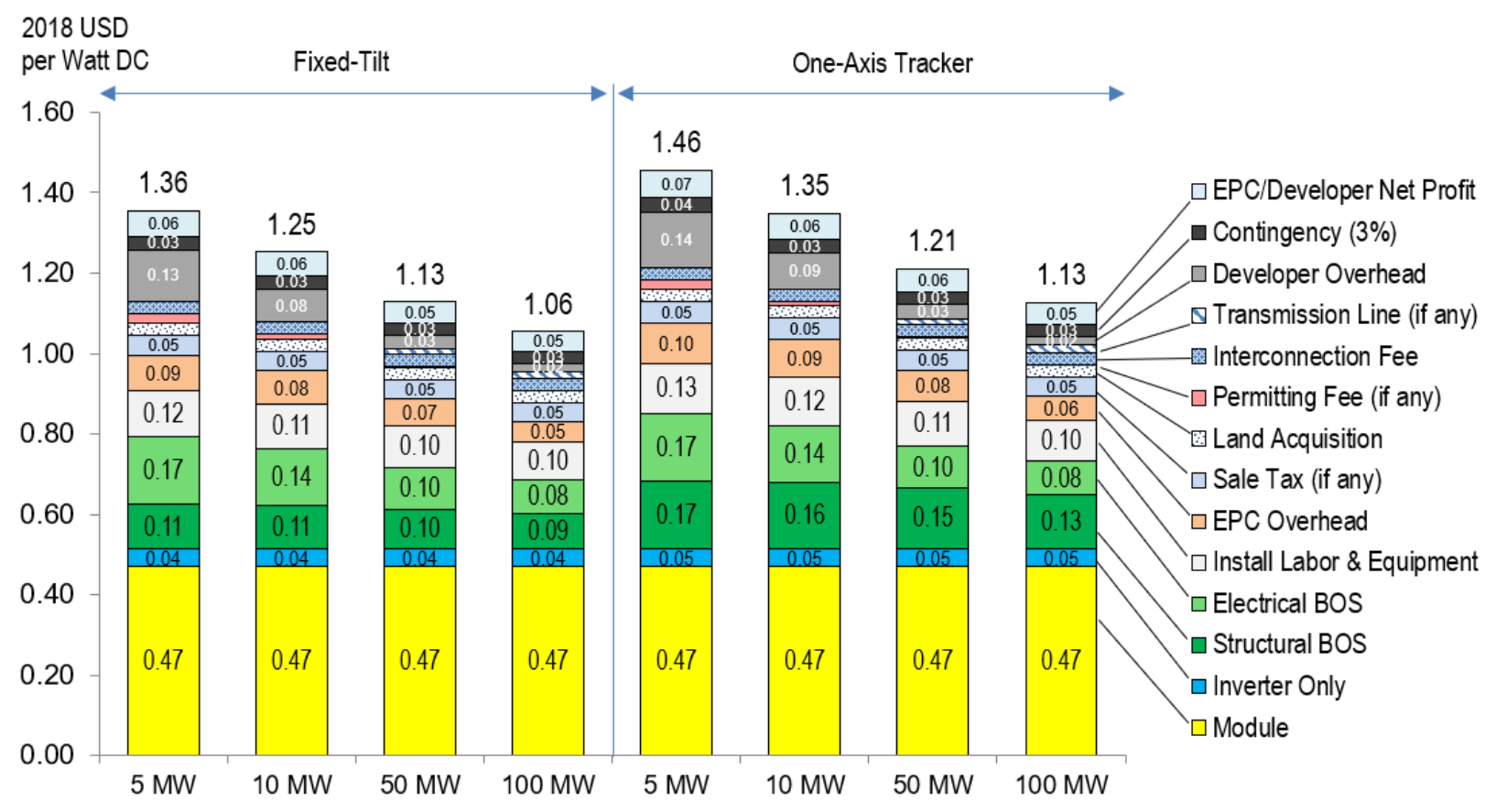

Figure 28. Q1 2018 U.S. benchmark: utility-scale PV total cost (EPC + developer), 2018 USD/Wdc

\subsection{Utility-Scale PV Price Benchmark Historical Trends}

Figure 29 shows the $77 \%$ (fixed-tilt) and $80 \%$ (one-axis tracking) reductions in utility-scale PV system cost benchmarks between 2010 and $2018 .{ }^{22}$ Approximately $69 \%$ (fixed) and $63 \%$ (oneaxis) of those reductions can be attributed to total hardware costs, with module prices dropping $81 \%$ over that period. An additional $11 \%$ (fixed) and $12 \%$ (one-axis) can be attributed to labor, which dropped $81 \%$ (fixed) and $84 \%$ (one-axis) over that period. The final $20 \%$ (fixed) and $25 \%$ (one-axis) are attributable to other soft costs, including PII, sales tax, overhead, and net profit.

alone; the one-axis tracker, non-union cost is the sum of the dark green and medium green bars; and the one-axis tracker, union cost is the sum of all three bars.

22 Each year's PV system cost benchmark corresponds to the NREL benchmark calculted in Q4 of the previous year or Q1 of the current year (e.g., 2010=Q4 2009; $2017=$ Q1 2017). 


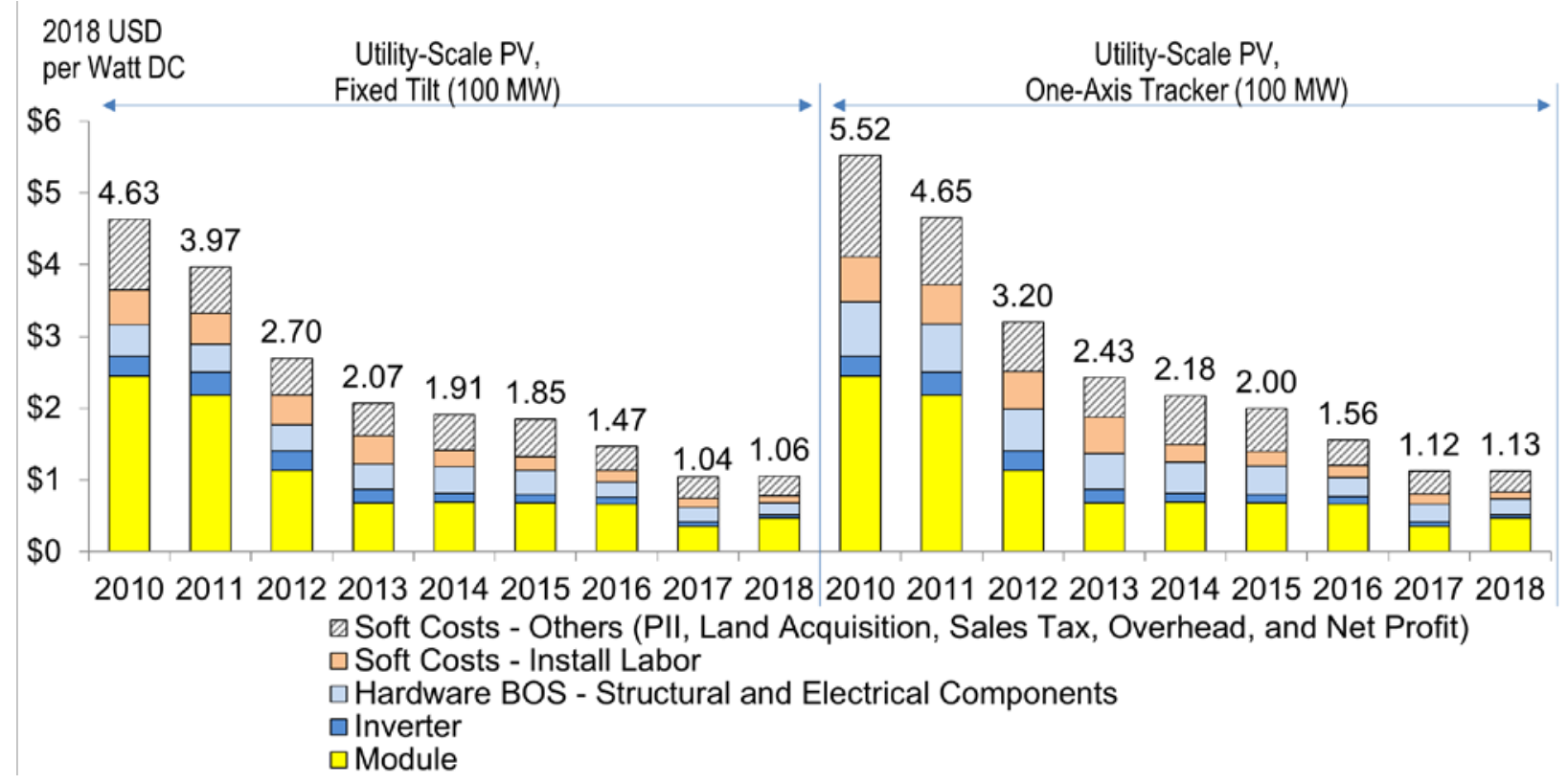

Figure 29. NREL utility-scale PV system cost benchmark summary (inflation adjusted), 2010-2018

From 2017 to 2018, there was a 1\% increase in the utility-scale (fixed-tilt) PV system cost benchmark, and a $0.4 \%$ increase in the utility-scale (one-axis) PV system cost benchmark. The majority of that increase can be attributed to the $32 \%$ increase in module spot price, which offset cost reductions in other areas.

\subsection{Utility-Scale PV Levelized Cost of Energy Historical Trends}

Assumptions for the utility-scale PV LCOE benchmarks from 2010 to 2018 are summarized in Table 8 . In addition to an $80 \%$ reduction in the installed cost of utility-scale (one-axis) systems from 2010 to 2018, O\&M costs declined 49\%, annual degradation declined 30\%, equity discount rate declined $14 \%$, debt interest rate declined $18 \%$, and debt fraction increased $17 \%$.

Using these assumptions, we calculate the utility-scale PV LCOE-with and without the 30\% federal ITC - in Phoenix (high solar resource), Kansas City (medium), and New York City (low), corresponding to the locations used to calculate LCOE in the SunShot Vision Study (U.S. DOE 2012) (Figure 30). ${ }^{23}$ We use the fixed-tilt systems for LCOE benchmarks from 2010 to 2015 and then switch to one-axis tracking systems from 2016 to 2018 to reflect the market share change in Figure 25. All detailed LCOE values can be found in the appendix.

From 2010 to 2018, utility-scale PV LCOE declined 80\%-82\% (6\%-9\% between 2017 and $2018)$, resulting in an unsubsidized LCOE of $\$ 0.04-\$ 0.06 / \mathrm{kWh}(\$ 0.03-\$ 0.04 / \mathrm{kWh}$ when including the federal ITC). This reduction signifies the achievement of SETO's 2020 utility-scale PV goal. ${ }^{24}$

\footnotetext{
${ }^{23}$ Because this analysis uses a more robust set of current and historical assumptions, LCOE values may differ from previously reported benchmarked values.

${ }^{24}$ The 2020 utility-scale goal is not adjusted for inflation, because wholesale electricity prices were relatively flat, and in some cases declined, from 2010-2018. A summary of these values can be found in Appendix A.
} 
Table 8. One-Axis Tracker and Fixed-Tilt Utility-Scale PV LCOE Assumptions, 2010-2018

\begin{tabular}{|c|c|c|c|c|c|c|c|c|c|}
\hline 2018 USD per Watt DC & 2010 & 2011 & 2012 & 2013 & 2014 & 2015 & 2016 & 2017 & 2018 \\
\hline \multicolumn{10}{|l|}{ One-Axis Tracker } \\
\hline Installed cost $(\$ / \mathrm{W})$ & 5.52 & 4.65 & 3.20 & 2.43 & 2.18 & 2.00 & 1.56 & 1.12 & 1.13 \\
\hline Annual degradation (\%) & $1.00 \%$ & $0.95 \%$ & $0.90 \%$ & $0.85 \%$ & $0.80 \%$ & $0.75 \%$ & $0.75 \%$ & $0.75 \%$ & $0.70 \%$ \\
\hline O\&M expenses (\$/kW-yr) & 28 & 27 & 25 & 24 & 23 & 22 & 21 & 20 & 14 \\
\hline Pre-inverter derate (\%) & $90.5 \%$ & $90.5 \%$ & $90.5 \%$ & $90.5 \%$ & $90.5 \%$ & $90.5 \%$ & $90.5 \%$ & $90.5 \%$ & $90.5 \%$ \\
\hline Inverter efficiency (\%) & $96.0 \%$ & $96.4 \%$ & $96.8 \%$ & $97.2 \%$ & $97.6 \%$ & $98.0 \%$ & $98.0 \%$ & $98.0 \%$ & $98.0 \%$ \\
\hline Inverter loading ratio & 1.10 & 1.12 & 1.13 & 1.15 & 1.17 & 1.18 & 1.20 & 1.30 & 1.30 \\
\hline Equity discount rate (real) & $7.4 \%$ & $7.2 \%$ & $7.0 \%$ & $6.9 \%$ & $6.7 \%$ & $6.5 \%$ & $6.3 \%$ & $6.3 \%$ & $6.3 \%$ \\
\hline Inflation rate & $2.5 \%$ & $2.5 \%$ & $2.5 \%$ & $2.5 \%$ & $2.5 \%$ & $2.5 \%$ & $2.5 \%$ & $2.5 \%$ & $2.5 \%$ \\
\hline Debt interest rate & $5.5 \%$ & $5.3 \%$ & $5.2 \%$ & $5.0 \%$ & $4.8 \%$ & $4.7 \%$ & $4.5 \%$ & $4.5 \%$ & $4.5 \%$ \\
\hline Debt fraction & $34.2 \%$ & $35.2 \%$ & $36.1 \%$ & $37.1 \%$ & $38.1 \%$ & $39.0 \%$ & $40.0 \%$ & $40.0 \%$ & $40.0 \%$ \\
\hline \multicolumn{10}{|l|}{ Fixed-Tilt } \\
\hline Installed cost $(\$ / W)$ & 4.63 & 3.97 & 2.70 & 2.07 & 1.91 & 1.85 & 1.47 & 1.04 & 1.06 \\
\hline Annual degradation (\%) & $1.00 \%$ & $0.95 \%$ & $0.90 \%$ & $0.85 \%$ & $0.80 \%$ & $0.75 \%$ & $0.75 \%$ & $0.75 \%$ & $0.70 \%$ \\
\hline O\&M expenses (\$/kW-yr) & 28 & 26 & 24 & 22 & 20 & 18 & 18 & 17 & 13 \\
\hline Pre-inverter derate (\%) & $90.5 \%$ & $90.5 \%$ & $90.5 \%$ & $90.5 \%$ & $90.5 \%$ & $90.5 \%$ & $90.5 \%$ & $90.5 \%$ & $90.5 \%$ \\
\hline Inverter efficiency (\%) & $96.0 \%$ & $96.4 \%$ & $96.8 \%$ & $97.2 \%$ & $97.6 \%$ & $98.0 \%$ & $98.0 \%$ & $98.0 \%$ & $98.0 \%$ \\
\hline Inverter loading ratio & 1.10 & 1.15 & 1.20 & 1.25 & 1.30 & 1.35 & 1.40 & 1.30 & 1.36 \\
\hline Equity discount rate (real) & $7.4 \%$ & $7.2 \%$ & $7.0 \%$ & $6.9 \%$ & $6.7 \%$ & $6.5 \%$ & $6.3 \%$ & $6.3 \%$ & $6.3 \%$ \\
\hline Inflation rate & $2.5 \%$ & $2.5 \%$ & $2.5 \%$ & $2.5 \%$ & $2.5 \%$ & $2.5 \%$ & $2.5 \%$ & $2.5 \%$ & $2.5 \%$ \\
\hline Debt interest rate & $5.5 \%$ & $5.3 \%$ & $5.2 \%$ & $5.0 \%$ & $4.8 \%$ & $4.7 \%$ & $4.5 \%$ & $4.5 \%$ & $4.5 \%$ \\
\hline Debt fraction & $34.2 \%$ & $35.2 \%$ & $36.1 \%$ & $37.1 \%$ & $38.1 \%$ & $39.0 \%$ & $40.0 \%$ & $40.0 \%$ & $40.0 \%$ \\
\hline
\end{tabular}

All 2010-2017 data are from Fu et al. (2017), adjusted for inflation. The inverter replacement line-item in Fu et al. (2017) is incorporated into O\&M expenses in this edition to be consistent with the 2018 O\&M benchmark. Other important assumptions: utility-scale PV system LCOEs assume a 1) system lifetime of 30 years; 2) federal tax rate of $35 \%$ from 2010-2017, changing to $21 \%$ in 2018; 3) state tax rate of $7 \%$; 4) MACRS depreciation schedule; 5) no state or local subsidies; 6 ) a working capital and debt service reserve account for 6 months of operating costs and debt payments (earning interest of $1.75 \%$ ); 7 ) a 6 -month construction loan with an interest rate of $4 \%$ and a fee of $1 \%$ of the cost of the system; 8) a system size of $100 \mathrm{MW}$; 9) an inverter lifetime of 15 years; 10) debt with a term of 18 years; and 11) \$1.1 million of upfront financial transaction costs. 


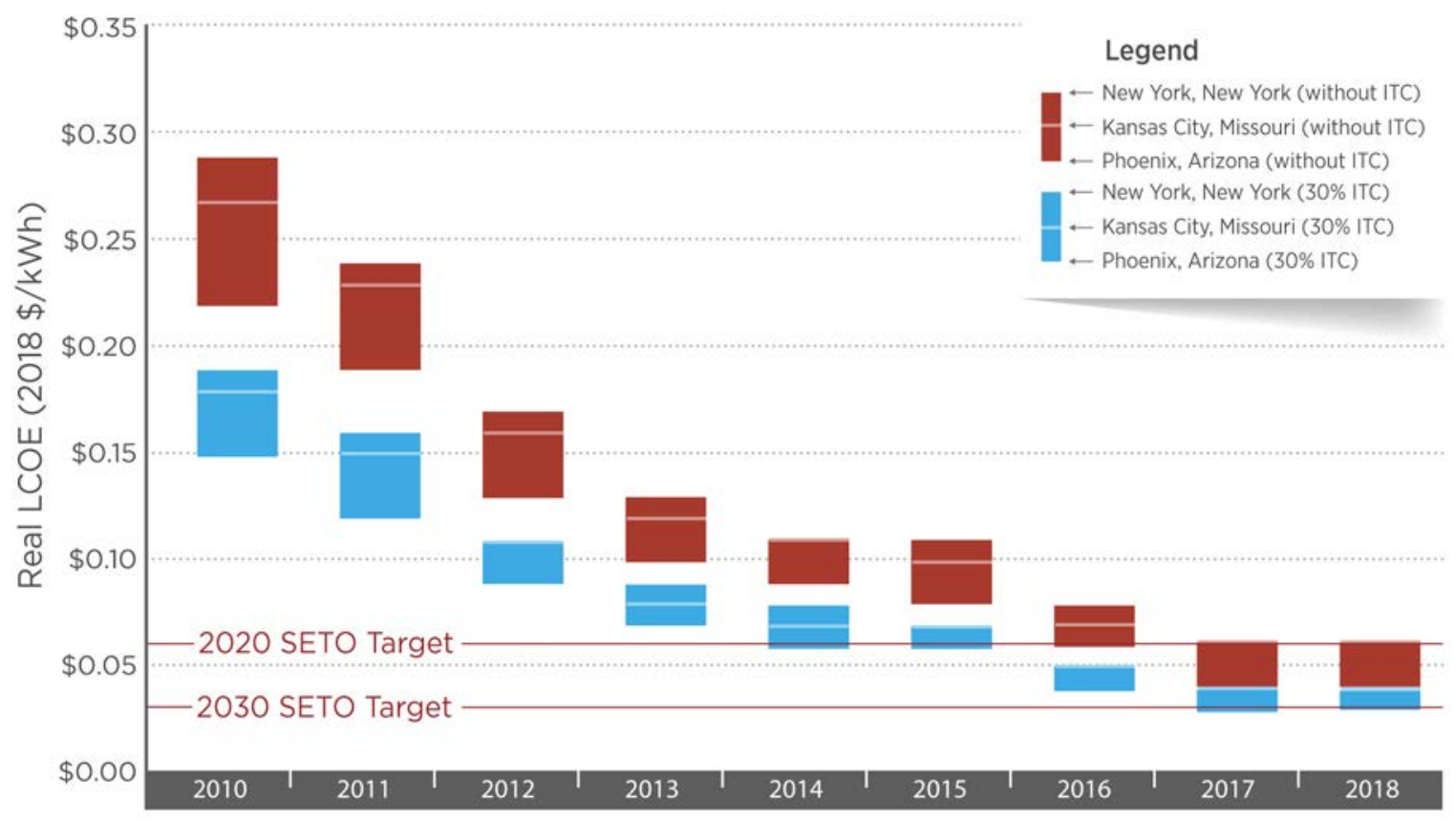

Figure 30. LCOE for utility-scale PV systems, by region, with and without ITC, 2010-2018 


\section{Model Applications}

This section includes two additional applications of our cost modeling: system cost reduction from economies of scale (Section 6.1) and module efficiency impacts (Section 6.2). The granularity of our bottom-up models enables us to determine the changes in particular cost drivers over time. Accordingly, the models can be used to predict future system cost-reduction opportunities based on particular market trends and technologies.

\subsection{System Cost Reduction from Economies of Scale}

Figure 31 demonstrates the cost savings from increased system size. Scaling up the system size from $50 \mathrm{MW}$ to $100 \mathrm{MW}$ reduces related costs in several ways: per-watt BOS costs are reduced because of bulk purchasing, labor costs benefit from learning-related improvements for larger systems, and EPC overhead and developer costs are spread over more installed capacity. Note that non-union labor is used in this figure.

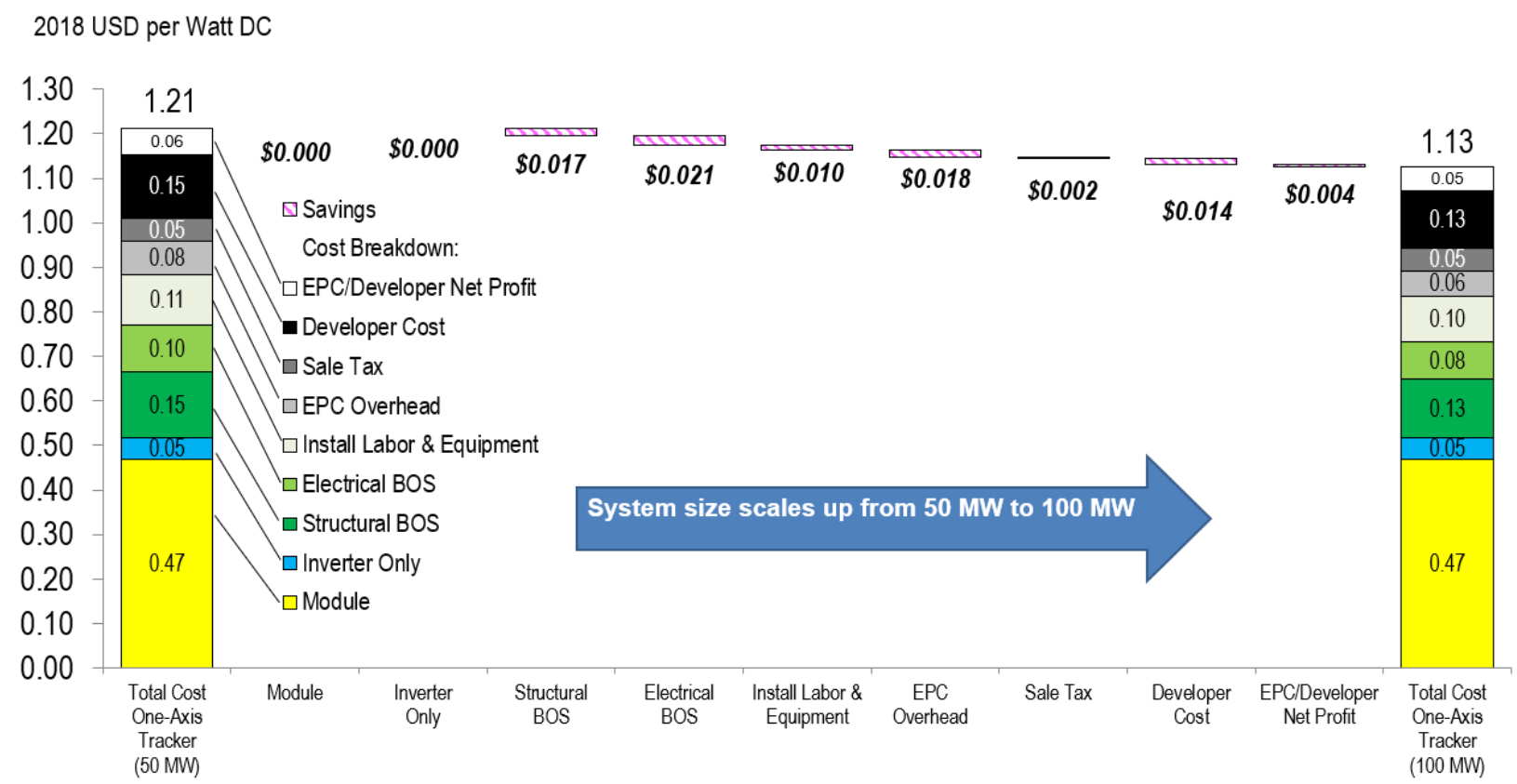

Figure 31. Model application: U.S. utility-scale one-axis tracking PV system cost reduction from economies of scale (2018 USD/Wdc)

\subsection{Module Efficiency Impacts}

Our system cost models can also assess the economic benefits of high module efficiency. Because higher module efficiency reduces the number of modules required to reach a certain system size, the related racking or mounting hardware, foundation, BOS, EPC/developer overhead, and labor hours are reduced accordingly. Figure 32 presents the relationship between module efficiency and installed cost (with module prices held equal for any given efficiency) and demonstrates the cost-reduction potential due to high module efficiency. Note that a fixed-tilt system is used in the utility-scale curve and a string inverter is used in the residential curve. 
2018 USD

per Watt DC
$\$ 3.50] 2018$ Residential in CA (string inverter):
$\$ 3.00$

Residential in CA:

$5 \%$ module efficiency means

$\mathrm{kW}$ and $\$ 2.33 / \mathrm{W}$

Future Commercial in CA: $\neg-$ Residential Installed Cost (Fixed System Area=39 sqr meter, Changeable System Size)

$\sim$ Commercial Installed Cost (Fixed System Area=0.6 Acre, Changeable System Size)

- - Utility-Scale Installed Cost (Fixed System Area=580 Acre, Changeable System Size)

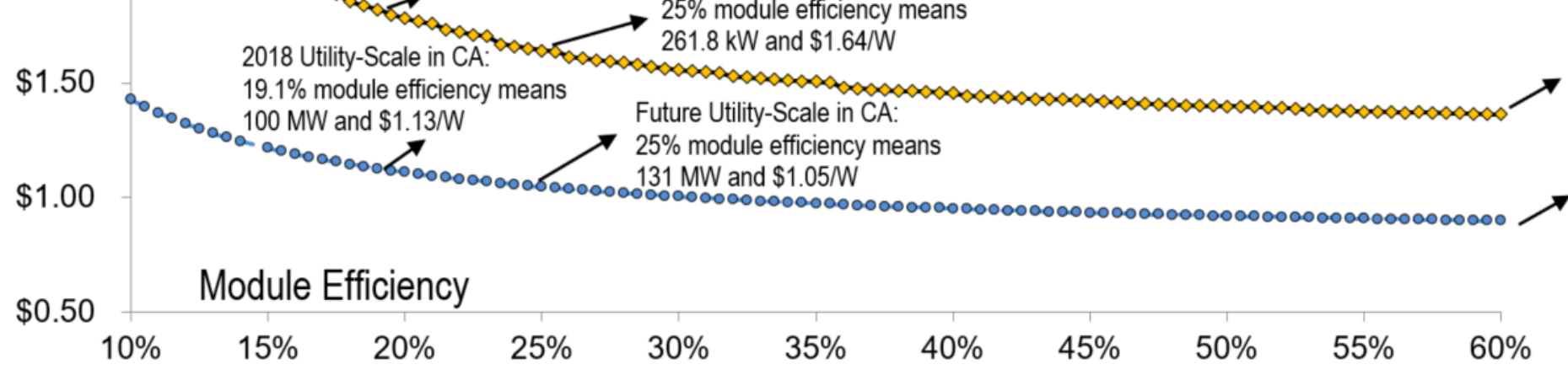

Future Residential in CA: including crystalline silicon, but it is possible for multi-junction cells.

$\boldsymbol{\nabla} 60 \%$ module efficiency means

$22 \mathrm{~kW}$ and $\$ 1.99 / \mathrm{W}$

Future Commercial in CA:

$60 \%$ module efficiency means

$628 \mathrm{~kW}$ and $\$ 1.36 / \mathrm{W}$

Future Utility-Scale in CA:

$60 \%$ module efficiency means $314 \mathrm{MW}$ for $\$ 0.90 \mathrm{~W}$

Figure 32. Modeled impacts of module efficiency on total system costs, 2018 


\section{Conclusions}

Based on our bottom-up modeling, the Q1 2018 PV cost benchmarks are $\$ 2.70 / \mathrm{Wdc}$ $(\$ 3.11 / \mathrm{Wac})$ for residential systems, $\$ 1.83 / \mathrm{Wdc}(\$ 2.10 / \mathrm{Wac})$ for commercial systems, $\$ 1.06 / \mathrm{Wdc}(\$ 1.44 / \mathrm{Wac})$ for fixed-tilt utility-scale systems, and $\$ 1.13 / \mathrm{Wdc}(\$ 1.47 / \mathrm{Wac})$ for one-axis-tracking utility-scale systems. Overall, modeled installed costs of residential and commercial PV systems continued to decline in Q1 2018. Meanwhile, modeled utility-scale PV system cost increased slightly.

Figure 33 puts our Q1 2018 benchmark results in context with the results of previous NREL benchmarking analyses. When comparing the results across this period, note the following:

1. Values are inflation adjusted using the U.S. Bureau of Labor Statistics' Consumer Price Index. Thus, historical values from our models are adjusted and presented as real USD instead of as nominal USD.

2. Cost categories are aggregated for comparison purposes. "Soft Costs - Others" represents PII, land acquisition, sales tax, and EPC/developer overhead and profit.

3. The "Utility-Scale PV, One-Axis Tracker (100 MW)" consists of our previous bottom-up results (2010 and 2013-2016) and interpolation estimates for 2009 and 2011-2012.

4. The comparison of Q1 2017 and Q1 2018 is presented in Table 9.

The inflation-adjusted system cost differences between Q1 2017 and Q1 2018 are a \$0.14/Wdc decrease for residential PV, a $\$ 0.05 / \mathrm{Wdc}$ decrease for commercial $\mathrm{PV}$, a $\$ 0.02 / \mathrm{Wdc}$ increase for fixed-tilt utility-scale PV, and a $\$ 0.01 / \mathrm{Wdc}$ increase for one-axis tracker utility-scale PV. Table 9 shows the benchmarked values for all three sectors and drivers of cost decreases and increases.

As Figure 33 shows, hardware cost did not decline substantially in Q1 2018 owing to module price increases. This has decreased the percentage of non-hardware, or "soft," costs. ${ }^{25}$ Figure 34 shows the various contributions from soft costs. ${ }^{26}$ Soft costs and hardware costs also interact with each other. For instance, module efficiency improvements have reduced the number of modules required to construct a system of a given size, thus reducing hardware costs.

Also, our bottom-up system cost models enable us to investigate regional variations, system configurations (such as MLPE vs. non-MLPE, fixed-tilt vs. one-axis tracker, and small vs. large system size). In addition, business structures (such as installer vs. integrator, and EPC vs. developer) are considered. Different scenarios result in different costs, so consistent comparisons can only be made when cost scenarios are aligned.

Finally, the reduction in installed cost—along with improvements in operation, system design, and technology - have resulted in significant LCOE reductions (Figure 35). U.S. residential and commercial PV systems are 89\% and 91\% toward achieving SETO's 2020 electricity price targets, and U.S. utility-scale PV systems have achieved their 2020 SETO target 3 years early.

\footnotetext{
${ }^{25}$ Soft cost $=$ total cost - hardware (module, inverter, structural, and electrical BOS) cost.

${ }^{26}$ An increasing soft cost proportion in Figure 34 indicates soft costs declined more slowly than did hardware costs; it does not indicate soft costs increased on an absolute basis.
} 


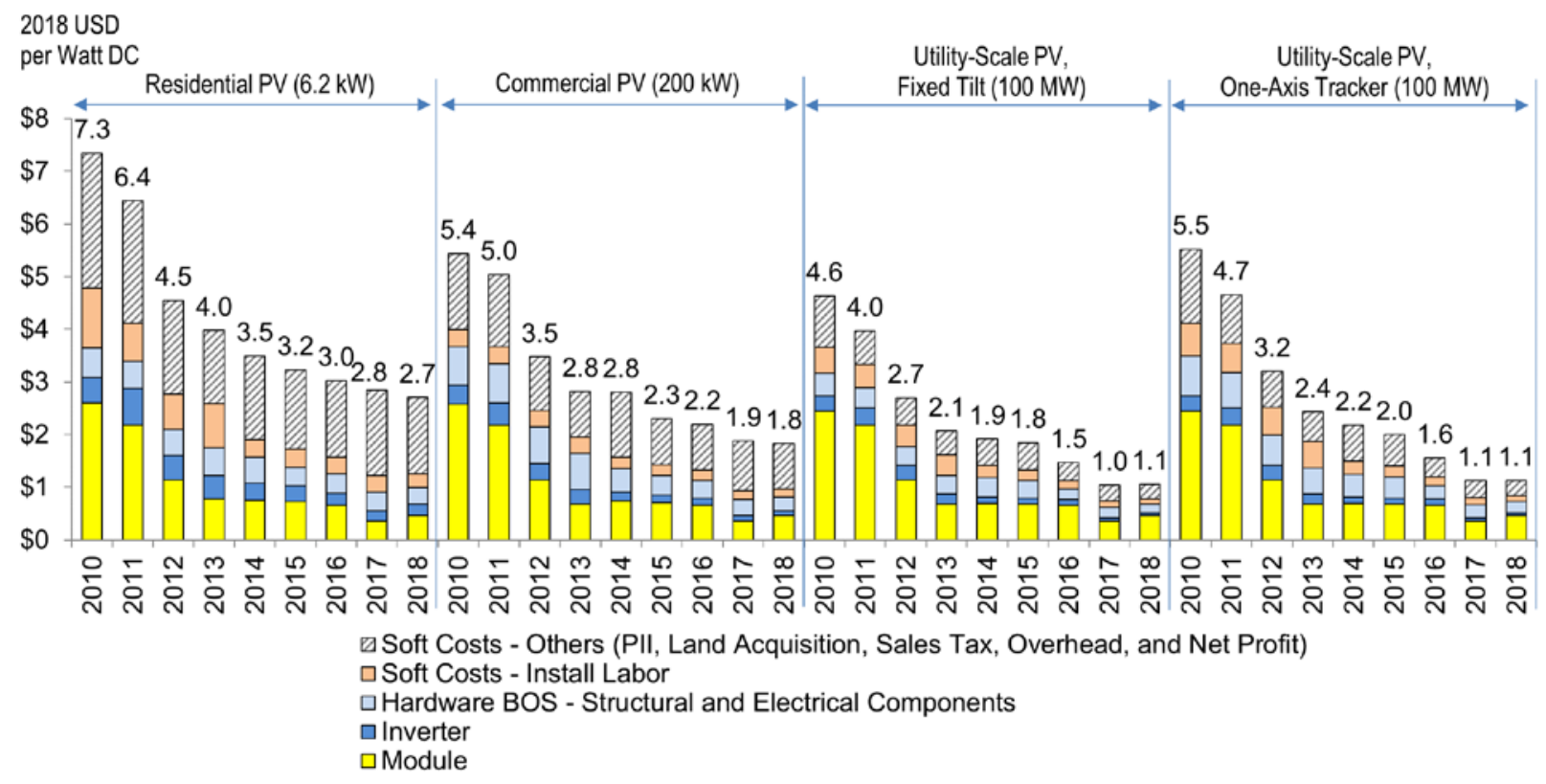

Figure 33. NREL PV system cost benchmark summary (inflation adjusted), 2010-2018 
Table 9. Comparison of Q1 2017 and Q1 2018 PV System Cost Benchmarks

\begin{tabular}{|c|c|c|c|}
\hline Sector & Residential PV & Commercial PV & $\begin{array}{l}\text { Utility-Scale PV, One- } \\
\text { Axis Tracking }\end{array}$ \\
\hline $\begin{array}{l}\text { Q1 } 2017 \\
\text { Benchmarks in } \\
2017 \text { USD/Wdc }\end{array}$ & $\$ 2.80$ & $\$ 1.85$ & $\$ 1.11$ \\
\hline $\begin{array}{l}\text { Q1 } 2017 \\
\text { Benchmarks in } \\
2018 \text { USD/Wdc }\end{array}$ & $\$ 2.84$ & $\$ 1.88$ & $\$ 1.12$ \\
\hline $\begin{array}{l}\text { Q1 } 2018 \\
\text { Benchmarks in } \\
2018 \text { USD/Wdc }\end{array}$ & $\$ 2.70$ & $\$ 1.83$ & $\$ 1.13$ \\
\hline $\begin{array}{l}\text { Drivers of Cost } \\
\text { Decrease }\end{array}$ & $\begin{array}{ll}\text { - } & \text { Higher module } \\
\text { efficiency } \\
\text { - } & \text { Lower structural BOS } \\
\text { commodity price } \\
\text { - } \quad \text { Lower electrical BOS } \\
\text { commodity price } \\
\text { - } \text { Higher labor } \\
\text { productivity } \\
\text { - } \quad \text { Lower supply chain } \\
\text { costs } \\
\text { - } \quad \text { Decrease in higher- } \\
\text { cost module inventory } \\
\text { - Higher small installer } \\
\text { - } \text { market share } \\
\text { Lower permitting cost }\end{array}$ & $\begin{array}{ll}\text { - } & \text { Lower inverter } \\
\text { price } \\
\text { - } & \text { Higher module } \\
\text { efficiency } \\
\text { - } \quad \text { Smaller } \\
\text { developer team } \\
\text { - Lower permitting } \\
\text { and } \\
\text { interconnection } \\
\text { costs }\end{array}$ & $\begin{array}{ll}\text { - } & \text { Lower inverter price } \\
\text { - } & \text { Higher module } \\
\text { efficiency } \\
\text { Optimized design } \\
\text { coefficients for wind } \\
\text { loads } \\
\text { - } 1,500 \mathrm{Vdc} \text { to replace } \\
1,000 \mathrm{Vdc} \\
\text { - } \quad \text { Lower developer } \\
\text { overhead }\end{array}$ \\
\hline $\begin{array}{l}\text { Drivers of Cost } \\
\text { Increase }\end{array}$ & $\begin{array}{l}\text { Higher mixed inverter } \\
\text { price due to higher } \\
\text { advanced inverter } \\
\text { adoption } \\
\text { - Higher module price } \\
\text { - Higher labor wages }\end{array}$ & $\begin{array}{l}\text { - Higher module } \\
\text { price } \\
\text { - Higher labor } \\
\text { wages }\end{array}$ & $\begin{array}{ll}\text { - } & \text { Higher module price } \\
\text { - } & \text { Higher labor wages } \\
& \text { Higher steel prices }\end{array}$ \\
\hline
\end{tabular}




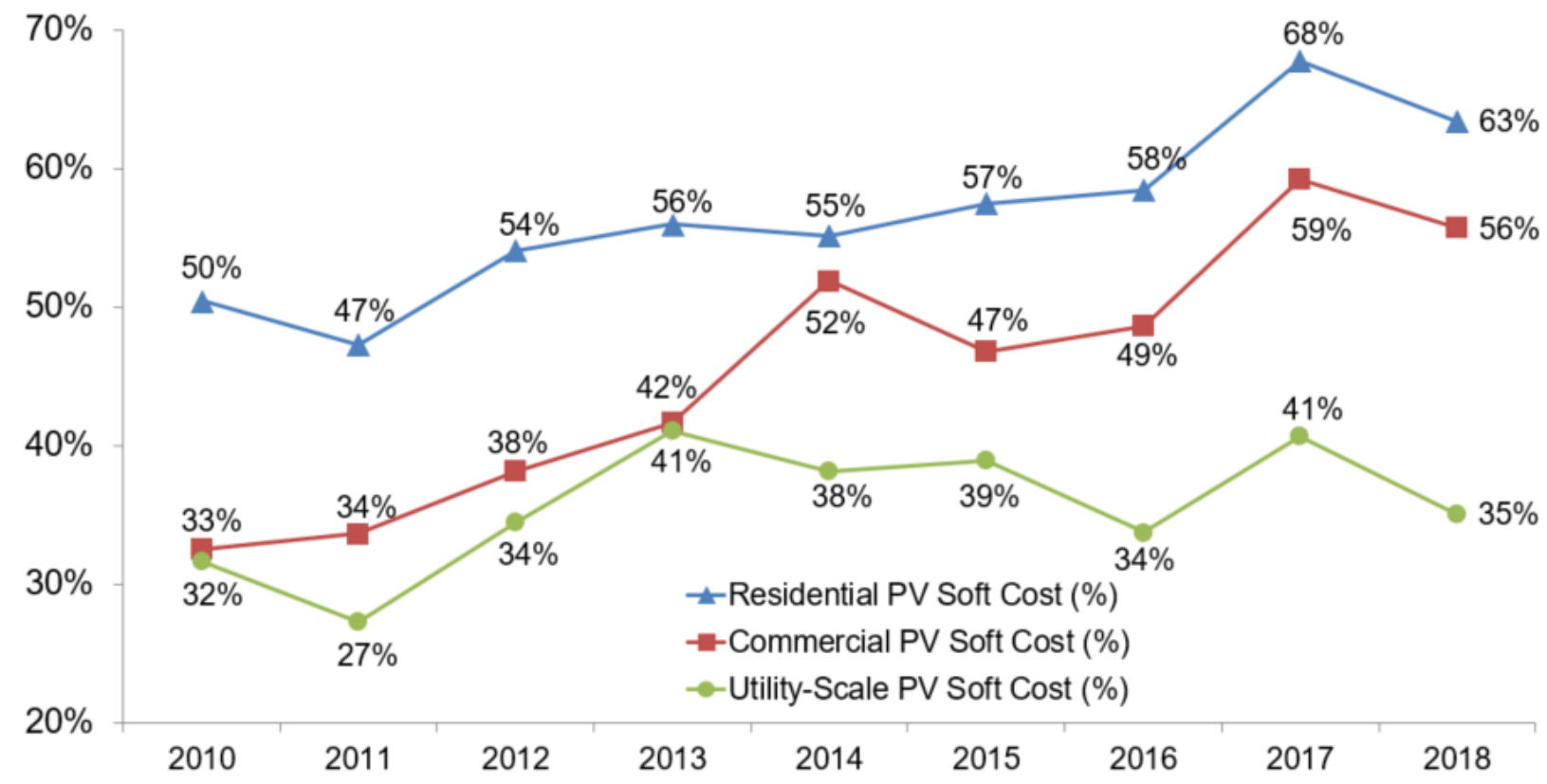

Figure 34. Modeled trend of soft cost as a proportion of total cost by sector, 2010-2018

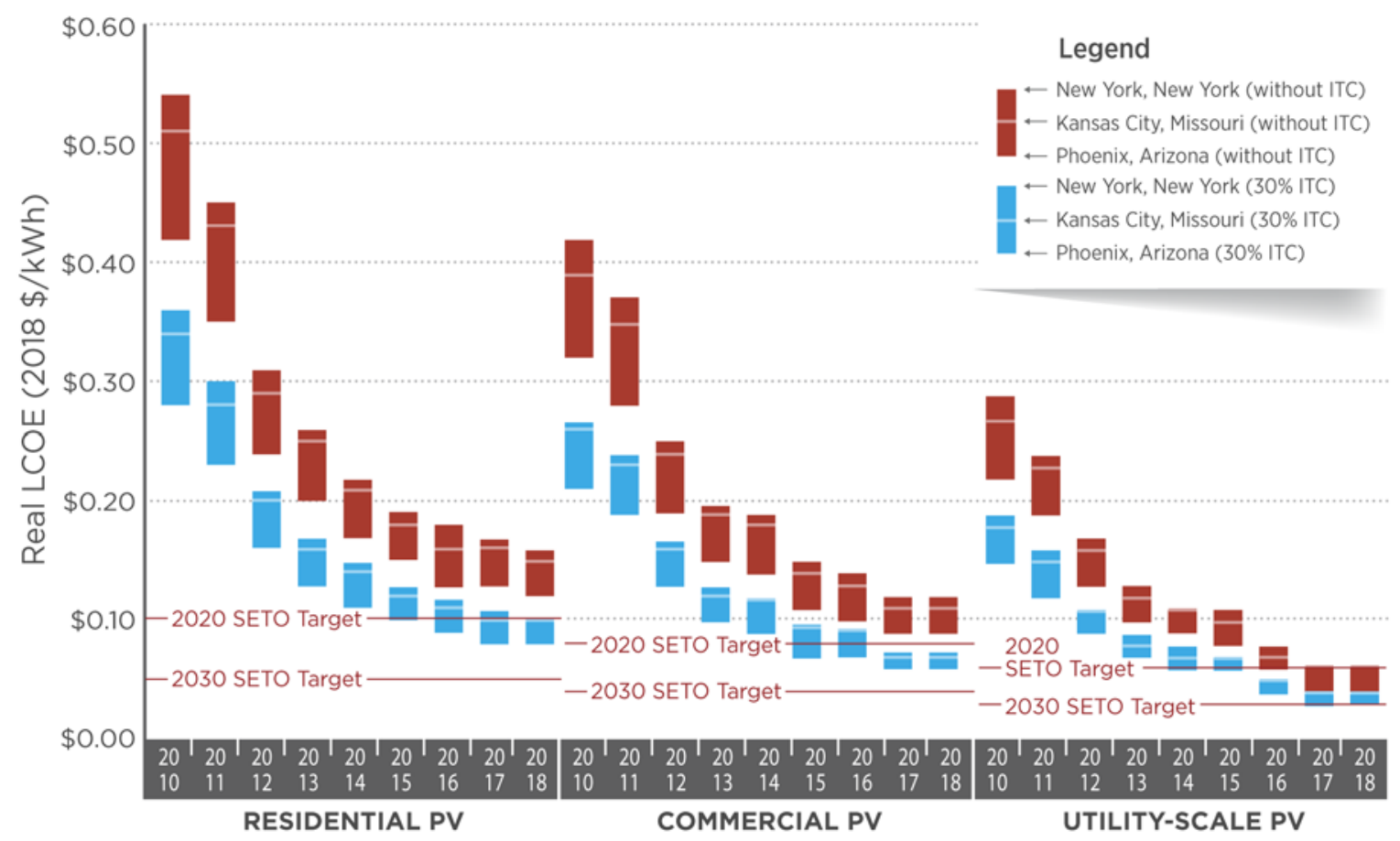

Figure 35. NREL PV LCOE benchmark summary (inflation adjusted), 2010-2018 


\section{References}

ASCE (American Society of Civil Engineers). 2006. Minimum Design Loads for Buildings and Other Structures (7-05). Reston, VA: American Society of Civil Engineers.

Barbose, G., and N. Darghouth. 2016. Tracking the Sun IX: The Installed Price of Residential and Non-Residential Photovoltaic Systems in the United States. Berkeley, CA: Lawrence Berkeley National Laboratory. https://emp.lbl.gov/publications/tracking-sun-ix-installed-price.

Bloomberg. 2018. Bloomberg Professional service. Accessed May 20, 2018.

BLS (U.S. Bureau of Labor Statistics). 2018. "Occupational Employment Statistics.” Accessed May 8, 2018. http://www.bls.gov/oes/tables.htm.

Bolinger, M., and J. Seel. 2018. Utility-Scale Solar 2017: An Empirical Analysis of Project Cost, Performance, and Pricing Trends in the United States. Berkeley, CA: Lawrence Berkeley National Laboratory.

Bolinger, M., and J. Seel. 2016. Utility-Scale Solar 2015: An Empirical Analysis of Project Cost, Performance, and Pricing Trends in the United States. Berkeley, CA: Lawrence Berkeley National Laboratory. https://emp.lbl.gov/publications/utility-scale-solar-2015-empirical.

Case, T. 2012. "US Cost of Doing Business: Costs Fall in 2010.” Moody's Analytics Regional Financial Review, September 2012.

Chung, D., C. Davidson, R. Fu, K. Ardani, and R. Margolis. 2015. U.S. Photovoltaic Prices and Cost Breakdowns: Q1 2015 Benchmarks for Residential, Commercial, and Utility-Scale Systems. NREL/TP-6A20-64746. Golden, CO: National Renewable Energy Laboratory. http://www.nrel.gov/docs/fy15osti/64746.pdf.

CSI (California Solar Initiative). 2018. “CSI Working Data Set.” Accessed May 10, 2018. http://www.californiadgstats.ca.gov/downloads.

DSIRE (Database of State Incentives for Renewables \& Efficiency). 2018. Accessed May 10, 2018. http://www.dsireusa.org/.

Enphase. 2018. Enphase quarterly presentations. Accessed May 20, 2018. http://investor.enphase.com/events.cfm?Year=2017.

Feldman, D., G. Barbose, R. Margolis, M. Bolinger, D. Chung, R. Fu, J. Seel, C. Davidson, N. Darghouth, and R. Wiser. 2015. Photovoltaic System Pricing Trends: Historical, Recent, and Near-Term Projections. NREL/PR-6A20-64898. Golden, CO: National Renewable Energy Laboratory. http://www.nrel.gov/docs/fy15osti/64898.pdf.

Feldman, D., B. Friedman, and R. Margolis. 2013. Financing, Overhead, and Profit: An InDepth Discussion of Costs Associated with Third-Party Financing of Residential and Commercial Photovoltaic Systems. NREL/TP-6A20-60401. Golden, CO: National Renewable Energy Laboratory. http://www.nrel.gov/docs/fy14osti/60401.pdf.

Feldman, D., Lowder, T. Lowder, and P. Schwabe. 2016. Terms, Trends, and Insights PV Project Finance in the United States, 2016. NREL/BR-6A20-66991. Golden, CO: National Renewable Energy Laboratory. http://www.nrel.gov/docs/fy16osti/66991.pdf. 
Fu, R., D. Chung, T. Lowder, D. Feldman, K. Ardani, and R. Margolis. 2016. U.S. Solar Photovoltaic System Cost Benchmark: Q1 2016. NREL/TP-6A20-66532. Golden, CO: National Renewable Energy Laboratory. http://www.nrel.gov/docs/fy16osti/66532.pdf.

Fu, R., T.L. James, D. Chung, D. Gagne, A. Lopez, and A. Dobos. 2015. "Economic Competitiveness of U.S. Utility-Scale Photovoltaic Systems in 2015: Regional Cost Modeling of Installed Cost $(\$ / W)$ and LCOE $(\$ / k W h)$." Presented at the IEEE 42nd Photovoltaic Specialist Conference, New Orleans, LA. http://www.nrel.gov/analysis/pdfs/Economic_Competitiveness_of_US_UtilityScale_Photovoltaics_System.pdf.

Go Solar CA (Go Solar California). 2018. "Currently Interconnected Data Set.” Accessed May 10, 2018. http://www.californiadgstats.ca.gov/downloads.

GTM Research. 2018. Q1 2018 Solar Executive Briefing. Boston: Greentech Media.

GTM Research and SEIA (Solar Energy Industries Association). 2018. U.S. Solar Market Insight Report, Q2 2018. Washington, D.C.: Solar Energy Industries Association.

NREL. 2018. NREL dialogues and interviews with solar industry collaborators. Golden, CO: National Renewable Energy Laboratory.

PVinsights. 2018. PVinsights database. Accessed May 20, 2017.

RSMeans, ed. 2016. RSMeans Building Construction Cost Data 2015, 73rd annual edition. Norwell, MA: RSMeans.

SolarEdge. 2018. SolarEdge quarterly presentations. Accessed May 20, 2018. http://investors.solaredge.com/phoenix.zhtml? $\mathrm{c}=253935 \& \mathrm{p}=$ irol-news\&nyo $=0$.

Sunrun. 2018. Sunrun quarterly presentations. Accessed May 20, 2018. http://investors.sunrun.com/phoenix.zhtml?c=254007\&p=irol-calendar.

Tesla. 2018. Tesla quarterly presentations. Accessed May 20, 2018. http://ir.tesla.com/eventsand-presentations.

Vivint Solar. 2018. Vivint Solar quarterly presentations. Accessed May 20, 2018. http://investors.vivintsolar.com/company/investors/events-andpresentations/presentations/default.aspx. 


\section{Appendix. PV System LCOE Benchmarks in 2018 USD}

Table 10. NREL LCOE Summary (2018 cents/kWh)

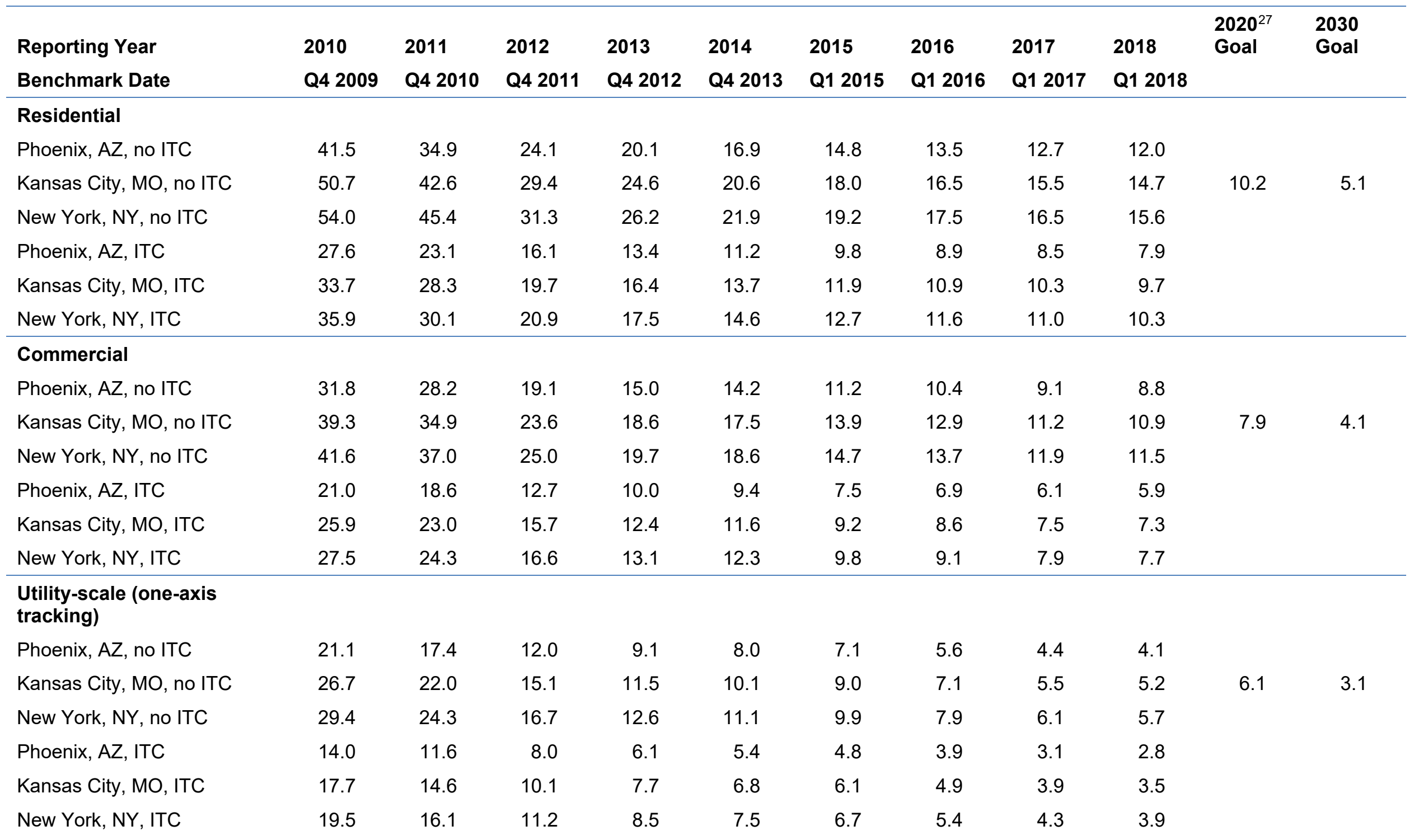

${ }^{27} 2020$ residential and commercial SETO goals are adjusted for inflation using the Consumer Price Index; the 2020 utility-scale goal was left unchanged, because wholesale prices were relatively flat, and in some cases declined, from 2010-2018. 
Utility-scale (fixed-tilt)

Phoenix, AZ, no ITC

Kansas City, MO, no ITC

New York, NY, no ITC

22.4

27.3

18.7

12.8

9.7
11.9
12.7
6.6
8.1
8.6

$\begin{array}{rr}8.8 & 8.3 \\ 10.7 & 10.1 \\ 11.5 & 10.7 \\ 6.0 & 5.6 \\ 7.3 & 6.8 \\ 7.8 & 7.2\end{array}$

6.7

4.9

4.8

29.2

22.9

15.6

8.1

6.0

5.8

Phoenix, AZ, ITC

14.9

16.7

8.6

6.4

6.2

Kansas City, MO, ITC

18.2

12.5

8.6

4.6

3.4

3.2

New York, NY, ITC

19.4

16.3

11.2

$5.5 \quad 4.2$

4.0

$\begin{array}{lll}5.9 & 4.5 & 4.2\end{array}$ 